\author{
UNIVERSIDADE DE SÃO PAULO \\ ESCOLA DE ENGENHARIA DE LORENA - EEL
}

RENATO DA SILVA TEIXEIRA

\title{
Avaliação do efeito de micro-organismos probióticos sobre Haemonchus contortus em ovinos
}


RENATO DA SILVA TEIXEIRA

\section{Avaliação do efeito de micro-organismos probióticos sobre Haemonchus contortus em ovinos}

Dissertação apresentada à Escola de Engenharia de Lorena da Universidade de São Paulo para a obtenção do título de Mestre em Ciências do Programa de Pós-Graduação em Biotecnologia Industrial na área de Microbiologia Aplicada.

Orientação: Prof. Dr. Ismael Maciel de Mancilha

Edição reimpressa e corrigida

Lorena - SP

Outubro, 2011 
AUTORIZO A REPRODUÇÃO E DIVULGAÇÃO TOTAL OU PARCIAL DESTE TRABALHO, POR QUALQUER MEIO CONVENCIONAL OU ELETRÔNICO, PARA FINS DE ESTUDO E PESQUISA, DESDE QUE CITADA A FONTE.

Catalogação na Publicação

Biblioteca "Cel. Luiz Sylvio Teixeira Leite"

Escola de Engenharia de Lorena da Universidade de São Paulo

Teixeira, Renato da Silva

Avaliação do efeito de micro-organismos probióticos sobre Haemonchus contortus em ovinos. / Renato da Silva Teixeira. - ed. reimpr., corr.- 2011.

79 p.: il.

Dissertação (Mestre em Ciências - Programa de Pós-Graduação em Biotecnologia Industrial na Área de Microbiologia Aplicada) - Escola de Engenharia de Lorena da Universidade de São Paulo. 2011.

Orientador: Ismael Maciel de Mancilha

1. Probióticos 2. Lactobacilos 3. Haemonchus contortus 4. Ovinos . I. Título

$$
663.1-\mathrm{CDU}
$$


Aos meus pais, Luiz e Marli. Com amor e carinho, me educaram; com muito esforço e incentivo, me deram à oportunidade de estudar. Pais, esta conquista também pertence a vocês. 



\section{AGRADECIMENTOS}

Primeiramente a DEUS, por me dar força, proteção e por iluminar e colocar em meu caminho pessoas maravilhosas, para os quais vão os meus sinceros agradecimentos a seguir.

Ao meu orientador, professor Dr. Ismael Maciel de Mancilha, pela confiança, atenção e principalmente pelos ensinamentos transmitidos, os quais contribuíram para meu amadurecimento profissional.

À minha família, em especial aos meus pais, ao meu irmão Renann, a minha tia Cida, as minhas avós Marcionila e Dilza e aos meus avôs que já se foram, por me transmitirem princípios e valores que foram fundamentais para minha formação pessoal.

À Krysleine (Krys), pelo companheirismo e amor dados constantemente, por me apoiar quando me via em dificuldades e por compreender, que às vezes, minha ausência era necessária para eu alcançar esta conquista.

Ao professor Dr. Carlos Alberto Sanches Pereira. "Carlinhos", muito mais que um mestre e amigo, te considero um "paizão", serei eternamente grato a confiança depositada em meu trabalho, as oportunidades e incentivos oferecidos, aos conselhos e cobranças que me fizeram crescer e por servir de modelo para minha vida profissional. Agradeço também por permitir minha presença no Lacon, para realização dos exames hematológicos e bioquímicos.

Ao meu grande amigo Ronie Cabral, pelas caronas nas viagens até Lorena, sou muito feliz em tê-lo como um irmão. Também agradeço sua mãe, Maria Aparecida Cabral (Dona Tida), por me hospedar em sua casa e me tratar como membro da família.

À minha amiga Priscila Filgueiras, pela confiança, incentivo e oportunidades oferecidas.

Ao amigo professor Dr. Mauro Sérgio Cruz Souza Lima, pelas sugestões dadas para melhoria do trabalho, pelos ensinamentos em bioestatística e por despertar em mim o gosto pelo estudo em Parasitologia.

Ao pesquisador científico José Roberto Pereira, do Laboratório de Sanidade Animal da Agência Paulista de Tecnologia dos Agronegócios (APTA) de Pindamonhangaba-SP, pelos exames parasitológicos.

Ao responsável da Fazenda Joamar, José Donizete de Souza Xavier, por ceder gentilmente os animais e o espaço para o experimento. Aos funcionários, Divanil César Rodrigues 
(Nil), Edson da Silva (Zinho) e Thalyta Baldim Xavier, por se dedicaram ao experimento. Sem o auxílio de vocês no manejo dos animais, o trabalho seria muito difícil.

Ao Conselho Nacional de Pesquisa (CNPq), pelo auxílio financeiro.

Aos membros da banca, pelas contribuições que enobreceram o meu trabalho. 


\section{BIOGRAFIA}

Renato da Silva Teixeira, filho de Luiz Cláudio Teixeira e Marli Lima da Silva Teixeira, nasceu em 28 de abril de 1987 na cidade de Volta Redonda - RJ.

Em 2008, conclui o curso de graduação em Ciências Biológicas no Centro Universitário Geraldo Di Biase (UGB, Volta Redonda - RJ), tendo desenvolvido atividades em nível de iniciação científica e monitoria, no Laboratório de Microbiologia, focando suas pesquisas sobre probióticos.

Em 2009, iniciou a Pós-Graduação em nível de Mestrado em Biotecnologia Industrial, na Escola de Engenharia de Lorena - USP, sob a orientação do Prof. Dr. Ismael Maciel de Mancilha.

Em janeiro de 2011, foi contratado pela Secretária de Educação do Estado do Rio de Janeiro para ocupar o cargo de professor em Biologia. Nesta mesma data foi contratado pelo Colégio do Instituto Batista Americano para lecionar a disciplina Parasitologia no Curso Técnico em Análises Clínicas, onde permanece até a presente data.

Em abril de 2011, conclui o curso de Pós-Graduação "Latu Sensu” em Análises Clínicas pelo Centro Universitário de Barra Mansa (UBM, Barra Mansa - RJ). 

"É melhor tentar e falhar, que se preocupar e ver a vida passar"; É melhor tentar, ainda que em vão, que se sentar fazendo nada até o final; Eu prefiro na chuva caminhar, que em dias tristes em casa me esconder; Prefiro ser feliz, embora louco, que em conformidade viver ..."

Martin Luther King 



\section{RESUMO}

TEIXEIRA, R. S. Avaliação do efeito de micro-organismos probióticos sobre Haemonchus contortus em ovinos. 2011. 79 p. Dissertação (Mestrado em Ciências) Escola de Engenharia de Lorena, Universidade de São Paulo, Lorena-SP, 2011.

A infecção por Haemonchus contortus é a principal parasitose que afeta a ovinocultura, provocando consideráveis perdas econômicas. Sua patogenia é caracterizada por uma intensa anemia, além de hipoproteinemia e reduções nos níveis séricos de ferro. Devido ao aumento da resistência desse parasito aos anti-helmínticos comumente encontrados no mercado, surge a necessidade de tratamentos alternativos, como por exemplo, o uso de produtos probióticos. Probióticos são alimentos funcionais que contém micro-organismos vivos, que ingeridos, com frequência e em doses adequadas trazem benefícios aos hospedeiros por meio de diferentes mecanismos de ação. Desta forma, o presente trabalho teve como objetivo avaliar o efeito de uma preparação probiótica constituída de diferentes espécies de Lactobacillus (L. casei ATCC 7469, L. plantarum ATCC 8014, L. fermentum ATCC 9338 e L. acidophilus ATCC 4536) na forma de "pool" sobre H. contortus em ovinos. Para tanto foram estudados 40 animais naturalmente infectados e distribuídos em 4 grupos e por 90 dias submetidos a diferentes tratamentos, a saber: Grupo A (controle): os animais não receberam nenhum tratamento, Grupo B os animais receberam em 3 dias por semana $\left(2^{\mathrm{a}}, 4^{\mathrm{a}}\right.$ e $6^{\mathrm{a}}$ feiras) uma dose de $10 \mathrm{~mL}$ da preparação probiótica, Grupo $\mathrm{C}$ os animais receberam, no dia 0 dose única de Diantel® $(1 \mathrm{~mL}$ para cada $10 \mathrm{Kg}$ de PV) e Grupo D os animais receberam, no dia 0, dose única de Diantel® $(1 \mathrm{~mL}$ para cada $10 \mathrm{Kg}$ de PV) e após 30 dias passaram a receber em 3 dias por semana $10 \mathrm{~mL}$ da preparação probiótica, sendo interrompido no $60^{\circ}$ dia. A cada 15 dias foram realizados exames parasitológicos para quantificação de OPG de fezes, hemograma completo, dosagem de proteínas e ferro. Os resultados demonstraram que os animais do Grupo B (probiótico) apresentaram uma eliminação de OPG de fezes significativamente menor $(p<0,05)$ em relação aos demais grupos com uma eficácia de ação máxima de 66,3\%, além dos animais se apresentarem em melhores condições fisiológicas. Maiores concentrações de hemoglobina, hematócrito e ferro também foram observadas nesse grupo, que podem ser explicadas pela ação imunomoduladora apresentada pelas espécies de Lactobacillus avaliadas, além de facilitar a absorção de nutrientes pelo animal hospedeiro. Em relação aos animais do Grupo C (Diantel®), após 45 dias ocorreu um aumento significativo $(\mathrm{p}<0,05)$ na contagem de OPG de fezes indicando uma maior atividade parasitária, levando a redução dos valores de hemoglobina e hematócrito. O uso do anti-helmíntico no Grupo D apresentou eficácia máxima de 90,3\% após 15 dias. A inclusão da preparação probiótica, na dieta dos animais deste grupo após 30 dias, não contribuiu para se evitar a reinfecção, possivelmente devido a sensibilidade das cepas utilizadas ao princípio ativo closantel, tendo sido evidenciada a necessidade de uma nova dosagem do anti-helmíntico após 60 dias, como indicado pelo fabricante.

Palavras-chave: Probióticos. Lactobacilos. Haemonchus contortus. Ovinos. 


\begin{abstract}
TEIXEIRA. R. S. Evaluation of the effects of probiotic microorganisms on Haemonchus contortus in ovines. 2011. 79 p. Dissertation (Master of Science) - Escola de Engenharia de Lorena, Universidade de São Paulo, Lorena-SP, 2011.

The infestation by Haemonchus contortus is the main parasitize that affects the ovine farms, causing a significantly economic loss. Its pathogenesis is characterized through an intense anemia, besides hypoproteinemia and blood iron level reduction. Due to the parasite resistance increasing to anti-helmintics usually found in the market, a need of an alternative treatment is evident, as example, the use of probiotics microorganisms. Probiotics are functional food that contains live microorganisms that when ingested in appropriate amount bring benefits to the hosts through different action mechanisms. Thus, this research had as purpose to study the effect of a probiotic preparation formed by a pool of Lactobacillus species (L. casei ATCC 7469, L. plantarum ATCC 8014, L. fermentum ATCC 9338 e L. acidophilus ATCC 4536) on H. contortus in ovines. Therefore, 40 naturally infected animals were distributed in 4 groups and during 90 days they were submitted to different treatments: Group A (control): the animals did not receive any treatment, Group B: The animals received 3 times a week $\left(2^{\circ}, 4^{\circ}, 6^{\circ}\right)$ a $10 \mathrm{ml}$ dose of the probiotic preparation, Group C: the animals received on 0 day, a Diantel single dose $(1 \mathrm{ml}$ $/ 10 \mathrm{~kg}$ of $\mathrm{LW})$ and in group D: the animals received on 0 day, a Diantel single dose $(1 \mathrm{ml}$ $110 \mathrm{~kg}$ of $\mathrm{LW}$ ) and after 30 days they started receiving 3 times a week $10 \mathrm{ml}$ of the probiotic preparation, ending at the $60^{\text {th }}$ day. In each fifteen days parasitological exams were realized to check the amount of EPG of feces, complete blood exam, protein and blood iron analysis. The results showed that the animals in group B (probiotic) had "EPG" of feces elimination significantly minor $(\mathrm{p} 0,05)$ related to the other groups with a efficacy of $66,3 \%$ besides, the animals presented better physiological conditions. An increasing of hemoglobin, hematocrit and blood iron level were also observed in this group, which can be explained by the immunemodulator action presented by the Lactobacillus species, which contribute to the nutrients absorption by the host animal. In relation to group $\mathrm{C}$ animals (Diantel), is was observed, after 45 days, a significantly increasing (p 0,05) in the EPG counting, resulting in a major parasitary activity, decreasing the hemoglobin and hematocrit values. The usage of anti-helmintic in group D showed a efficacy of $90,3 \%$ after 15 days. The probiotic preparation administered to the animals of group D did not contribute to avoid the re-infestation, probably due to the strains sensibility regarding to the active principle (closantel) of Diantel, being necessary another anti-helmintic dose administration after 60 days as indicated by the manufacturer.
\end{abstract}

Keywords: Probiotics. Lactobacillus. Haemonchus contortus. Ovines. 


\section{LISTA DE ILUSTRAÇÕES}

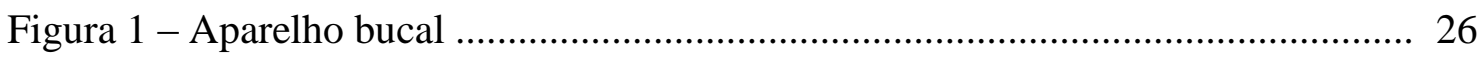

Figura 2 - Ciclo biológico do Haemonchus contortus ........................................... 28

Figura 3 - Punção venosa .......................................................................... 38

Figura 4 - Contagem relativa dos linfócitos dos animais submetidos a diferentes tratamentos

Figura 5 - Concentração de hemoglobina nos animais submetidos a diferentes tratamentos

Figura 6 - Valores da OPG e do hematócrito dos animais submetidos a diferentes tratamentos.

Figura 7 - Concentração de proteínas totais no sangue dos animais submetidos a diferentes tratamentos

Figura 8 - Concentração de albumina no sangue dos animais submetidos a diferentes tratamentos

Figura 9 - Concentração de globulina no sangue dos animais submetidos a diferentes tratamentos

Figura 10 - Concentração de ferro no sangue dos animais submetidos a diferentes tratamentos 


\section{LISTA DE TABELAS}

Tabela 1 - Principais micro-organismos utilizados em preparações probióticas ........ 19

Tabela 2 - Variáveis e níveis estudados ................................................................ 35

Tabela 3 - Experimentos realizados conforme o planejamento fatorial completo $2^{2}$.. 35

Tabela 4 - Características do Método Famacha ...................................................... 37

Tabela 5 - Valores médios \pm desvio padrão da contagem de OPG de fezes dos animais submetidos a diferentes tratamentos

Tabela 6 - Valores de eficácia de redução de OPG nas fezes de animais submetidos a diferentes tratamentos

Tabela 7 - Valores médios \pm desvio padrão da leucometria (Leucócitos $/ \mu \mathrm{L}$ ) dos animais submetidos a diferentes tratamentos

Tabela 8 - Valores médios \pm desvio padrão da contagem diferencial de células leucocitárias dos animais submetidos a diferentes tratamentos 46

Tabela 9 - Valores médios \pm desvio padrão da contagem de hemácias $\left(\mathrm{n}^{\circ} \times 10^{6} / \mu \mathrm{L}\right)$ dos animais submetidos a diferentes tratamentos 


\section{SUMÁRIO}

1 INTRODUÇÃO

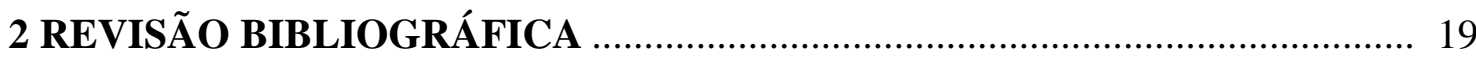

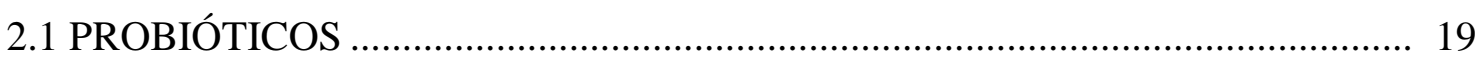

2.1.1 Probiótico na saúde animal ...................................................................... 21

2.1.2 Uso de probiótico como antiparasitário ......................................................... 23

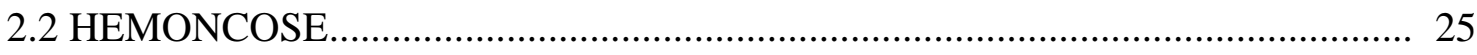

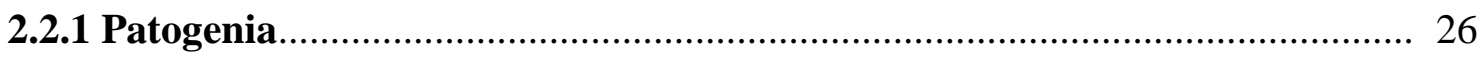

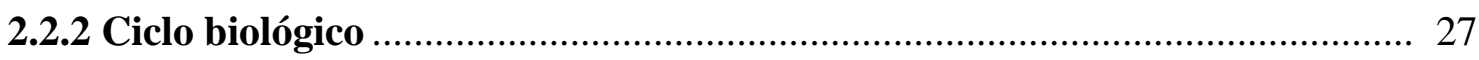

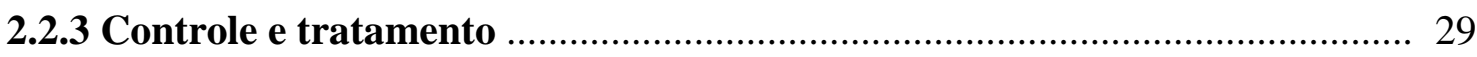

2.3 DROGAS ANTI-HELMÍNTICAS ………………………............................. 31

3 MATERIAL E MÉTODOS ……................................................................. 34

3.1 MICRO-ORGANISMOS E PREPARAÇÃO PROBIÓTICA.................................. 34

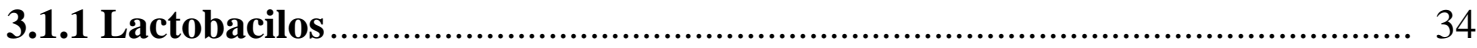

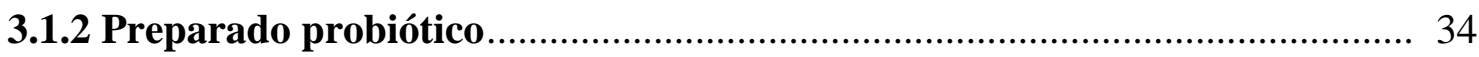

3.2 DELINEAMENTO EXPERIMENTAL ......................................................... 35

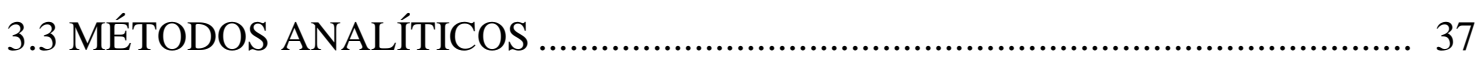

3.3.1 Exame parasitológico e coprocultura ……………………………………..... 37

3.3.2 Coleta sanguínea ………………………………………………….... 38

3.3.3 Exame do tecido hematopoético ………………….................................... 38

3.3.4 Dosagens de ferro e proteínas totais e frações................................................. 39

3.3.5 Exame para verificação do estado anêmico dos animais "in situ” ................ 39

3.4 ANÁLISES ESTATÍSTICAS........................................................................... 39

4 RESULTADOS E DISCUSSÃO.......................................................................... 41

4.1 AVALIAÇÃO DOS MICRO-ORGANISMOS PROBIÓTICOS SOBRE

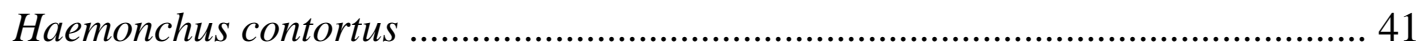

4.2 AVALIAÇÃO DO TECIDO HEMATOPOÉTICO …………………………….... 44

4.2.1 Leucograma …………………………………………………………. 44

4.2.2 Eritrograma ................................................................................. 49

4.3 NÍVEIS SÉRICOS DE PROTEÍNAS E FERRO ….............................................. 52

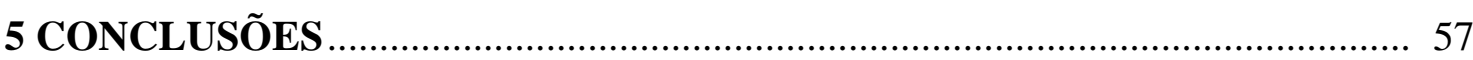

6 SUGESTÕES PARA TRABALHOS FUTUROS .............................................. 58

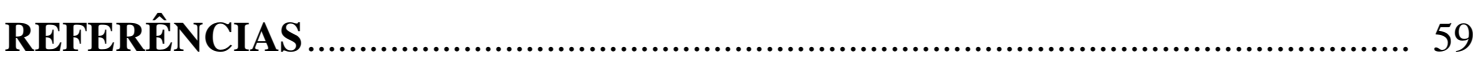




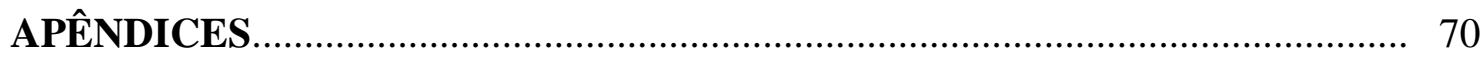




\section{INTRODUÇÃO}

A ovinocultura brasileira, antes voltada apenas para a produção de lã, passou por um difícil momento na década de 90, devido à utilização de materiais sintéticos na indústria têxtil internacional, porém, com o aumento do consumo de carne de cordeiros nos últimos dez anos, verifica-se o aumento do agronegócio de ovinos no país (NETO, 2007). O Brasil possui um efetivo de aproximadamente 17 milhões de cabeças (IBGE, 2010), mas apesar de apresentar um constante crescimento, este número ainda é muito discreto no cenário mundial representando apenas $1,7 \%$ do rebanho em todo o mundo. Calvette; Villwock (2007) afirmam que o mercado de ovinos no país é bastante promissor, uma vez que a demanda é maior que a oferta, mas que como em todo sistema de produção, a criação de ovinos possui alguns pontos de entrave importantes e que devem ser bem conhecidos e controlados para otimizar e tornar essa atividade viável.

A infecção por parasitos gastrointestinais é considerada por muitos o principal fator que afeta a ovinocultura e dentre eles Haemonchus contortus é o que mais se destaca (FERNANDES et al., 2004; AMARANTE, 2004; RISSI et al., 2010).

Haemonchus contortus é um nematóide da família Trichostrongylidae e agente etiológico da hemoncose. Essa doença é caracterizada por uma intensa anemia provocada pelos hábitos hematófagos do parasito, além disso, são observadas reduções nos níveis sanguíneos de proteínas e ferro. Essa patogenia gera consideráveis perdas econômicas como mortalidade elevada, reduções na taxa de conversão alimentar e consequentemente no crescimento dos animais afetados, má eficiência reprodutiva, baixa produção de lã e carne.

O tratamento geralmente é baseado pelo uso profilático e terapêutico de antihelmínticos, porém, tem sido registrados inúmeros casos de resistência (RAMOS et al., 2002; MELO, 2005; SCZESNY-MORAES et al., 2010). Esse fato tem levado a busca por métodos alternativos de controle, visando o não estabelecimento dos parasitos no hospedeiro. Entre eles pode-se citar a seleção de raças de animais naturalmente resistentes aos nematóides; suplementação de proteínas na dieta dos animais, uso de fitoterápicos, fungos nematófagos e método baseado no controle seletivo como o Famacha.

De acordo com Pereira (2007) animais tratados com probióticos podem ter suas condições sanitárias preservadas, e quando infectados por endoparasitos a evolução para a cura poderá ser mais rápida, quando comparados àqueles que receberam apenas tratamento 
homeopático ou alopático, reduzindo custos para o produtor e melhorando a qualidade de vida do animal.

Probióticos são considerados como suplemento alimentar natural, compostos de micro-organismos vivos, que possuem diversos efeitos benéficos a saúde do hospedeiro, e sendo constantemente utilizados visando ação reguladora da microbiota intestinal e manutenção do equilíbrio entre a microbiota normal e micro-organismos patogênicos no intestino, por meio de mecanismos antagônicos que podem ser mediados por exclusão competitiva por nutrientes ou por sítios de adesão e produção de compostos antimicrobianos como: ácidos orgânicos, peróxido de hidrogênio, diacetil e bacteriocinas. Além disso, os probióticos atuam diretamente na saúde do hospedeiro, estimulando a imunidade pelo aumento dos níveis de anticorpos e/ou atividade dos macrófagos, reduzindo o nível de colesterol e na atividade anticarcinogênica.

Desta forma, o presente trabalho teve como objetivo contribuir para o desenvolvimento de um método alternativo para o controle da hemoncose em ovinos, por meio da avaliação do efeito de micro-organismos probióticos como agentes antiparasitários sobre Haemonchus contortus. Especificamente avaliou-se a ação dos micro-organismos probióticos sobre a carga parasitária, o tecido hematopoético, bem como os níveis séricos de ferro e proteínas. 


\section{REVISÃO BIBLIOGRÁFICA}

\subsection{PROBIÓTICO}

Fuller (1989) definiu probiótico como um suplemento alimentar à base de microorganismos vivos, que afetam beneficamente o hospedeiro, promovendo o equilíbrio de sua microbiota intestinal. Entretanto, a definição internacionalmente aceita é que probiótico são micro-organismos vivos, que quando administrados em quantidades adequadas, conferem benefícios para saúde do hospedeiro (FAO/WHO, 2001; SANDERS, 2003).

Vários micro-organismos são utilizados em preparações probióticas (Tabela 1), com destaque para espécies dos gêneros Lactobacillus, Bifidobacterium, Pediococcus, Leuconostoc, Lactococcus, Enterococcus, Streptococcus, Bacillus e Escherichia e leveduras do gênero Saccharomyces (COPPOLA; TURNES, 2004; GUPTA; GARG, 2009).

Tabela 1 - Principais micro-organismos utilizados em preparações probióticas

\begin{tabular}{llll} 
Lactobacillus & Bifidobacterium & Outras bactérias ácido lácticas & Outros microrganismos \\
\hline L. acidophilus & B. adolescentis & Enterococcus faecalis & Bacillus cereus var. toyoi \\
L. amylovorus & B.animalis & Enterococcus faecium & Escherichia coli cepa nissle \\
L. casei & B. bifidum & Lactococcus lactis & Propionibacterium freudenreichii \\
L. crispatus & B. breve & Leuconstoc mesenteroides & Saccharomyces cerevisiae \\
L. delbrueckii subsp. & B. infantis & Pediococcus acidilactici & Saccharomyces boulardii \\
Bulgaricus & B. lactis & Sporolactobacillus inulinus & \\
L. gallinarum & B. longum & Streptococcus thermophilus & \\
L. gasseri & & & \\
L. johnssonii & & & \\
L. paracasei & & & \\
L. plantarum & & & \\
L. reuteri & & & \\
L. rhamnosus & & & \\
\hline Fonte: Coppolat & & & \\
\hline
\end{tabular}

Fonte: Coppola; Turnes, (2004).

Segundo Holzapfel; Schillinger (2002) para serem selecionados como probióticos, os micro-organismos devem manter a viabilidade celular durante o transporte e estocagem, serem resistentes a baixo $\mathrm{pH}$ e aos sais biliares, apresentar a capacidade de persistir no intestino, aderir no epitélio evitando a eliminação pelo peristaltismo, resistir a fagos, serem inócuos e para uma melhor eficácia, devem ser específicos dos hospedeiros. 
Os probióticos têm sido constantemente avaliados considerando sua ação reguladora da microbiota intestinal e manutenção do equilíbrio entre a microbiota benéfica e micro-organismos que se tornam patogênicos no intestino (NEUMANN et al., 2008). Mecanismos de ação como competição por sítios receptores na superfície intestinal, competição por nutrientes, excreção de compostos com atividade antimicrobiana, estimulação do sistema imunológico através do aumento dos níveis de anticorpos e o aumento da atividade dos macrófagos, e alteração do metabolismo microbiano através do aumento ou diminuição da atividade enzimática, tem sido relatados como propriedades que devem ser apresentadas pelos micro-organismos probióticos (DUGGAN; GANNON; WALKER, 2002; SAAD, 2006).

Os micro-organismos probióticos ocupam os sítios de ligações (receptores) na mucosa intestinal através da adesão e colonização, formando um tipo de barreira física, que evita a aderência dos micro-organismos indesejáveis. Assim, esses micro-organismos não conseguem se ligar a esses receptores e consequentemente são excluídos pela competição (LAVERMICOCCA et al., 2005).

Dentre os compostos antimicrobianos produzidos pelos micro-organismos probióticos, encontram-se os ácidos orgânicos como ácido láctico, peróxido de hidrogênio e bacteriocinas. Axe; Bailey (1995) acreditam que o efeito inibidor dos ácidos é principalmente causado pela penetração dessas moléculas na forma não dissociada, que são facilmente solúveis através da membrana celular, dos micro-organismos susceptíveis, para o citosol mais alcalino. Eventualmente, este fluxo contínuo interfere na permeabilidade da membrana e impede a fosforilação oxidativa a partir do sistema de transporte de elétrons. Este fluxo gera também o aumento de ânions intracelular, levando a acidificação do conteúdo celular, inibição da produção final do metabolismo e ATP, além de promover a perda de atividade de água, causando a morte da célula.

Segundo Cadenas (1989), o peróxido de hidrogênio causa stress oxidativo às células bacterianas podendo levar a alterações em componentes presentes na membrana celular como proteínas e lipídios, causando a morte da célula.

Diferentes mecanismos de ação das bacteriocinas têm sido propostos: destacandose alteração da atividade enzimática, inibição da germinação de esporos e formação de poros na membrana citoplasmática desfazendo sua permeabilidade seletiva (DEEGAN et al., 2006). A formação de poros é o principal mecanismo, e acontece inicialmente pela atração eletrostática entre os fosfolipídios aniônicos presentes na membrana da célula alvo e a carga positivas das bacteriocinas, sendo que esta interação permite que as bacteriocinas 
se insiram na bicamada fosfolipídica e se agregam lateralmente promovendo a formação dos poros. Consequentemente, a formação de poros resulta em ação sobre a permeabilidade da membrana, causando a perda de íons (principalmente íons fosfato, potássio e magnésio) e como consequência ocorre a dissipação da força próton-motriz, que está envolvida diretamente na síntese de ATP, fosforilação de proteínas e rotação dos flagelos. Na tentativa de manter a força próton-motriz, a célula afetada perde até $98 \%$ de ATP os quais são hidrolisados resultando em morte celular (BRUNO; MONTVILLE, 1994).

Segundo Coppola; Turnes (2004) inúmeras evidências demonstram que os probióticos têm efeito imunoestimulante em animais e no homem. Acredita-se que esse efeito pode estar relacionado à capacidade dos micro-organismos probióticos interagirem com as placas de Peyer e as células epiteliais intestinais, estimulando os linfócitos B produtores de IgA e a migração dos linfócitos T no intestino, favorecendo a atividade fagocítica dos macrófagos, o aumento da atividade das células NK (natural-killer) e o aumento nos níveis de citocinas e imunoglobulinas (SAAD, 2006).

\subsubsection{Probióticos na saúde animal}

Ávila et al. (2000) estudando a eficiência de um probiótico no controle de diarréia em bezerros, demonstraram que o número de casos de diarréia foi de $30 \%$ entre os animais tratados e $68,9 \%$ nos animais controle. Dentre os que receberam o probiótico e ainda sim apresentaram diarréia, foi observado um predomínio de Escherichia coli nas fezes e o isolamento de Lactobacillus e Streptococcus foi dificultado, entretanto, nos animais sem diarréias ocorreu o inverso, confirmando que as bactérias probióticas foram capazes de impedir a colonização intestinal pela Escherichia coli.

Ao avaliar o potencial probiótico de Lactobacillus fermentum AD1 sobre a saúde de cães, Strompfová et al. (2006) demonstraram um aumento significativo do nível sérico de proteínas nos animais que receberam o micro-organismo quando comparados aos animais do grupo controle, provavelmente devido ao melhor aproveitamento e absorção das proteínas na alimentação.

Estudando a eficácia da adição de um probiótico composto por Lactobacillus acidophillus, Bifidobacterium bifidum e Enterococus faecium, ao leite sem resíduos antimicrobianos e ao leite de vacas em tratamento de mastite, sobre a saúde de bezerras, Batista et al. (2008) observaram que a adição ao leite sem resíduo antimicrobiano, reduziu 
significativamente o número de diarréias nos animais em comparação aos que receberam o leite sem probiótico, o mesmo não ocorreu quando se utilizava leite de vacas tratadas contra mastite, demonstrando a possível sensibilidade dos micro-organismos probióticos aos compostos antimicrobianos ativos no leite. Os mecanismos apontados como causadores do efeito de redução de diarréias foram a exclusão competitiva e a estimulação do sistema imune das bezerras, uma vez que os agentes causadores de diarréia identificados nas fezes foram todos intracelulares: Cryptosporidium, Rotavírus e Coronavírus, e precisam invadir as microvilosidades intestinais para causarem danos.

Além dos efeitos benéficos a saúde do animal hospedeiro, os probióticos apresentam efeitos sobre o seu desempenho, favorecendo a conversão alimentar e ganho de peso (PINHEIRO; SOBRINHO; YAMAMOTO, 2007).

De acordo com Loddi et al. (2000) devido a essas propriedades, o uso dos probióticos, é uma alternativa para a substituição dos antibióticos, que a partir dos anos 50, passaram a ser utilizados como agentes terapêuticos e promotores de crescimento para animais domésticos. Entretanto, o uso dos antibióticos, tem sido restringido em diversos países, em virtude da possibilidade de desenvolvimento de resistência bacteriana cruzada e da emergente exigência dos países importadores de produtos livres de resíduos de antibióticos (UTIYAMA et al., 2006). Os prováveis substitutos ao uso de antibióticos como alternativa para os promotores de crescimento de animais domésticos, devem manter as ações benéficas dos antibióticos e minimizar as indesejáveis, como a resistência bacteriana. Por outro lado, Marteau; Salminen (1998) observaram que pode haver risco de transferência de genes entre o probiótico e a microbiota endógena, sendo assim, motivo de preocupação quando se considera o uso de preparações probióticas constituídas de microorganismos geneticamente modificados, pois estes poderiam abrigar genes de resistência a antibióticos.

Bernardeau; Vernoux; Gueguen (2002) utilizando Lactobacillus rhamnosus MA27/6B e L. acidophilus MA27/6R na dieta de camundongos jovens, relataram um aumento no ganho de peso de $28,9 \%$ e $31,7 \%$, respectivamente, quando comparados aos animais do grupo controle que só recebiam ração e água.

Silva et al. (2009) avaliando o efeito do simbiótico comercial BioSyn MOS® sobre o ganho de peso de cordeiros confinados, demonstraram que ao final dos 45 dias de experimento, os cordeiros do grupo controle tiveram um ganho de peso médio de 238 g/dia, enquanto que os tratados com o simbiótico apresentaram um ganho de $280 \mathrm{~g} / \mathrm{dia}$, representando um aumento significativo de 17,59\%. 
Administrando probiótico composto por Lactobacillus amylovorus e Enterococcus faecium em suínos, Ross et al. (2010) não observaram diferença de ganho de peso entre os grupos controle e o grupo tratado, porém, neste último os animais consumiram uma quantidade significativamente menor de alimentos, demonstrando que o uso de probiótico contribui para a melhoria da taxa de conversão alimentar.

\subsubsection{Uso de probiótico como antiparasitário}

Singer; Nash (2000) realizaram estudos em camundongos e verificaram que a microbiota normal exercia um papel de proteção contra a infecção por Giardia lamblia. Ao analisar os componentes desta microbiota, observaram a presença de lactobacilos e sugeriram então que o uso de probióticos também poderia exercer um efeito benéfico sobre as parasitoses.

Pérez et al. (2001) analisaram o efeito de sobrenadante de culturas de diferentes cepas de lactobacilos sobre o crescimento de trofozoítos de Giardia intestinalis, em culturas de células humanas do epitélio intestinal linha Caco-2, e observaram que apesar de ocorrer à aderência dos trofozoítos as células, estes não conseguiam se proliferar devido à redução do $\mathrm{pH}$ do meio, provavelmente relacionada à produção de ácidos orgânicos pelos lactobacilos.

Tierney et al. (2004) estudaram os efeitos de espécies de Lactobacillus, isolados de diferentes partes do trato gastrointestinal de frangos, sobre a invasão de Eimeria tenella, empregando como modelo experimental culturas de células MDBK. Os autores observaram que as espécies de Lactobacillus aderiam às células, causando efeito de inibição sobre a invasão da E. tenella por efeito de exclusão competitiva.

Administrando Zymomonas mobilis em camundongos infectados experimentalmente por Schistosoma mansoni, Santos et al. (2004) observaram que os animais que receberam a cultura bacteriana após a infecção, desenvolveram uma resposta imunológica mais eficiente em relação àqueles que receberam a cultura preventivamente, resultando em $61 \%$ e $24 \%$ de redução da contagem de vermes adultos, respectivamente, quando comparados ao grupo controle.

Ensaios in vivo, foram realizados por Humen et al. (2005), em roedores conhecidos como esquilos da Mongólia (Meriones unguiculatos) contaminados com Giardia intestinalis e tratados com Lactobacillus johnsonii La1. Após 14 dias de infecção, seis dos 
quatorze animais do grupo controle ainda apresentavam trofozoítos no intestino delgado enquanto os animais tratados não apresentavam infecção. Quanto à eliminação de antígenos fecais GSA65, nos animais do grupo controle os autores observaram que este antígeno nas fezes aumentou progressivamente a partir do $7^{\circ}$ dia de infecção até o $21^{\circ}$. Em contrapartida no grupo constituído dos animais tratados, apenas no $14^{\circ}$ dia foi detectado a presença deste antígeno em um animal. Além disso, nos animais tratados, a mucosa e a atividade enzimática intestinal se mantiveram íntegras diferentemente do grupo não tratado, demonstrando que o efeito antiparasitário do Lactobacillus johnsonii La1 foi devido à modulação do sistema imune do hospedeiro, tendo em vista a ausência de processos inflamatórios intestinais.

Em outro experimento, estudando o efeito do Enterococcus faecium SF68 sobre a melhora da resposta imune em camundongos infectados com Giardia intestinalis, Benyacoub et al. (2005) verificaram que a inclusão deste probiótico na dieta acarretou em quantidades significativamente menores de trofozoítos de Giardia no intestino e antígenos fecais em relação ao grupo controle. Esta redução foi atribuída ao aumento no percentual de linfócitos T-CD4 ${ }^{+}$e de anticorpos IgA da mucosa intestinal, provocada pelo probiótico.

Dalloul et al. (2005), trabalhando com frangos contaminados com Eimeria acervulina e alimentados com probiótico a base de lactobacilos, constataram que os animais tratados apresentaram redução de $14 \%$ na eliminação de oocistos nas fezes em comparação com o grupo controle. Observaram também um aumento dos níveis plasmáticos de Interferon-gama (INF- $\gamma$ ) e Interleucina-2 (IL-2) e aumento de INF- $\gamma$ na mucosa intestinal do grupo tratado, fato que pode estar diretamente relacionado com a redução do número de oocistos, devido à estimulação da imunidade celular, afetando o ciclo do parasito.

Utilizando ratos infectados com Trichinella spiralis, Randazzo; Costamagna (2005) demonstraram que a administração de Lactobacillus casei produziu efeito adverso sobre a penetração das larvas na mucosa intestinal, o número médio de parasitos adultos recuperados da mucosa foi de 81 no grupo controle e apenas 12 no grupo tratado.

Como modelo de estudo para alterações metabólicas provocadas por síndromes que provocam irritabilidade intestinal, Martin et al. (2006) utilizaram ratos infectados com Trichinella spiralis e posteriormente suplementados com Lactobacillus paracasei em sua dieta. Foi observado nos animais não tratados com a suplementação probiótica, um aumento nos níveis de creatina, lactato e taurina, associados à hipertrofia muscular do jejuno, por outro lado, os animais que receberam o tratamento normalizaram sua atividade 
muscular, seu metabolismo energético e apresentaram alterações nas concentrações plasmáticas de glutamina, metionina e lisina, que podem estar relacionadas à modulação da resposta imunológica.

Avaliando o efeito de micro-organismos probióticos sobre Eimeria spp em Rattus norvegicus, Pereira (2007) demonstrou que o preparado probiótico ministrado foi eficaz no sentido de promover a interrupção da eliminação de oocistos nas fezes dos animais, ganho de peso, melhor conversão alimentar e aumento do número de neutrófilos segmentados no tecido hematopoético dos animais.

Coutinho (2008), analisando o efeito de micro-organismos probióticos sobre Cryptosporidium parvum em camundongos C57BL/6 imunossuprimidos, observou que o uso preventivo do probiótico, gerou redução da eliminação de oocistos nas fezes e aumento do desempenho nutricional dos animais, devido à colonização da mucosa intestinal pelos lactobacilos que impediu a adesão pelas células parasitárias.

Para controle da infecção de Haemonchus contortus em ovinos, Gallina et al. (2009) utilizaram Saccharomyces cerevisae, Saccharomyces boulardii e Bacillus cereus var. toyoi. Dentre os micro-organismos estudados, apenas S. cerevisae demonstrou uma inibição no estabelecimento dos parasitos no abomaso, porém, em relação a quantificação das larvas obtidas na coprocultura, não foi observado diferença significativa em relação ao grupo controle.

Em estudo sobre o uso de probótico no combate a ancilostomíase canina, Coelho (2010) observou que os cães tratados com preparado probiótico composto de Lactobacillus acidophilus, L. delbruekii e L. plantarum, na forma de "pool”, apresentaram uma redução de $88,83 \%$ do número de ovos por grama de fezes (OPG), além da avaliação parasitológica, o mesmo grupo de animais também obteve melhorias em relação ao número de eritrócitos, concentração de hemoglobina e aumento do hematócrito, reduzindo a anemia provoca pelo nematóide.

\subsection{HEMONCOSE}

A hemoncose, uma das principais parasitoses que acometem ovinos, é uma doença causada pelo nematóide Haemonchus contortus, e ocorre preferencialmente em regiões tropicais e subtropicais. Taxonomicamente está espécie pertence ao filo Nematoda, Classe 
Secernentea, Ordem Strongylida, Família Trichostrongylidae e Gênero Haemonchus (CLIMENI; MONTEIRO; CICOTI, 2008).

Segundo Bricarello (2004), H. contortus é considerado o parasito que apresenta maior patogenicidade em pequenos ruminantes, localiza-se no abomaso de seus hospedeiros provocando anemia aguda devido ao hábito hematófago e destaca-se por apresentar resistência a anti-helmínticos.

De acordo com Amarante (2004) dos parasitas de ovinos, a espécie H. contortus encontra-se em primeiro lugar na ordem de prevalência em todo o território nacional. Em levantamento realizado por Rissi et al. (2010) sobre doenças de ovinos no Rio Grande do Sul, a hemoncose aparece no topo da lista das doenças infecciosas e parasitárias, confirmando a importância de seu estudo.

\subsubsection{Patogenia}

Conforme relatado por Radostitis et al. (2002) a patogenia relativa a hemoncose é caracterizada por uma anemia, que provoca perda considerável do volume sanguíneo na ordem de 0,05 $\mathrm{mL}$ por parasita por dia, de tal modo que um animal infectado por 5000 vermes de $H$. contortus, chega a perder $250 \mathrm{~mL}$ de sangue ao dia. Antes de atingir o estádio $\mathrm{L}_{5}, H$. contortus desenvolve a lanceta perfurante (Figura 1) que lhe permite a obtenção do sangue dos vasos da mucosa abomasal. Em decorrência do parasitismo ocorre diminuição das concentrações de proteínas séricas e do valor do hematócrito (URQUHART et al., 1998).

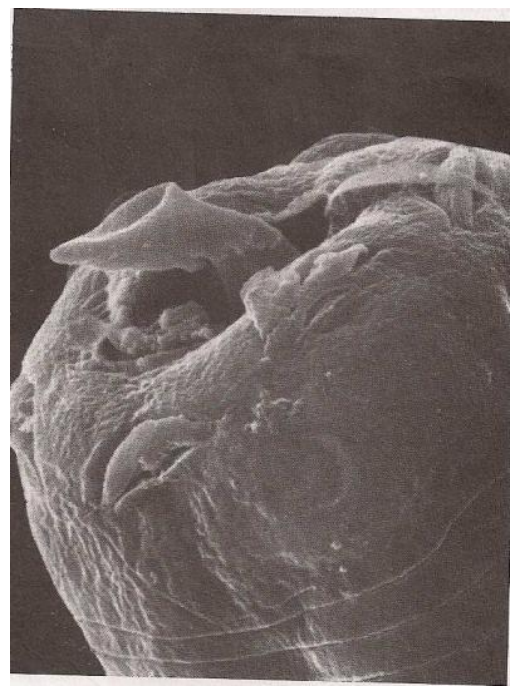

Figura 1 - Aparelho bucal

Fonte: URQUHART et al. (1998) 
A evolução da doença depende do número de parasitos e da habilidade do animal para compensar perdas agudas ou crônicas de proteínas plasmáticas, de hemoglobina e de outros constituintes do sangue. Nas infecções contínuas, o aumento na taxa de produção das hemácias provoca diminuição das reservas de ferro do organismo originando a deficiência desse elemento (STRAIN; STEAR, 2001).

Rosa (1996) descreve o edema submandibular ou papeira, como o sintoma que mais chama a atenção na hemoncose, esse edema é caracterizado por uma inflamação de aspecto mole como uma bolsa de água sob a pele, embaixo da mandíbula e vem acompanhada sempre de uma severa anemia, perda de peso e apetite, finalizando com desidratação e morte. Geralmente não se observa a existência de diarréia, as fezes apresentam-se um pouco mais secas que o normal e, o apetite fica inalterado até o último momento. Na fase aguda observa-se uma anemia moderada, gastroenterite catarral, desidratação, retardo de desenvolvimento e crescimento, diarréia líquida ou pastosa e pêlos arrepiados e sem brilho. Na fase crônica, período mais avançado dos sintomas, observa-se debilidade orgânica geral, edema submandibular, diminuição significativa na produção de leite e carne, emagrecimento, anemia acentuada e morte. As diarréias podem aparecer ou não em verminoses crônicas.

\subsubsection{Ciclo biológico}

O $H$. contortus apresenta um ciclo evolutivo direto, com um período de desenvolvimento no hospedeiro, denominado fase parasitária e outra no ambiente, denominada de vida livre (Figura 2). O ciclo de vida começa quando fêmeas adultas põem ovos, que são eliminados junto com as fezes do animal, cerca de 5.000 a 10.000 ovos/dia. No solo a eclosão desses ovos é controlada pela temperatura, sendo considerada ideal entre 18 a $26{ }^{\circ} \mathrm{C}$, e também umidade, que deve estar em torno de 80 a 100\% (ONYAH; ARSLAN, 2005). Uma vez liberada, as larvas de primeiro estádio $\left(\mathrm{L}_{1}\right)$ sofrerão mudas para formarem as larvas de segundo estádio $\left(\mathrm{L}_{2}\right)$, sendo essas duas formas denominadas de vida livre e se alimentam de bactérias e outros materiais orgânicos fecais. As larvas no estádio $\mathrm{L}_{2}$ por sua vez sofrerão uma nova muda formando as larvas de terceiro estádio $\left(\mathrm{L}_{3}\right)$, que não podem se alimentar devido à cutícula da $\mathrm{L}_{2}$ que fica retida, sobrevivendo assim dos nutrientes acumulados nos primeiros estádios. Em condições ideais, conforme mencionado, esse desenvolvimento leva aproximadamente 5 dias (BOWMAN, 1995). 
A infecção dos animais ocorre pela ingestão das larvas no estádio $L_{3}$ seguida de seu desencapsulamento no rúmen, após o que sofrem mais duas mudas tornando-se adultos imaturos $\left(\mathrm{L}_{5}\right)$. Antes mesmo de se tornarem larvas no estádio $\mathrm{L}_{5}$, estas irão desenvolver uma lanceta perfurante que lhes permitem a obtenção do sangue dos vasos da mucosa do abomaso, local de fixação do parasito. Quando adultos, movem-se livremente na superfície da mucosa. O período pré-patente é de duas a três semanas (URQUHART et al., 1998).

Conforme Urquhart et al. (1998) em épocas que são desfavoráveis para o desenvolvimento de larvas e adultos, como estação de seca e frio intenso, ocorre o fenômeno da hipobiose, onde os parasitos param seu desenvolvimento dentro do hospedeiro até mudar o clima, quando retomam às suas atividades.

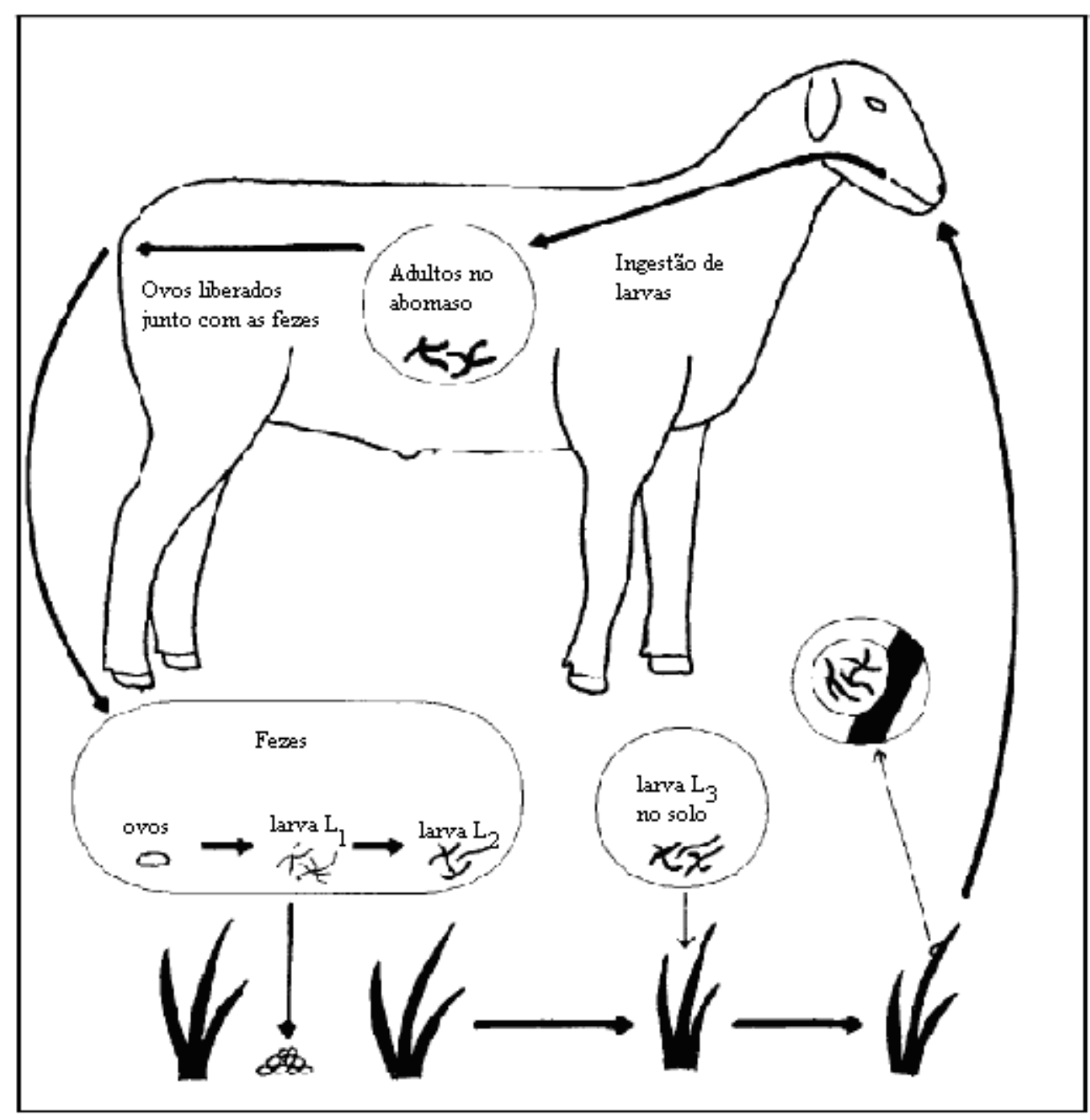

Figura 2 - Ciclo biológico do Haemonchus contortus

Fonte: Machen et al. (1998) 


\subsubsection{Controle e tratamento}

O controle das infecções por nematóides em ruminantes consiste basicamente no pastejo rotacionado e aplicação de anti-helmínticos. Entretanto, o uso adequado das pastagens muitas vezes não é considerado e o uso indiscriminado de drogas tem levado a um aumento da resistência parasitária (SANGSTER, 1999).

Baseados em estudos epidemiológicos e no fenômeno da hipobiose do H. contortus, Vieira (2008) recomenda que o rebanho deva ser medicado no início, no meio e no final da época de seca e uma quarta medicação em meados do período chuvoso. Esta vermifugação estratégica é uma medida preventiva de controle de verminose, considerando que as medicações do período seco devem controlar os parasitas em seus hospedeiros, que são praticamente os únicos locais de sobrevivência dos nematódeos nessa época do ano, enquanto que a medicação no período chuvoso destina-se a evitar surtos de parasitismo clínico. Como conseqüência, este procedimento reduz gradualmente a contaminação das pastagens pelas larvas infectantes $\left(\mathrm{L}_{3}\right)$, diminuindo assim a transmissão no período chuvoso seguinte e reduz a mortalidade no rebanho respectivamente.

Alternativas de manejo que diminuem a probabilidade do contato entre parasito e hospedeiro associado aos medicamentos, também contribuem para o controle da hemoncose. De acordo com Veríssimo; Catelli; Molento (2004) uma alternativa é o pastejo em conjunto ou alternado com outras espécies de animais que não são hospedeiros do $H$. contortus, como bovinos e equinos. Por outro lado, a desvantagem desse método é a possível ocorrência da população de parasitos comuns entre as espécies como Trichostrongylus axei e Cooperia spp. Rocha et al. (2008) afirmam que além da especificidade parasitária ao seu hospedeiro, a longevidade das formas de vida livre no ambiente também deve ser considerada, sendo assim, a alternância das espécies dos animais nas áreas de pastagens devem ocorrer em longos períodos, sendo o ideal a cada três a seis meses.

Segundo Amarante (2004) a habilidade dos ovinos expressarem imunidade contra os parasitas deve ser explorada ao máximo, tendo em mente que a mesma é regulada geneticamente e que é influenciada pela condição nutricional. A criação de raças ovinas resistentes aos parasitas associada com práticas de manejo e com a suplementação de alimento de qualidade (com nível elevado de proteína), especialmente para os cordeiros e as ovelhas no periparto, pode permitir uma situação de equilíbrio na relação parasita $\mathrm{x}$ hospedeiro. 
Outras formas de controle também vêm sendo estudadas, visando à redução da dependência de drogas anti-helmínticas e consequentemente da resistência parasitária aos mesmos (VIEIRA, 2008).

As plantas com atividade antiparasitária podem atuar diretamente sobre larvas infectantes $\left(\mathrm{L}_{3}\right)$ e parasitas adultos, com a diminuição da fecundidade das fêmeas ou indiretamente, aumentando o aproveitamento protéico da dieta pelo hospedeiro, melhorando a resposta imune deste contra os parasitos (JACKSON; MILLER, 2006).

Oliveira et al. (1997) obtiveram uma redução da carga parasitária em caprinos de 57,1\% para Haemonchus sp., 70,4\% para Oesophagostomum sp., 65,4\% para Trichostrongylus sp. e de 59,5\% para Cooperia sp., quando era administraram durante 25 dias folhas de bananeira.

O tratamento de ovinos infectados experimentalmente com larvas de $H$. contortus e Trichostrongylus colubriformis utilizando-se dose única do extrato hidroalcoólico da planta Fumaria parviflora, na dose de $183 \mathrm{mg} / \mathrm{kg}$ PV, resultou em $100 \%$ de redução no OPG e 78,2 e $88,8 \%$ de adultos de $H$. contortus e $T$. colubriformis, respectivamente, treze dias após o tratamento (HORDEGEN et al., 2003).

Ademola; Fagbemi; Idowu (2004) observaram redução de 88,8\% no OPG de nematódeos gastrintestinais de ovinos tratados por via oral com o extrato etanólico da casca de Khaya senegalensis (mogno africano) na dose de $500 \mathrm{mg} / \mathrm{kg}$ PV.

Maciel et al. (2006) avaliando o extrato etanólico das sementes de Melia azedarach (lírio) no tratamento de coproculturas, obtiveram a inibição de $100 \%$ da eclosão de ovos de H. contortus. O efeito foi atribuído a taninos condensados, triterpenos e alcalóides presentes na planta.

Os fungos nematófagos vivem na matéria orgânica do solo, onde desenvolvem relações parasíticas ou predatórias com os nematóides, e são classificados como ovicidas, endoparasitas e predadores. A forma mais prática de se fornecer esses fungos aos animais é pela administração oral. Após passar pelo trato gastrintestinal e ser eliminado com as fezes no meio ambiente, o fungo coloniza o bolo fecal, estabelece contato com as larvas eclodidas, penetram na cutícula e digerem os tecidos internos, levando-as à morte (GIROTTO et al., 2008).

Trabalhando com esporos do fungo Duddingtonia flagrans misturados à ração, PEÑA et al. (2002) obtiveram uma redução de 90\% do número larvas de Haemonchus contortus em fezes de caprinos, quando estes recebiam durante 7 dias uma dose diária de 500 esporos. 
O método seletivo Famacha, desenvolvido na África do Sul, consiste em classificar o estado anêmico do animal em cinco graus, baseado na avaliação da coloração da conjuntiva ocular que está significativamente correlacionada com o hematócrito. No método Famacha, apenas os animais que apresentam anemia clínica (Categoria 3, 4 e 5), recebem tratamento anti-helmíntico, desta forma, diminui o desenvolvimento da resistência (MOLENTO et al., 2004).

\subsection{DROGAS ANTI-HELMÍNTICAS}

Vários produtos anti-helmínticos vem sendo utilizados no tratamento de nematóides, tendo como princípio ativo benzimidazóis, avermectinas, imidazotiazóis e salicilanilidas, sendo este último amplamente utilizado contra Haemonchus spp. (BORGES, 2003).

Os benzimidazóis se conjugam com a tubulina, que é uma proteína estrutural, bloqueando sua polimerização e consequentemente impedindo a formação dos microtúbulos. Isto danifica as funções de integridade e transporte das células dependentes desta estrutura, interferindo nos neurotransmissores, na absorção de nutrientes, na divisão e na organização celular, levando o parasito à morte (SPINOSA; GÓRNIAK; BERNARDI, 2006).

As avermectinas são responsáveis por causar uma hiperpolarização da musculatura dos nematódeos, abrindo irreversivelmente os canais de cloro, provocando o aumento da liberação do neurotransmissor ácido gama-aminobutírico (GABA) acarretando em aumento da conjugação do GABA com seus receptores pós-sinápticos, tendo como consequência a paralisia dos músculos, principalmente do esôfago o que impossibilita a alimentação do parasito (MARTIN, 1997).

A atividade anti-helmíntica dos imidazotiazóis consiste em provocar uma paralisia espástica nos nematódeos, determinando uma contração muscular estável, o que facilita a eliminação do parasito (KÖHLER, 2001).

As salicilanilidas agem interferindo na produção de ATP nos parasitos, desacoplando as reações da fosforilação oxidativa mitocondrial. Segundo Swan (1999), o closantel representa a droga mais importante do grupo, sendo extensivamente usada no controle da infecção por Haemonchus contortus, Fasciola hepatica e Oestrus ovis em ovinos. 
Estudos realizados por Lacerda et al. (2009) sobre as vias de aplicação (oral e intramuscular) do closantel no controle de helmintos gastrintestinais em ovinos, demonstraram que apesar de não haver diferença significativa entre as formas de aplicação, a administração por via oral possibilitou um maior controle apresentando $96 \%$ de eficácia, enquanto que por via intramuscular a eficácia foi de $73 \%$.

Hennessy; Ali (1997) destacaram que a redução no consumo de alimentos antes da administração do closantel é de extrema importância, uma vez que, a diminuição do fluxo digestório prolonga o tempo de permanência do anti-helmíntico no trato gastrintestinal, aumentando sua absorção. Desta forma, os autores recomendaram jejum aos animais antes da administração de closantel. Após administração, o closantel entra na corrente sanguínea e se liga fortemente a albumina sérica, isso resulta no prolongamento dos níveis plasmáticos e da eficácia da droga, principalmente nos parasitos hematófagos, como o Haemonchus contortus (ROTHWELL; SANGSTER, 1997).

Ao administrarem closantel marcado radioativamente com carbono-14, Michiels; Meuldermans; Heykants (1987), puderam determinar que a concentração máxima alcançada pela droga no plasma sanguíneo é de $48 \mu \mathrm{g} / \mathrm{mL}$, obtida 24 horas após a administração. Demonstraram ainda que sua meia-vida é de aproximadamente 2 a 3 semanas, o que possivelmente está relacionada com sua ligação a albumina, que apresenta uma meia-vida de 20 dias. Decorridos 56 dias da administração, os autores ainda encontraram resíduos da droga no plasma na concentração de $8,60 \mu \mathrm{g} / \mathrm{mL}$.

A intoxicação por closantel em animais ocorre quando o produto é utilizado em sobredosagem, podendo provocar apatia, depressão acentuada, cólica, fraqueza dos membros, decúbito lateral, cegueira, alterações nervosas associados a status spongiosus (degeneração esponjosa) e até mesmo a morte (FURLAN et al., 2009). Segundo Cadioli et al. (2008) a dose de segurança varia entre 5 a $10 \mathrm{mg} / \mathrm{Kg}$ de peso vivo do animal.

Segundo Melo; Bevilaqua (2005) o aparecimento de cepas de nematóides resistentes aos anti-helmínticos pode ser explicado pela teoria da evolução, que tem como ponto básico a seleção natural, ou seja, os indivíduos mais adaptados sobrevivem e se reproduzem. Desta forma, Geary; Sangster; Thompson (1999) afirmaram que o fator mais importante para a resistência é a diversidade genética da espécie, onde aqueles que carreiam genes que reduzem a susceptibilidade a uma droga serão selecionados.

Em estudo realizado por Prichard (2001), verificou-se que Haemonchus contortus tem uma taxa de mutação do DNA mitocondrial dez vezes maior que nos vertebrados e o DNA nuclear é extremamente diverso, demonstrando a grande variabilidade genética deste 
parasito, que juntamente com a alta prolificidade da espécie, onde as fêmeas podem eliminar mais que 10.000 ovos por dia, potencializam a disseminação da resistência.

Conforme Wolstenholme et al. (2004), os mecanismos de resistência aos antihelmínticos podem ser específicos ou inespecíficos, sendo que o primeiro estão associados à ação da droga anti-helmíntica, enquanto os outros se referem a alterações no receptor da droga ou na modulação da concentração do fármaco.

A resistência aos benzimidazóis, por exemplo, tem sido associada com modificações relacionadas à tubulina, onde ocorre uma mutação que causa a troca do aminoácido fenilanina pela tirosina na posição 200 do gene da ß-tubulina, isso acarreta na diminuição dos sítios de alta afinidade à droga nas subunidades protéicas dos microtúbulos (KWA; KOOYMAN; BOERSEMA, 1993), em relação aos imidazotiazóis, a resistência ocorre devido à alteração farmacológica dos receptores de acetilcolina (SANGSTER, 1999). 


\section{MATERIAL E MÉTODOS}

O presente trabalho foi desenvolvido nas instalações da Fazenda Joamar em Pindamonhangaba-SP, no Laboratório de Sanidade Animal da Agência Paulista de Tecnologia dos Agronegócios (APTA) de Pindamonhangaba-SP, no Laboratório de Análises Clínicas Lacon em Volta Redonda-RJ e no Laboratório de Probióticos do DEBIQ/EEL-USP.

\subsection{MICRO-ORGANISMOS E PREPARAÇÃO PROBIÓTICA}

\subsubsection{Lactobacilos}

No presente trabalho foram utilizados para a formulação da preparação probiótica, quatro cepas de lactobacilos: Lactobacillus casei ATCC 7469, L. plantarum ATCC 8014, L. fementum ATCC 9338 e L. acidophilus ATCC 4536, que se encontram mantidas sob congelamento a $-20^{\circ} \mathrm{C}$ em Caldo MRS (De Mann, Rogosa e Sharpe) contendo $40 \%$ de glicerol (PEREIRA, 2001).

\subsubsection{Preparado probiótico}

Para ativação, as culturas foram descongeladas a temperatura ambiente e repicadas três vezes consecutivas em caldo MRS esterilizado a $121^{\circ} \mathrm{C} / 15 \mathrm{~min}$. e incubadas a $37^{\circ} \mathrm{C}$ por 24 à 48 horas (BORIS et al., 1997).

Para a formulação da preparação probiótica, as respectivas cepas de Lactobacillus foram individualmente ativadas por três vezes consecutivas em caldo MRS, sendo do último repique retirada uma alíquota de $2 \mathrm{~mL}$ de cada cultura, a qual foi individualmente transferida para frascos Erlenmyer contendo $200 \mathrm{ml}$ de caldo MRS esterilizado a $121^{\circ} \mathrm{C} / 15$ min., seguido de incubação a $37^{\circ} \mathrm{C}$ por 18 horas. Após este período os conteúdos dos 4 frascos foram juntados formando assim o "pool" de lactobacilos, contendo aproximadamente $10^{10} \mathrm{UFC} / \mathrm{mL}$ (PEREIRA, 2007). Este "pool" de micro-organismos foi 
preparado a cada sete dias e armazenado a $5{ }^{\circ} \mathrm{C}$ até o momento da administração aos animais.

\subsection{DELINEAMENTO EXPERIMENTAL}

No presente trabalho, com duração de 90 dias, foram utilizados 40 ovinos da raça Santa Inês, fêmeas com idades entre 2 a 4 anos, naturalmente infectados com Haemonchus contortus, devidamente confirmado pela presença de ovos e larvas nas fezes. Durante o período diurno, os animais foram mantidos em piquetes no regime de pastagem natural e, no final da tarde encaminhados ao curral, recebendo água e volumoso composto de capim elefante, ad libitum.

Para realização do experimento, foi empregada a metodologia do planejamento fatorial, onde foram avaliados dois fatores: preparação probiótica e um anti-helmíntico comercial Diantel ${ }^{\circledR}$ (Closantel 10\%). Cada variável foi avaliada em dois níveis de acordo com um planejamento fatorial completo $2^{2}$ (NETO; SCARMINIO; BRUNS, 2010), conforme apresentado nas Tabelas 2 e 3.

Tabela 2 - Variáveis e níveis estudados

\begin{tabular}{cccc}
\hline Variáveis & Variáveis & \multicolumn{2}{c}{ Níveis } \\
\cline { 3 - 4 } Independetes & Codificadas & (Baixo) -1 & (Alto) +1 \\
\hline $\begin{array}{c}\text { Preparado } \\
\text { probiótico }\end{array}$ & $\mathrm{X}_{1}$ & 0 & $\begin{array}{c}\text { "pool" contendo aproximadamente } \\
10^{10} \mathrm{UFC} / \mathrm{mL}\end{array}$ \\
Diantel@ & $\mathrm{X}_{2}$ & 0 & $1 \mathrm{~mL}$ para cada $10 \mathrm{Kg}$ de peso vivo \\
\hline
\end{tabular}

Tabela 3 - Experimentos realizados conforme o planejamento fatorial completo $2^{2}$

\begin{tabular}{ccc}
\hline Experimentos & $\begin{array}{c}\left(\mathrm{X}_{1}\right) \text { Preparado } \\
\text { probiótico }\end{array}$ & $\begin{array}{c}\left(\mathrm{X}_{2}\right) \text { Diantel } \\
(\text { Closantel } 10 \%)\end{array}$ \\
\hline Grupo A & -1 & -1 \\
Grupo B & +1 & -1 \\
Grupo C & -1 & +1 \\
Grupo D & +1 & +1 \\
\hline
\end{tabular}


Os animais foram distribuídos aleatoriamente em 4 grupos experimentais constituídos de 10 animais cada e submetidos aos seguintes tratamentos:

Grupo A: os animais não receberam nenhum tratamento durante o período do experimento (controle negativo).

Grupo B: os animais receberam em três dias da semana (segunda, quarta e sextafeira) $10 \mathrm{~mL}$ da preparação probiótica durante o período do experimento (efeito probiótico).

Grupo C: os animais receberam, no dia 0 dose única de $1 \mathrm{~mL}$ de Diantel® para cada $10 \mathrm{Kg}$ de peso vivo (efeito anti-helmíntico).

Grupo D: os animais receberam, no dia 0, dose única de $1 \mathrm{~mL}$ de Diantel® para cada $10 \mathrm{Kg}$ de peso vivo e após 30 dias passaram a receber em três dias da semana (segunda, quarta e sexta-feira) $10 \mathrm{~mL}$ da preparação probiótica, sendo interrompido no $60^{\circ}$ dia.

A preparação probiótica e o anti-helmíntico (Diantel®) foram administrados por via oral com auxílio de seringa descartável, introduzida diretamente na boca dos animais. Os animais que receberam Diantel® ficaram em jejum por no mínimo 12 horas.

A cada 15 dias, os animais, tiveram suas fezes coletadas e submetidas ao exame parasitológico para se proceder a contagem de ovos da família Trichostrongylidae por grama de fezes (OPG de fezes), por meio da técnica McMaster (1939) e a coprocultura para obtenção de larvas $\mathrm{L}_{3}$ e identificação do gênero, em conformidade com o método de Roberts e O’Sullivan (1950).

No mesmo período amostras de sangue foram coletadas para realização do hemograma completo, dosagem de ferro e proteínas, além disso, foi realizada a avaliação da coloração da mucosa conjuntiva ocular, para determinar o grau de anemia "in situ" pelo método Famacha descrito por Van Wik; Bath (2002), conforme apresentado na Tabela 4, sendo o tratamento interrompido quando os animais atingiram a categoria 4 ou 5 . 
Tabela 4 - Características do Método Famacha

\begin{tabular}{clccc}
\hline Categorias & Coloração da Conjuntiva* & Hematócrito (\%) & Conduta Clínica*** \\
\hline 1 & Vermelho robusto & 30 & Não vermifugar \\
2 & Vermelho rosado & 25 & Não vermifugar \\
3 & Rosa & 20 & Vermifugar \\
4 & Rosa pálida & & & Vermifugar \\
5 & Branco & & 15 & Vermifugar \\
\hline
\end{tabular}

* O avaliador deve ser treinado para estimar corretamente a coloração e evitar a divergência de interpretação no momento do exame clínico.

** A indicação do tratamento antiparasitário no cartão é baseada unicamente na coloração da conjuntiva.

Fonte: Molento et al. (2004)

\subsection{MÉTODOS ANALÍTICOS}

\subsubsection{Exame parasitológico e coprocultura}

As fezes dos animais foram coletadas diretamente da ampola retal e processadas pela técnica de McMaster, onde $4 \mathrm{~g}$ de fezes foram diluídas com $56 \mathrm{~mL}$ de solução saturada de cloreto de sódio 30 a 35\% (densidade 1.120 a 1.200) em Becker com capacidade de $100 \mathrm{~mL}$. Em seguida a câmara de McMaster foi preenchida com esta suspensão para proceder à análise por microscopia óptica (Nikon) em aumento de 100x. O valor encontrado nos dois campos da câmara foi divido por dois para obtenção de uma média e multiplicado pelo fator 100 para a obtenção do OPG de fezes, para fezes semidiarréicas e diarréicas o fator utilizado foram 200 e 600 respectivamente (NICIURA et al., 2009).

Para a coprocultura, as fezes foram depositadas em um recipiente de vidro e tampadas com uma placa de Petri, sendo borrifadas com água para aumentar a umidade, seguido de cultivo à temperatura ambiente por 10 dias. Transcorrido o tempo de cultivo, o frasco de vidro teve seu volume completado com água e, para recuperação das larvas, frasco e placa foram invertidos bruscamente, em seguida a placa de Petri também foi preenchida com água, após 4 horas seu conteúdo foi recolhido com pipeta, acondicionado em tubo de ensaio identificado e armazenado em geladeira por 3 horas para a decantação 
das larvas. Posteriormente, o sobrenadante foi removido e o sedimento analisado em microscopia óptica com aumento de 400x (NICIURA et al., 2009).

\subsubsection{Coleta sanguínea}

A coleta de sangue, foi realizada com auxílio de uma seringa descartável por meio de punção venosa na veia jugular (Figura 3), sendo $4 \mathrm{~mL}$ transferidos para tubo de ensaio contendo EDTA como anticoagulante e em seguida homogeneizado, para realização do hemograma. O restante da amostra $(6 \mathrm{~mL})$, foi transferido para tubo de ensaio seco e após coagulação do sangue, foi centrifugado por 600 x $g$ por 10 min. para obtenção do soro, utilizado nas dosagens bioquímica de ferro e proteínas totais e frações.

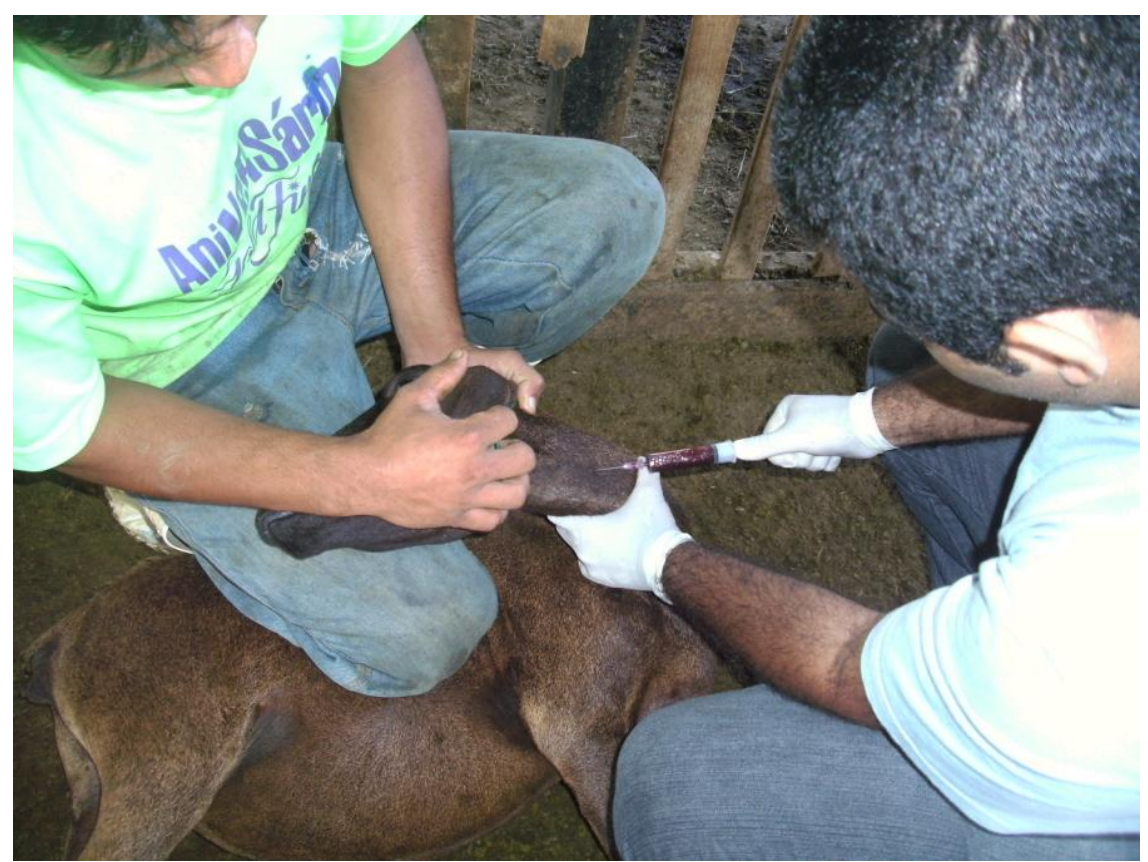

Figura 3 - Punção venosa

\subsubsection{Exame do tecido hematopoético}

Após a coleta, com auxílio de um esfregaço em lâmina com as bordas cortadas, foi confeccionado filme sanguíneo que em seguida foi corado pelo método de Leishman (BAIN, 1998). 
O hemograma foi realizado por meio de contador automático Cell-Dyn 3500, da marca Abbott. As contagens diferenciais dos leucócitos foram confirmadas, analisando-se os filmes sanguíneos, com auxílio do microscópio óptico em objetiva de 100x (Nikon).

\subsubsection{Dosagens de ferro e proteínas totais e frações}

Após a coleta de sangue e obtenção do soro, o mesmo foi aliquotado em tubo de soroteca e transferido para o analisador bioquímico Metrolab 2300, da marca Wiener lab. A dosagem de ferro, proteína total e albumina foram realizadas segundo as metodologias de Goodwin, biureto, e verde de bomocresol, respectivamente. A concentração de globulina foi determinada pela diferença entre a concentração de proteína total e a concentração de albumina conforme proposto pelo fabricante (Wiener lab).

\subsubsection{Exame para verificação do estado anêmico dos animais “in situ”}

A inspeção da mucosa conjuntiva ocular foi realizada em triplicata por técnicos devidamente treinados, onde compararam diferentes tonalidades, de vermelho-rosado até branco pálido, da conjuntiva com o cartão guia FAMACHA@. No cartão as tonalidades estão representadas com números de 1 a 5 que determinam o grau de anemia dos animais, onde quanto maior o grau Famacha, pior o estado anêmico. Os animais que atingiram um estado anêmico correspondente a categoria 4 ou 5, pele teste Famacha foram tratados com anti-helmíntico Diantel® na dose de $1 \mathrm{~mL}$ para cada $10 \mathrm{Kg}$ de peso vivo e excluídos do experimento (Van WYK; BATH, 2002).

\subsection{ANÁLISES ESTATÍSTICAS}

Os resultados foram analisados estatisticamente pelos testes ANOVA e Dunnet para verificar as diferenças entre os tratamentos. Para avaliar a correlação entre a contagem de OPG de fezes e o percentual de hematócrito, foi utilizada a correlação de Pearson. Estes testes foram realizados utilizando os softwares Excel e BioEstat 5.0. Também foi 
determinado a eficácia de cada tratamento conforme metodologia proposta por Niciura et al. (2009) empregando-se a seguinte fórmula:

$$
\% \text { Eficácia }=\frac{\text { Média } O P G_{\text {controle }}-\text { Média } O P G_{\text {tratamento }}}{\text { Média } O P G_{\text {controle }}} \times 100
$$




\section{RESULTADOS E DISCUSSÃO}

\subsection{AVALIAÇÃO DO EFEITO DE MICRO-ORGANISMOS PROBIÓTICOS SOBRE Haemonchus contortus}

No presente trabalho os ovinos foram distribuídos em 4 grupos no sentido de se verificar o efeito de micro-organismos probióticos, bem como do vermífugo Diantel® sobre Haemonchus contortus, cujos resultados, referentes a OPG de fezes, encontram-se apresentados na Tabela 5 (Apêndice A).

Verifica-se que os animais do grupo B (probiótico) apresentaram ao longo do experimento contagens de OPG inferiores aos do grupo C (Diantel $\left.{ }^{\circledR}\right)$, sendo esta diferença estatisticamente significativa ( $\mathrm{p}<0,05)$, através do teste ANOVA. Nota-se ainda que os animais do grupo B também apresentaram contagens de OPG inferiores ao grupo A (controle), porém não significativa ( $p>0,05)$. Observa-se também que a contagem de OPG no grupo B, após 90 dias de experimento, manteve-se em níveis constantes demonstrando, desta forma, que o "pool” de micro-organismos probióticos apesar de não apresentar uma ação direta sobre $H$. contortus, foi capaz de manter o equilíbrio entre parasito e hospedeiro.

Tabela 5 - Valores médios \pm desvio padrão da contagem de OPG de fezes nos animais submetidos a diferentes tratamentos

\begin{tabular}{cccccccc}
\hline & \multicolumn{7}{c}{ Tempo de Experimento (dias) } \\
\cline { 2 - 8 } Grupos & 0 & 15 & 30 & 45 & 60 & 75 & 90 \\
\hline \multirow{2}{*}{$\mathrm{A}$} & 930 & 1030 & 2140 & 2490 & 1163 & 1063 & 1257 \\
& \pm 819 & \pm 1226 & \pm 3484 & \pm 5528 & \pm 1363 & \pm 701 & \pm 1465 \\
& 744 & 556 & 722 & 1263 & 788 & 738 & 763 \\
$\mathrm{~B}$ & \pm 693 & \pm 450 & \pm 533 & \pm 1449 & \pm 588 & \pm 494 & \pm 560 \\
& 822 & 633 & 900 & $\mathbf{3 9 7 1}$ & $\mathbf{4 7 5 0}$ & $\mathbf{4 8 8 6}$ & $\mathbf{6 0 0 0}$ \\
$\mathrm{C}$ & \pm 822 & \pm 710 & \pm 694 & \pm 3997 & \pm 4772 & \pm 5013 & \pm 9193 \\
& 775 & 100 & 457 & 1643 & $\mathbf{3 3 7 5}$ & $\mathbf{3 2 8 8}$ & $\mathbf{3 3 7 5}$ \\
$\mathrm{D}$ & \pm 824 & \pm 94 & \pm 425 & \pm 2774 & \pm 4811 & \pm 5167 & \pm 7541 \\
\hline
\end{tabular}

Resultados semelhantes foram encontrados por Silva et al. (2009) ao incluírem na dieta de cordeiros o simbiótico comercial "BioSyn MOS® ovinos e caprinos", constituído por Saccharomyces cerevisiae $\left(4,1 \times 10^{9} \mathrm{UFC} / \mathrm{g}\right)$, Lactobacillus casei e L. acidophilus 
(2,8×107 UFC/g), mananoligossacarídeo, biotina, histidina, vitaminas A, E, B12 e D3. Os autores reportaram que ao final de 45 dias de confinamento, o grupo simbiótico apresentou a contagem de 863 OPG contra 2863 OPG no grupo controle, destacando que o preparado simbiótico apresentou uma eficácia significativa $(\mathrm{p}<0,05)$ de $70 \%$ na redução de OPG.

Gallina et al. (2009) infectaram experimentalmente ovinos com 5000 larvas de terceiro estádio ( $\mathrm{L}_{3}$ infectante) de H. contortus, 15 dias depois de incluir uma preparação probiótica constituída de Bacillus cereus var. toyoi, S. boulardii e $S$. cerevisae na dieta dos animais. Observaram que após 49 dias de infecção, ocorreu uma redução no número de ovos nas fezes dos animais dos grupos que receberam a referida preparação probiótica, porém, não significativa quando comparado ao grupo controle.

Os resultados apresentados na Tabela 5 demonstram ainda que a partir do $45^{\circ}$ dia de tratamento, os animais do grupo C (Diantel $\left.{ }^{\circledR}\right)$ apresentaram um aumento significativo $(\mathrm{p}<0,05)$ na contagem OPG quando comparado aos grupos A (controle) e B (probiótico). Estes resultados demonstram a baixa eficácia apresentada pelo vermífugo Diantel@ no controle de $H$. contortus.

Em relação ao grupo D no qual os animais receberam uma dose de Diantel® no início do experimento e entre os dias 30 e 60, receberam $10 \mathrm{~mL}$ da preparação probiótica em estudo, foi observada no primeiro mês de experimento, onde os animais estiveram sob o efeito do anti-helmíntico, que a redução do OPG foi significativa $(p<0,05)$ quando comparando ao grupo controle, porém, no segundo mês ocorreu um considerável aumento, alcançando no $60^{\circ}$ dia contagem de OPG de 3375. Verifica-se, desta forma, que a preparação probiótica não exerceu efeito sobre a prevenção da infestação por $H$. contortus, tendo em vista, provavelmente a sensibilidade das cepas de Lactobacillus ao princípio ativo (closantel) do Diantel®. Acrescenta-se ainda que os níveis de OPG observados nos grupos C e D após 60 dias de tratamento sugerem uma nova aplicação de Diantel®, conforme preconizado pelo fabricante.

Neste contexto, vale salientar que em trabalho realizado por Hlasta et al. (1998) no sentido de identificar o farmacóforo (parte da estrutura química de um composto importante para a sua atividade biológica, onde substituições em sua composição podem ser feitas para aumentar a atividade ou eliminar os efeitos secundários indesejados) do closantel na tentativa de formar novos compostos com atividade antimicrobiana contra bactérias Gram-positivas, estes autores verificaram por meio do MIC (Concentração Inibitória Mínima), que $1 \mu \mathrm{g} / \mathrm{mL}$ do closantel foi capaz de inibir o crescimento de cepas de 
Staphylococcus aureus meticilina resistente e Enterococcus faecium vancomicina resistentes.

No que diz respeito à avaliação da eficácia de cada tratamento sobre a infestação por $H$. contortus, verifica-se na Tabela 6 que o valor máximo obtido para a preparação probiótica em estudo foi de $66,3 \%$ após 30 dias de tratamento. No tocante ao Diantel®, observa-se que a eficácia máxima (90,3\%) foi obtida nos animais do grupo D, após 15 dias de experimento, sendo que, após 60 dias, a eficácia de ação foi mínima, o que sugere uma nova aplicação do vermífugo. Vale salientar que a discrepância nos valores obtidos entre os grupos C e D, se deve possivelmente, ao fato que alguns animais desses grupos pudessem estar hospedando parasitos resistentes ao closantel (CHARON, 2004)

Neste sentido, vale ressaltar que de acordo com Sreter; Molnar; Kassai (1994) a tolerância ao parasitismo pode variar entre indivíduos de raças diferentes e mesmo dentro da própria raça, provocando uma desuniformidade na distribuição dos helmintos no rebanho.

Tabela 6 - Valores de eficácia de redução de OPG nas fezes de animais submetidos a diferentes tratamentos

\begin{tabular}{|c|c|c|c|c|c|c|}
\hline \multirow{2}{*}{ Grupos } & \multicolumn{6}{|c|}{ Período de Tratamento (dias) } \\
\hline & 15 & 30 & 45 & 60 & 75 & 90 \\
\hline B & $46,1 \%$ & $66,3 \%$ & $49,3 \%$ & $32,3 \%$ & $30,6 \%$ & $39,3 \%$ \\
\hline $\mathrm{C}$ & $38,5 \%$ & $57,9 \%$ & $0,0 \%$ & $0,0 \%$ & $0,0 \%$ & $0,0 \%$ \\
\hline $\mathrm{D}$ & $90,3 \%$ & $78,6 \%$ & $34,0 \%$ & $0,0 \%$ & $0,0 \%$ & $0,0 \%$ \\
\hline
\end{tabular}

Inúmeros casos de resistência ao closantel tem sido registrados no país. Ramos et al. (2002), avaliando a atuação de anti-helmínticos em 65 rebanhos de ovinos do estado de Santa Catarina, identificaram resistência ao closantel em 13\% dos rebanhos, sendo que $100 \%$ das larvas isoladas eram de Haemonchus.

Avaliando a eficácia de ação de diferentes anti-helminticos sobre parasitos gastrointestinais de ovinos na Região Noroeste do Estado do Paraná, Ramalho et al. (2008) avaliaram 36 ovinos, distribuídos em três lotes, os quais receberam diferentes tratamentos a base de levamisole $(5 \mathrm{mg} / \mathrm{kg})$, closantel $(5 \mathrm{mg} / \mathrm{kg})$ e moxidectina $(0,2 \mathrm{mg} / \mathrm{kg})$. Os autores reportaram resistência dos parasitos a todos os anti-helmínticos avaliados, sendo que a 
resistência por $H$. contortus aos três princípios ativos avaliados foi extremamente alta, tendo apresentado valores de 90,84\% ao levamisole, e $100 \%$ ao closantel e moxidectina.

Resultado semelhante ao obtido no presente trabalho $(57,9 \%)$ foi reportado por Falbo et al. (2009), onde registraram por meio da redução da contagem de OPG, eficácia de ação do closantel de apenas $55,2 \%$ em cordeiros naturalmente infectados com Haemonchus sp.. Empregando a mesma metodologia, Almeida et al. (2010) observaram uma múltipla resistência por $H$. contortus e Trichostrongylus colubriformis em ovinos no estado de São Paulo, sendo que em nenhum dos animais tratados com closantel verificouse uma redução na contagem do OPG. Em levantamento realizado no estado de Mato Grosso do Sul por Sczesny-Moraes et al. (2010), apenas 6,7\% do rebanho apresentaram indivíduos sensíveis ao closantel.

Verifica-se desta forma que há necessidade de aplicação de uma nova dose do Diantel® após 60 dias e seus possíveis efeitos colaterais, como: apatia, depressão, cólica, decúbito lateral, cegueira, distúrbios neurológicos (FURLAN et al., 2009), podem ser observados.

\subsection{AVALIAÇÃO DO TECIDO HEMATOPOÉTICO}

\subsubsection{Leucograma}

Segundo Lee et al. (1998) o leucograma consiste de um exame que permite a identificação e verificação da evolução de diversos processos patológicos, onde se avalia tanto a contagem global (Leucometria), como também a contagem diferencial dos leucócitos.

Observa-se que, no tocante a leucometria (Tabela 7 e Apêndice B), os valores obtidos para os animais que receberam a preparação probiótica em estudo (Grupo B) foram estatisticamente $(\mathrm{p}<0,05)$ inferiores aos obtidos com os animais que não receberam probióticos (Grupos A e C) ao longo do período do experimento. O mesmo foi observado em estudo realizado por Pereira (2007), quando se comparou animais tratados (com preparado probiótico) com animais infectados por Eimeria spp, segundo o autor esta diferença pode estar relacionada com a produção de citocinas, induzida pelos lactobacilos quando presentes na mucosa do intestino, que poderiam estar interagindo com as células da 
corrente sanguínea. Estas estariam promovendo o deslocamento do "pool" central de células leucocitárias para o "pool" marginal, favorecendo desta maneira a diapedese, para em seguida exercer suas funções sobre o parasito (ABBAS; LICHTMAN; PILLAI, 2008).

Nota-se ainda que os resultados obtidos para os diferentes grupos avaliados, exceto grupo A (controle) após 45 dias, encontram-se dentre dos valores de referência reportado na literatura, que variam entre 4000 a $12000 / \mu$ L (AIELLO, 2001).

Tabela 7 - Valores médios \pm desvio padrão da leucometria (Leucócitos/ $\mu \mathrm{L}$ ) dos animais submetidos a diferentes tratamentos

\begin{tabular}{cccccccc}
\hline \multirow{7}{*}{ Grupos } & \multicolumn{7}{c}{ Tempo de Experimento (dias) } \\
\cline { 2 - 8 } & 0 & 15 & 30 & 45 & 60 & 75 & 90 \\
\hline \multirow{2}{*}{$\mathrm{A}$} & 7930 & 9660 & 9040 & $\mathbf{1 2 2 9 0}$ & 10775 & 8388 & 7513 \\
& \pm 2285 & \pm 3341 & \pm 2234 & \pm 3303 & \pm 3287 & \pm 2670 & \pm 2168 \\
& 6122 & 6378 & 7000 & 9067 & 7900 & 6900 & 6000 \\
$\mathrm{~B}$ & \pm 1224 & \pm 933 & \pm 1320 & \pm 1577 & \pm 1284 & \pm 1184 & \pm 904 \\
& 7833 & 7878 & 8433 & 11163 & 10186 & 9800 & 10900 \\
$\mathrm{C}$ & \pm 1955 & \pm 2184 & \pm 2277 & \pm 2024 & \pm 2331 & \pm 3838 & \pm 3258 \\
& 8988 & 8738 & 8500 & 11163 & 10463 & 8463 & 8213 \\
$\mathrm{D}$ & \pm 2420 & \pm 1701 & \pm 1812 & \pm 2932 & \pm 2429 & \pm 2365 & \pm 2178 \\
\hline
\end{tabular}

Zacharias (2004) em estudo sobre efeito de tratamento homeopático sobre a infecção causada por $H$. contortus em ovinos, com duração de 68 dias, também encontrou valores de leucometria normais, com médias de $9160 / \mu \mathrm{L}$ no grupo controle, $9070 / \mu \mathrm{L}$ no grupo tratado com anti-helmíntico e $8625 / \mu \mathrm{L}$ no grupo tratado com o homeopático.

Em relação à contagem diferencial dos leucócitos, verifica-se na Tabela 8 que os valores obtidos para eosinófilos, apresentaram alterações após 45 dias nos animais dos grupos C e D. Tendo em vista que os eosinófílos, através da ação tóxica de seus grânulos citoplasmáticos, estão diretamente envolvidos na resposta imune contra organismos não fagocitáveis, como os helmintos (ABBAS; LICHTMAN; PILLAI, 2008), seu aumento se deve a maior atividade parasitária, observada através da contagem de OPG, que a partir na mesma data também aumentou significativamente.

Nota-se ainda (Tabela 8) que, em decorrência da diminuição do número de linfócitos, observou-se um aumento no número de neutrófilos segmentados nos grupos A, C e D. Quanto aos demais parâmetros avaliados (neutrófilos bastão, basófilos e monócitos), os valores obtidos não diferem estatisticamente entre si nos diferentes grupos estudados. 
Tabela 8 - Valores médios \pm desvio padrão da contagem diferencial de células leucocitárias dos animais submetidos a diferentes tratamentos

\begin{tabular}{|c|c|c|c|c|c|c|c|c|c|c|c|c|}
\hline \multirow[b]{3}{*}{ Grupos } & \multicolumn{12}{|c|}{ Tempo de Experimento (dias) } \\
\hline & \multicolumn{6}{|c|}{ 0 } & \multicolumn{6}{|c|}{15} \\
\hline & $\begin{array}{c}\text { Nbast } \\
(\%)\end{array}$ & $\begin{array}{c}\text { Nseg } \\
(\%)\end{array}$ & $\begin{array}{c}\text { EOS } \\
(\%)\end{array}$ & $\begin{array}{l}\text { BAS } \\
(\%)\end{array}$ & $\begin{array}{l}\text { LIN } \\
(\%)\end{array}$ & $\begin{array}{c}\text { MON } \\
(\%)\end{array}$ & $\begin{array}{c}\text { Nbast } \\
(\%)\end{array}$ & $\begin{array}{c}\text { Nseg } \\
(\%)\end{array}$ & $\begin{array}{c}\text { EOS } \\
(\%)\end{array}$ & $\begin{array}{l}\text { BAS } \\
(\%)\end{array}$ & $\begin{array}{l}\text { LIN } \\
(\%)\end{array}$ & $\begin{array}{c}\text { MON } \\
(\%)\end{array}$ \\
\hline A & $0.3 \pm 0.7$ & $55.4 \pm 8.2$ & $4.0 \pm 3.0$ & $0.1 \pm 0.1$ & $38.7 \pm 10.8$ & $1.5 \pm 2.4$ & $0.2 \pm 0.4$ & $56.1 \pm 11.0$ & $5.7 \pm 4.0$ & $0.0 \pm 0.0$ & $36.6 \pm 11.0$ & $1.4 \pm 0.3$ \\
\hline B & $0.1 \pm 0.3$ & $48.6 \pm 8.5$ & $6.3 \pm 2.1$ & $0.0 \pm 0.0$ & $44.3 \pm 9.0$ & $0.7 \pm 0.7$ & $0.2 \pm 0.4$ & $53.1 \pm 8.5$ & $7.1 \pm 6.6$ & $0.0 \pm 0.0$ & $38.3 \pm 9.8$ & $1.3 \pm 1.7$ \\
\hline $\mathrm{C}$ & $0.6 \pm 1.1$ & $50.4 \pm 10.8$ & $7.3 \pm 4.6$ & $0.1 \pm 0.1$ & $40.6 \pm 10.5$ & $1.0 \pm 1.7$ & $0.2 \pm 0.4$ & $53.0 \pm 13.1$ & $6.7 \pm 4.9$ & $0.0 \pm 0.0$ & $38.7 \pm 9.8$ & $1.4 \pm 3.2$ \\
\hline $\mathrm{D}$ & $0.3 \pm 0.5$ & $45.5 \pm 7.7$ & $7.2 \pm 5.8$ & $0.1 \pm 0.0$ & $46.1 \pm 11.7$ & $0.8 \pm 1.2$ & $0.4 \pm 0.5$ & $47.5 \pm 9.1$ & $7.4 \pm 2.8$ & $0.0 \pm 0.1$ & $44.4 \pm 7.7$ & $0.3 \pm 0.1$ \\
\hline
\end{tabular}

Tabela 8 - (continuação)

\section{Tempo de Experimento (dias)}

\begin{tabular}{|c|c|c|c|c|c|c|c|c|c|c|c|c|}
\hline Grupos & \multicolumn{6}{|c|}{30} & \multicolumn{6}{|c|}{45} \\
\hline A & $0.5 \pm 0.7$ & $54.6 \pm 8.3$ & $5.5 \pm 3.5$ & $0.0 \pm 0.0$ & $38.0 \pm 8.6$ & $1.4 \pm 2.0$ & $0.3 \pm 0.7$ & $54.4 \pm 8.7$ & $7.8 \pm 3.8$ & $0.0 \pm 0.0$ & $36.0 \pm 8.9$ & $1.5 \pm 2.4$ \\
\hline $\mathrm{C}$ & $0.1 \pm 0.3$ & $46.0 \pm 11.2$ & $9.9 \pm 7.2$ & $0.0 \pm 0.0$ & $42.3 \pm 11.5$ & $1.7 \pm 2.9$ & $0.2 \pm 0.3$ & $48.1 \pm 10.4$ & $10.9 \pm 5.5$ & $0.0 \pm 0.1$ & $40.0 \pm 7.4$ & $0.8 \pm 1.3$ \\
\hline $\mathrm{D}$ & $0.3 \pm 0.7$ & $42.8 \pm 7.8$ & $8.0 \pm 3.1$ & $0.0 \pm 0.0$ & $48.7 \pm 7.5$ & $0.2 \pm 0.1$ & $0.6 \pm 0.7$ & $45.5 \pm 7.0$ & $11.1 \pm 5.2$ & $0.1 \pm 0.2$ & $41.0 \pm 8.9$ & $1.7 \pm 2.7$ \\
\hline
\end{tabular}


Tabela 8 - (continuação)

\begin{tabular}{|c|c|c|c|c|c|c|c|c|c|c|c|c|}
\hline \multirow{2}{*}{ Grupos } & \multicolumn{12}{|c|}{ Tempo de Experimento (dias) } \\
\hline & \multicolumn{6}{|c|}{60} & \multicolumn{6}{|c|}{75} \\
\hline B & $0.1 \pm 0.3$ & $45.8 \pm 9.5$ & $8.4 \pm 5.5$ & $0.0 \pm 0.0$ & $45.4 \pm 10.3$ & $0.3 \pm 0.1$ & $0.1 \pm 0.2$ & $45.7 \pm 10.7$ & $9.5 \pm 3.9$ & $0.1 \pm 0.2$ & $42.9 \pm 12.5$ & $1.7 \pm 2.1$ \\
\hline $\mathrm{C}$ & $0.6 \pm 0.8$ & $49.9 \pm 10.2$ & $10.3 \pm 7.8$ & $0.0 \pm 0.0$ & $38.0 \pm 6.8$ & $1.2 \pm 1.7$ & $0.1 \pm 0.1$ & $50.5 \pm 12.9$ & $12.1 \pm 6.2$ & $0.1 \pm 0.1$ & $35.1 \pm 10.7$ & $2.1 \pm 2.8$ \\
\hline $\mathrm{D}$ & $0.4 \pm 0.7$ & $49.0 \pm 13.0$ & $10.7 \pm 7.4$ & $0.1 \pm 0.1$ & $38.5 \pm 7.6$ & $1.3 \pm 1.9$ & $0.1 \pm 0.3$ & $49.2 \pm 9.1$ & $11.6 \pm 6.8$ & $0.1 \pm 0.3$ & $38.3 \pm 6.7$ & $0.7 \pm 0.7$ \\
\hline
\end{tabular}

Tabela 8 - (continuação)

\begin{tabular}{ccccccc}
\hline & \multicolumn{5}{c}{ Tempo de Experimento } \\
\cline { 2 - 7 } Grupos & \multicolumn{5}{c}{$\mathbf{9 0}$} \\
\cline { 2 - 6 } & Nbast (\%) & Nseg (\%) & EOS (\%) & BAS (\%) & LIN (\%) & MON (\%) \\
\hline A & $0.1 \pm 0.4$ & $57.8 \pm 7.2$ & $5.1 \pm 1.7$ & $0.0 \pm 0.0$ & $35.4 \pm 5.2$ & $1.6 \pm 1.4$ \\
B & $0.1 \pm 0.4$ & $49.7 \pm 11.0$ & $6.2 \pm 4.3$ & $0.1 \pm 0.2$ & $41.9 \pm 13.8$ & $2.0 \pm 2.7$ \\
C & $0.3 \pm 0.5$ & $51.9 \pm 12.5$ & $\mathbf{1 0 . 8} \pm 7.2$ & $0.1 \pm 0.2$ & $35.4 \pm 11.5$ & $1.5 \pm 3.4$ \\
D & $0.3 \pm 0.7$ & $53.1 \pm 8.6$ & $\mathbf{1 0 . 9} \pm 1.8$ & $0.1 \pm 0.2$ & $34.7 \pm 9.2$ & $0.9 \pm 1.1$ \\
\hline
\end{tabular}

Valores de Referência (AIELLO, 2001)

\begin{tabular}{cccccc}
\hline $\begin{array}{c}\text { Nbast } \\
(\%)\end{array}$ & $\begin{array}{c}\text { Nseg } \\
(\boldsymbol{\%})\end{array}$ & $\begin{array}{c}\text { EOS } \\
(\boldsymbol{\%})\end{array}$ & $\begin{array}{c}\text { BAS } \\
(\boldsymbol{\%})\end{array}$ & $\begin{array}{c}\text { LIN } \\
(\boldsymbol{\%})\end{array}$ & $\begin{array}{c}\text { MON } \\
(\boldsymbol{\%})\end{array}$ \\
\hline $0-1$ & $10-50$ & $0-10$ & $0-3$ & $40-75$ & $0-6$ \\
\hline
\end{tabular}

Nbast $=$ Neutrófilo bastão, Nseg $=$ Neutrófilo segmentado, EOS $=$ Eosinófilos, BAS = Basófilos, LIN = Linfócitos, MON = Monócitos 
De acordo com Rahman; Collins (1991), os valores normais de leucometria nos casos de infecção por Haemonchus sp. seriam provocados pela linfopenia (redução dos linfócitos) causada pelo parasito, conforme observado no presente trabalho (Figura 4). Nota-se que os animais do grupo A apresentaram uma ligeira linfopenia, inferior a $40.0 \%$ (Aiello, 2001), durante todo experimento e os animais dos grupos C e D apresentaram uma redução após 45 dias, correlacionado com o aumento do número OPG.

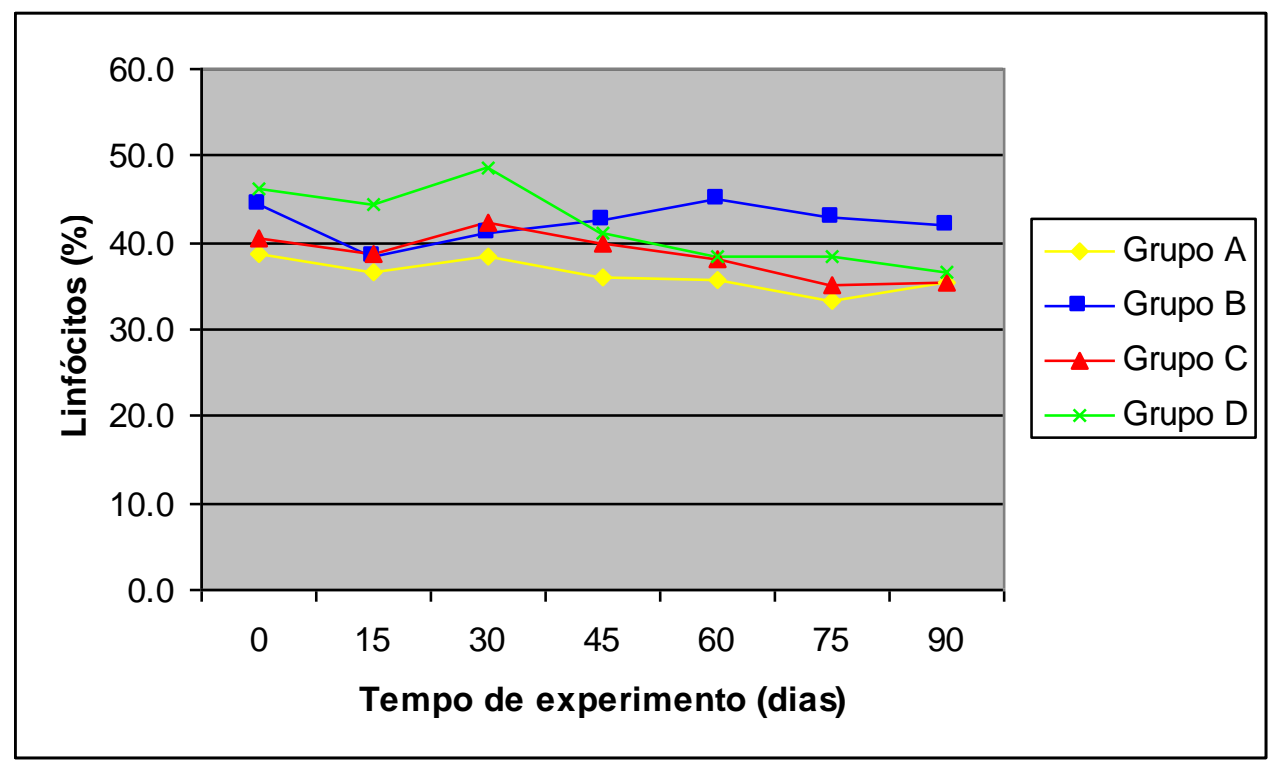

Figura 4 - Contagem relativa dos linfócitos dos animais submetidos a diferentes tratamentos

Avaliando o efeito de verminose na resposta imune de caprinos, Silva et al. (2002), estudaram 90 animais adultos, naturalmente infectados que foram distribuídos em três grupos com base na contagem de OPG nas fezes, sendo Grupo I de 0 a 500, Grupo II de 501 a 2000 e Grupo III > 2000 OPG. Os resultados demonstram que a contagem absoluta de linfócitos dos animais dos Grupos I e II esteve acima de $4100 \mathrm{cel} / \mu \mathrm{L}$ e os animais do Grupo III apresentaram média de $2600 \mathrm{cel} / \mu \mathrm{L}$. Os autores concluíram que existe uma correlação negativa entre a contagem de OPG e o número de linfócitos.

Por outro lado, verifica-se (Figura 4) que número de linfócitos manteve-se normal nos animais do grupo B, diferindo estatisticamente do grupo A (controle), demonstrando que a inclusão da preparação probiótica na dieta dos ovinos apresentou um efeito imunomodulador positivo, estimulando a produção dos linfócitos.

Bactérias dos gêneros Lactobacillus e Bifidobacterium estão diretamente relacionados com o estímulo da resposta imune pelo aumento da produção de anticorpos, 
ativação de macrófagos, proliferação de linfócitos $\mathrm{T}$, produção de citocinas entre outros (BUDIÑO et al., 2004; VARAVALLO; THOMÉ; TESHIMA, 2008).

Shu; Qu; Gill (2001) relataram que leitões tratados com Bifidobacterium lactis HN019 apresentaram diminuição na incidência de diarréia associada com Rotavírus e Escherichia coli, concomitante ao aumento dos títulos de anticorpos e da resposta proliferativa dos linfócitos $\mathrm{T}$.

Benyacoub et al. (2005) atribuiram ao aumento no percentual de linfócitos T-CD4 ${ }^{+}$ e de anticorpos IgA na mucosa intestinal, a redução do número de trofozoítos de Giardia no intestino de camundongos, provocada pela inclusão de probiótico na dieta dos animais.

Segundo Murphy; Travers; Walport (2009), a resposta imunológica contra os helmintos gastrintestinais é dependente dos linfócitos. Os antígenos dos helmintos promovem a polarização e consequente proliferação dos linfócitos T CD4+ para resposta Th2, os quais produzem e secretam as citocinas IL-4, IL-5, IL-10 e IL-13. Essas citocinas em conjunto, suprimem a resposta imune celular e estimulam a produção de anticorpos, especialmente IgE pelos linfócitos $\mathrm{B}$, a proliferação de mastócito e promovem o recrutamento de eosinófilos. Os eosinófilos são atraídos para os sítios de invasão dos helmintos por moléculas quimiotáticas liberadas pelos mastócitos e por meio de seus receptores se ligam as $\operatorname{IgE}$ que revestem a superfície do parasito, esta ligação desencadeia sua degranulação, com liberação de proteína e enzimas tóxicas para os helmintos.

\subsubsection{Eritrograma}

Segundo Radostitis et al. (2002), a principal característica da hemoncose é a anemia, provocada pelo hematofagia do parasito. Assim, anemia é uma doença caracterizada fisiologicamente pela insuficiência de hemoglobina ( $\mathrm{Hb}$ ), podendo ser provocada por produção diminuída, destruição aumentada ou perda excessiva de hemácias, conforme observado na hemoncose (AIELLO, 2001).

Tendo em vista a avaliação do efeito da preparação probiótica sobre o estado anêmico dos animais realizou-se o eritrograma (Apêndices C, D e E), que consiste no exame para determinação da contagem global de hemácias, concentração de hemoglobina, percentual de hematócrito, além dos índices hematimétricos (LEE et al., 1998), cujos resultados da contagem de hemácias encontram-se apresentados na Tabela 9. 
Tabela 9 - Valores médios \pm desvio padrão da contagem de hemácias $\left(\mathrm{n}^{\circ} \times 10^{6} / \mu \mathrm{L}\right)$ dos animais submetidos a diferentes tratamentos

\begin{tabular}{cccccccc}
\hline & \multicolumn{7}{c}{ Tempo de Experimento (dias) } \\
\cline { 2 - 8 } Grupos & 0 & 15 & 30 & 45 & 60 & 75 & 90 \\
\hline \multirow{2}{*}{$\mathrm{A}$} & 9.47 & 9.15 & $\mathbf{8 . 8 3}$ & $\mathbf{7 . 9 1}$ & $\mathbf{8 . 2 6}$ & $\mathbf{8 . 0 1}$ & $\mathbf{8 . 1 9}$ \\
& \pm 0.80 & \pm 1.11 & \pm 1.40 & \pm 1.33 & \pm 0.46 & \pm 0.41 & \pm 0.61 \\
& 9.4 & 9.09 & $\mathbf{8 . 9 2}$ & $\mathbf{8 . 6 3}$ & $\mathbf{8 . 8 3}$ & $\mathbf{8 . 7 6}$ & $\mathbf{8 . 7 3}$ \\
B & \pm 0.61 & \pm 0.73 & \pm 0.62 & \pm 0.67 & \pm 0.44 & \pm 0.48 & \pm 0.64 \\
& 9.04 & 8.81 & 9.24 & $\mathbf{8 . 8 2}$ & $\mathbf{8 . 5 2}$ & $\mathbf{7 . 8 4}$ & $\mathbf{7 . 9 6}$ \\
C & \pm 0.67 & \pm 0.88 & \pm 0.74 & \pm 0.86 & \pm 1.00 & \pm 1.30 & \pm 1.27 \\
& 9.73 & 9.68 & 9.70 & 9.03 & 9.25 & $\mathbf{8 . 4 3}$ & $\mathbf{8 . 6 1}$ \\
D & \pm 0.76 & \pm 0.69 & \pm 0.75 & \pm 0.84 & \pm 0.89 & \pm 0.79 & \pm 1.02 \\
\hline
\end{tabular}

No que se refere ao número total de hemácias, Aiello (2001) reporta como valores normais para ovinos, contagens entre 9 a $15 \times 10^{6} / \mu \mathrm{L}$. Observa-se desta forma, que apenas os animais do Grupo D apresentaram contagem dentro dos limites de referência até o $60^{\circ}$ dia, enquanto que os animais dos grupos A (controle) e B (probiótico), após 30 dias apresentaram redução.

Os valores do número de hemácias situados abaixo dos valores de referência, condizem com o quadro de anemia dos animais resultante da infecção por $H$. contortus, onde um verme adulto pode consumir $0,05 \mathrm{~mL}$ de sangue por dia, provocando uma considerável perda sanguínea no animal hospedeiro (URQUHART et al., 1998).

De acordo com Aiello (2001) os valores fisiológicos normais de concentração de hemoglobina para ovinos, compreende a faixa entre 9 a $15 \mathrm{~g} / \mathrm{dL}$, enquanto o pecentual de hematócrito varia entre 27 a $45 \%$, sendo que valores abaixo podem indicar um certo grau de anemia.

A Figura 5 apresenta a variação da concentração de hemoglobina nos animais dos diferentes grupos durante o experimento. 


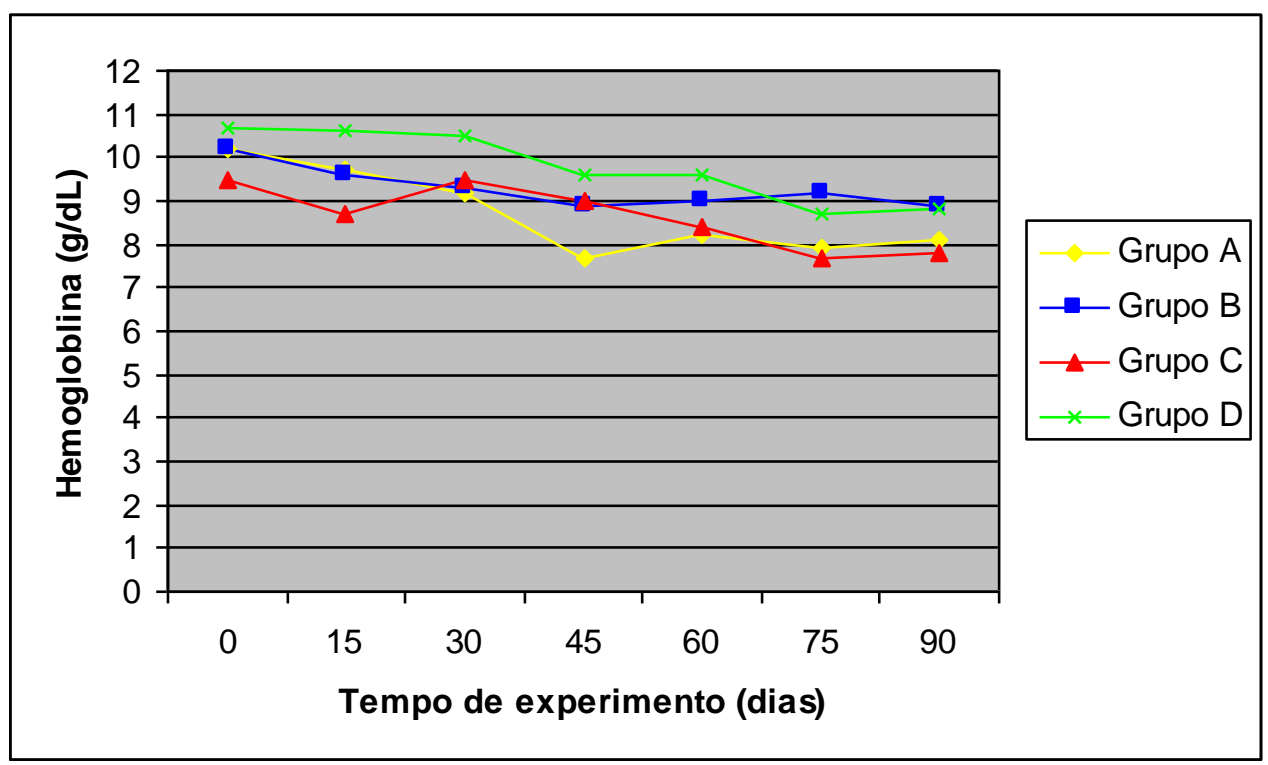

Figura 5 - Concentração de hemoglobina nos animais submetidos a diferentes tratamentos

Nota-se uma redução constante da concentração de hemoglobina nos animais do grupo A (controle), sendo que após 45 dias de experimento estes valores atingiram 7,7 $\mathrm{g} / \mathrm{dL}$. Vale destacar que 2 animais foram eliminados do grupo e tratados com antihelmíntico tendo em vista atingirem a categoria 4 e 5 na escala FAMACHA, correspondendo a 6,2 e 2,7 g/dL de hemoglobina e 17,8 e 8,5\% de hematócrito, respectivamente.

Em relação aos animais do grupo C (Diantel®), observa-se uma intensa queda nos valores destes parâmetros após 45 dias, atingindo concentrações de 7,8 g/dL de hemoglobina e $23,4 \%$ de hematócrito ao final do experimento, sendo observado que dois animais apresentaram intensa anemia e receberam nova dose de vermífugo após 75 dias de experimento.

Quanto aos animais que receberam probióticos (Grupo B), observa-se que apenas nos dias 45 e 90 o valor de hemoglobina ( $8,9 \mathrm{~g} / \mathrm{dL})$ ficou abaixo do valor de referência em ambos os períodos. No que se refere aos animais do grupo $\mathrm{D}$, nota-se que até o $30^{\circ}$ dia do experimento estes valores se mantiveram constantes e a partir do $45^{\circ}$ dia iniciou-se uma queda, persistindo até o final do experimento, onde a concentração de hemoglobina chegou a $8,8 \mathrm{~g} / \mathrm{dL}$.

Observa-se ainda que a queda dos valores de hemoglobina e hematócrito, coincidiu com o aumento do número de OPG, demonstrando, desta forma, a perda do efeito do antihelmíntico sobre o parasito, conforme mostrado na Figura 6. Utilizando a correlação de Pearson verifica-se uma forte correlação negativa entre esses parâmetros nos animais do 
grupo $\mathrm{C}\left(\mathrm{r}=-0,81 ; \mathrm{r}^{2}=0,66\right)$ e do grupo $\mathrm{D}\left(\mathrm{r}=-0,90 ; \mathrm{r}^{2}=0,82\right)$, sendo ambas estatisticamente significativa $(\mathrm{p}<0,05)$. Este efeito também foi observado por Kawano; Yamamura; Ribeiro (2001) e Oliveira (2008), que reportaram reduções nos valores hematológicos dos animais, coincidindo com o aumento no número de OPG, indicando uma maior atividade parasitária por meio da expoliação sanguínea e hemorragia nos pontos de fixação dos vermes na mucosa do abomaso, levando à necessidade de se repetir a vermifugação.

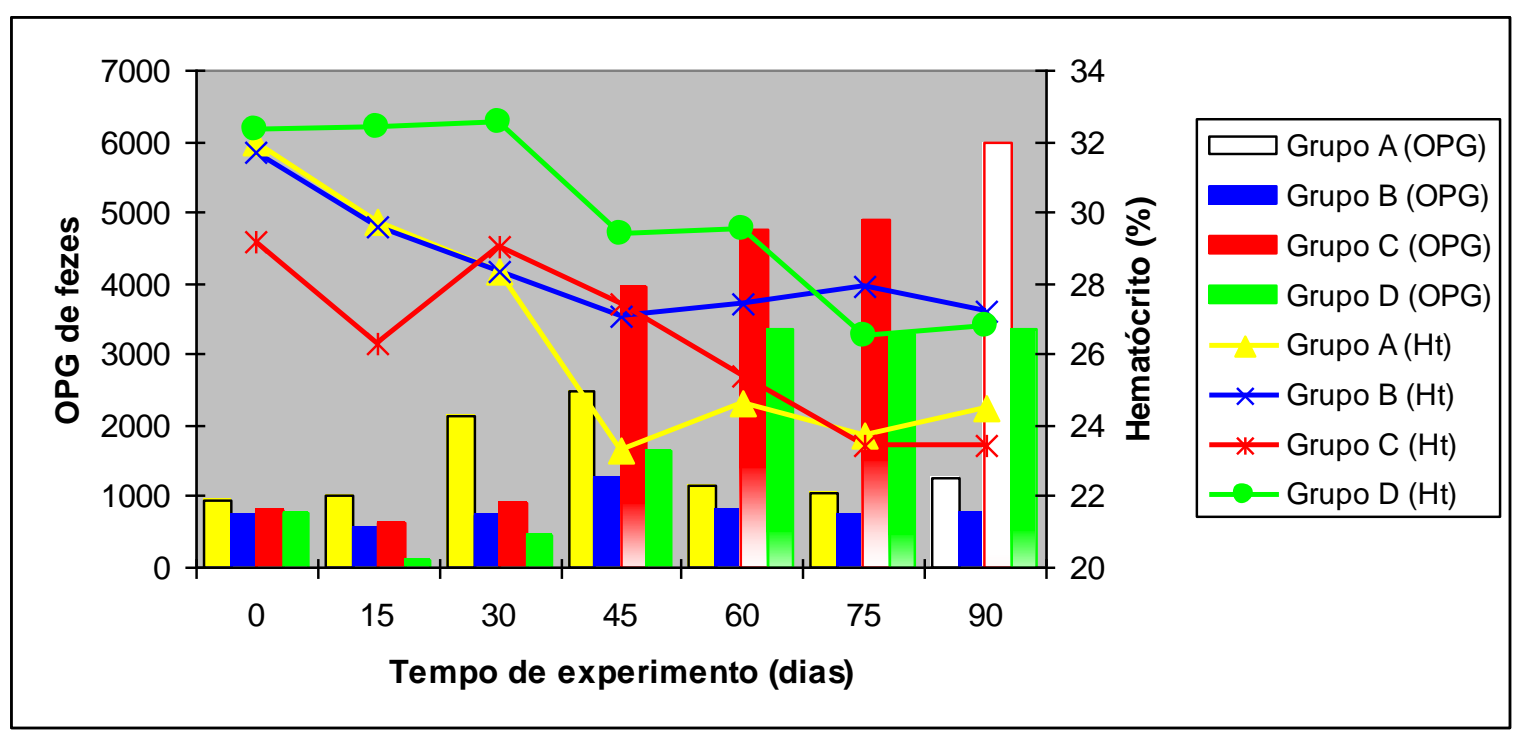

Figura 6 - Valores da OPG e do percentual de hematócrito dos animais submetidos a diferentes tratamentos

Quanto aos animais que receberam probióticos durante todo o experimento (Grupo B), a correlação não foi estatisticamente significativa ( $p>0,05)$, comprovando o fato de que os micro-organismos em estudo promoveram maior tolerância a ação parasitária, mantendo as melhores condições hematológicas. Vale salientar ainda que, durante todo o período do experimento, nenhum animal deste grupo, apresentou-se em condições que levassem a necessidade da interrupção do tratamento e consequente aplicação do anti-helmíntico.

\subsection{NÍVEIS SÉRICOS DE PROTEÍNAS E FERRO}

De acordo com Strain; Stear (2001), a evolução da hemoncose depende da habilidade do animal em compensar as perdas de proteínas e de ferro, utilizado na biosíntese de hemoglobina na tentativa do organismo de se recuperar da anemia provocada 
pela infecção. Desta forma, no presente trabalho as amostras de sangue dos animais submetidos aos diferentes tratamentos foram submetidas a dosagens de proteínas totais e suas frações e ferro, cujos resultados encontram-se representados nas Figuras 7, 8, 9 e 10 (Apêndices F, G, H e I).

Como valores de referência adotou-se aqueles propostos por Aiello (2001) para ovinos que consistem de 5,9 a 7,8 g/dL para proteína, 2,7 a 3,7 g/dL para albumina, 3,2 a $5,0 \mathrm{~g} / \mathrm{dL}$ para globulina, e de $166 \mathrm{a} 222 \mu \mathrm{g} / \mathrm{dL}$ para ferro.

Os resultados representados na Figura 7 demonstram que, apesar dos valores de concentração de proteínas totais permanecerem dentro da faixa de referência, houve uma redução destes valores ao longo do experimento em todos os grupos.

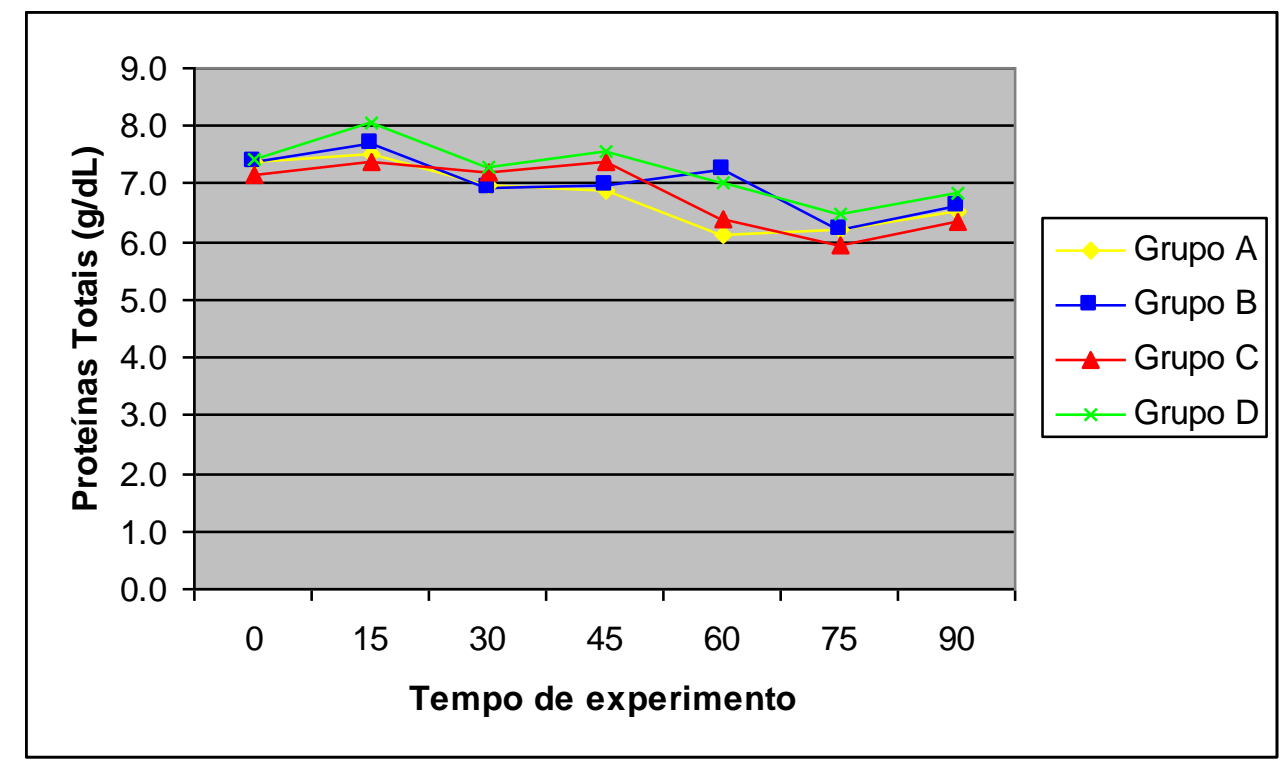

Figura 7 - Concentração de proteínas totais no sangue dos animais submetidos a diferentes tratamentos

No que se refere ao teor de albumina, observa-se (Figura 8) que, ao longo do experimento, os valores obtidos se mantiveram dentro da faixa de referência, com exceção para os animais dos grupos $\mathrm{C}$ e D que foram tratados com Diantel@. Nota-se então, que estes animais apresentaram valores de 2,4 e 2,6 g/dL de albumina após 75 e 90 dias de experimento, respectivamente, indicando o início de uma hipoalbuminemia, provocada pela perda sanguínea em detrimento da parasitose. 


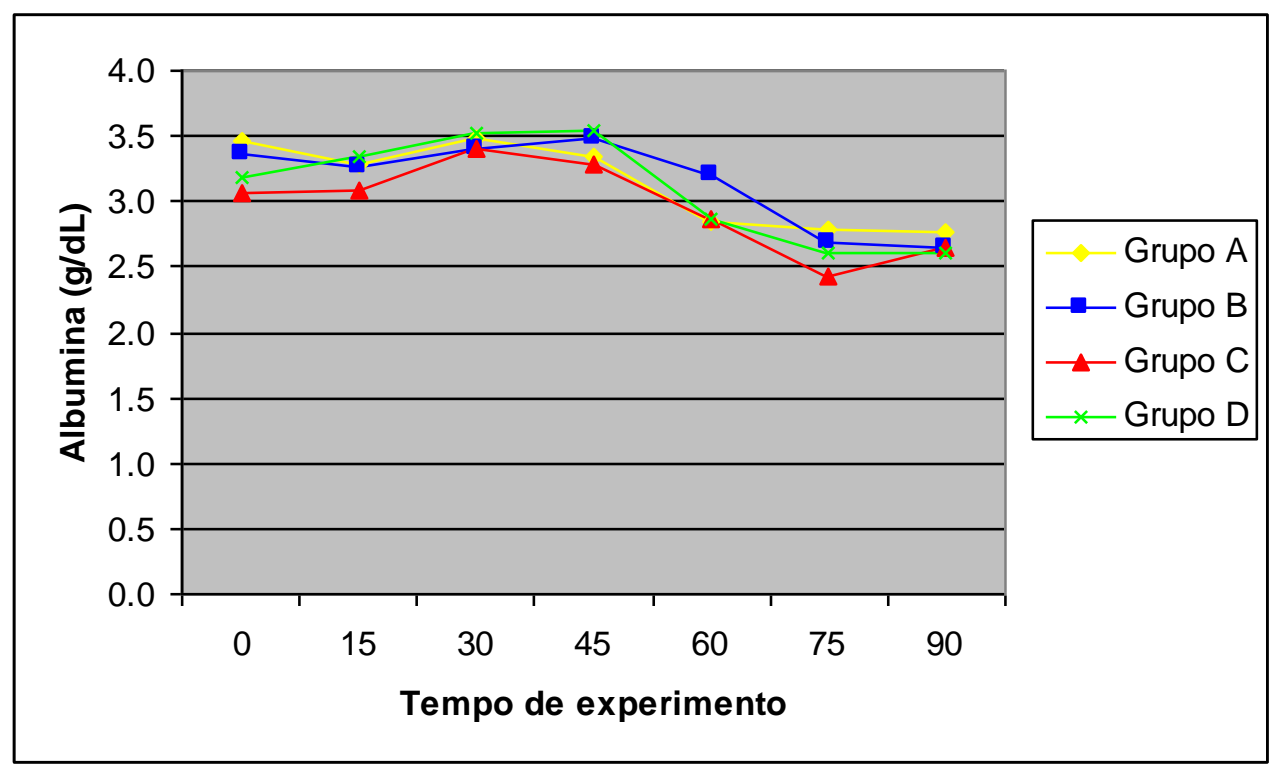

Figura 8 - Concentração de albumina no sangue dos animais submetidos a diferentes tratamentos

Em relação ao teor de globulina (Figura 9), observa-se que os animais dos grupos B e D mantiveram o nível de globulina sem alteração em relação ao inicial, correspondendo a 4,0 e 4,3 g/dL, respectivamente. Por outro lado, verifica-se nos demais grupos, uma queda discreta $(p>0,05)$ na concentração de globulina, assim como observado na concentração de proteínas totais. Nota-se que o menor valor $(3,3 \mathrm{~g} / \mathrm{dL})$ foi observado com os animais do grupo A, após 60 dias de experimento.

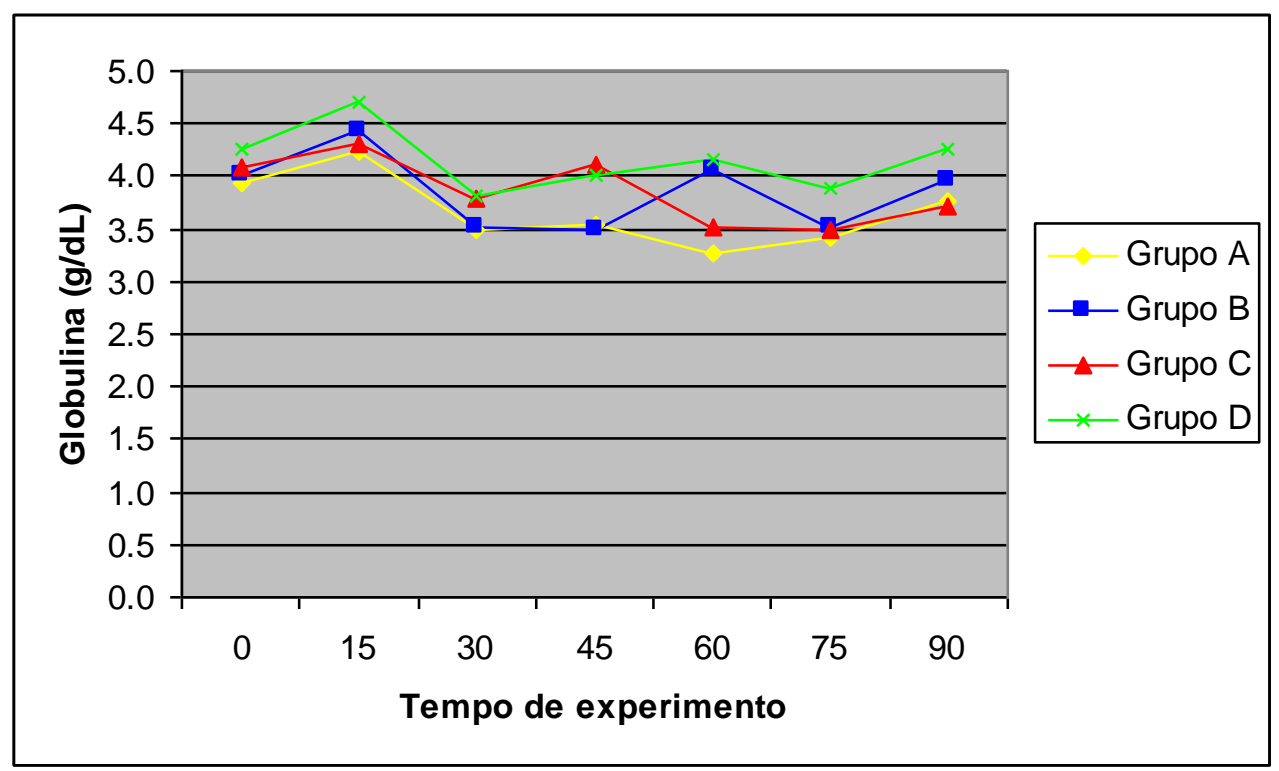

Figura 9 - Concentração de globulina no sangue dos animais submetidos a diferentes tratamentos 
Conforme Silva et al. (2005) a globulina é uma fração protéica, sendo dividida em 05 subfrações: alfa 1, alfa 2, beta 1, beta 2 e gama globulinas. A fração gama é formada pelos vários tipos de imunoglobulinas, entre elas $\operatorname{IgA}, \operatorname{IgD}, \operatorname{IgE}, \operatorname{IgG}$ e $\operatorname{IgM}$, que por sua vez, são sintetizadas pelos linfócitos B.

Desta forma, tendo em vista que a $\operatorname{IgE}$ está diretamente envolvida na resposta imune sobre helmintos, seria importante se determinar a concentração desta imunoglobulina nos animais para obter melhores informações a respeito da imunidade, todavia, não existem kits comerciais para esta avaliação (ROSALINSKI-MORAES et al., 2008).

Estes resultados demonstram um efeito moderado de hipoproteinemia provocada pela hemoncose, resultando em uma redução discreta nos valores de concentração de proteínas totais, albumina e globulina. Acrescenta-se ainda que a preparação probiótica, administrada aos animais dos grupos B e D após 30 dias de experimento, não resultou em resposta positiva no tocante a manutenção do teor de proteínas totais e frações no sangue.

Diversos autores (VELOSO et al., 2004; BRICARELLO et al., 2005; NOGUEIRA; VOLTOLINI; MOREIRA, 2009) tem destacado a importância de uma suplementação protéica na dieta dos animais acometidos por hemoncose. Estes autores ressaltam que este aporte nutricional pode estar associado com a redução do número de OPG e pode resultar no aumento da imunidade, o que contribuiu para melhorar a capacidade dos ovinos de resistir ao efeito dos nematódeos gastrintestinais.

Quanto aos níveis de ferro, observa-se (Figura 10) que os micro-organismos probióticos exerceram efeito positivo sobre a absorção deste elemento. Nota-se então que, devido à hemoncose, nos animais do grupo A (controle) os níveis de ferro se mantiveram significativamente $(\mathrm{p}<0,05)$ inferiores em relação ao grupo $B$, sendo que após 30 dias de experimento os animais desse grupo apresentaram níveis normais de ferro equivalente a $174 \mu \mathrm{g} / \mathrm{dL}$, demonstrando que a preparação probiótica favoreceu a absorção do ferro.

Em relação aos animais dos grupos C e D observa-se que a variação do nível de ferro seguiu o mesmo comportamento verificado com a concentração de hemoglobina e percentual de hematócrito, que consistiu em um aumento gradativo até 45 dias de tratamento seguido de queda constante até o final do experimento. Esta observação revela que a queda dos níveis destes compostos coincide com o aumento do número de OPG, devido à redução do efeito do Diantel® o que sugere uma nova aplicação deste vermífugo, conforme recomendado pelo fabricante. 


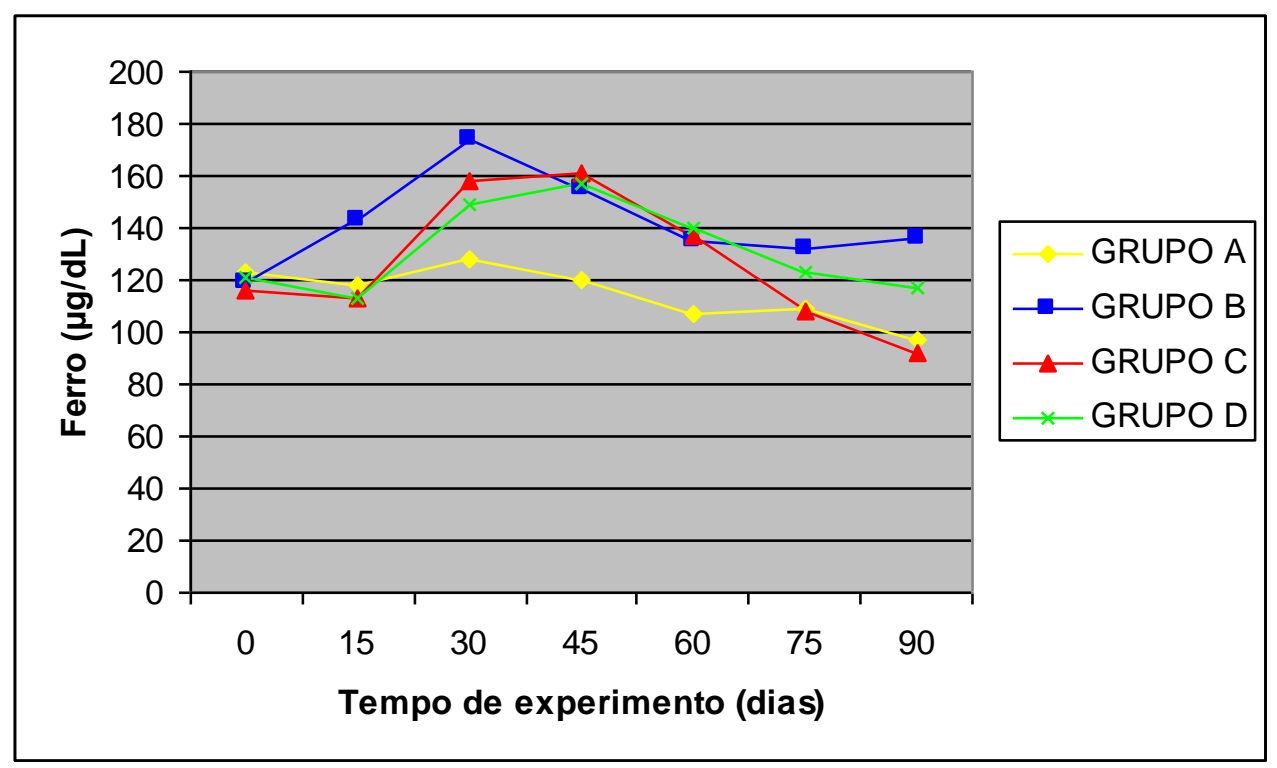

Figura 10 - Concentração de ferro no sangue dos animais submetidos a diferentes tratamentos

O efeito positivo sobre o nível sérico de ferro demonstrado pelas cepas de Lactobacillus que compõem a preparação probiótica em estudo, pode ser explicado pela ação dessas espécies no trato gastrointestinal, influenciando favoravelmente a biodisponibilidade, a digestibilidade e a absorção de alguns nutrientes da dieta dos animais, conforme reportado por Saad (2006). Acrescenta-se ainda que, segundo Huaynate (2008), as respostas mais expressivas resultantes da administração de probióticos são notadas nos animais estressados, como por exemplo aqueles acometidos por verminoses.

Uma outra explicação para o efeito observado se deve ao fato que os ácidos orgânicos produzidos pelas bactérias lácteas levam à diminuição do $\mathrm{pH}$ intestinal, ocasionando a solubilização dos minerais e de seus complexos previamente formados. Estes elementos são melhores absorvidos pelos enterócitos na forma ionizada, atravessando com maior facilidade a membrana celular (YBARRA et al., 2003).

Huyanate et al. (2007), em estudo com suínos alimentados com dietas suplementadas com micro-organismos probióticos verificaram que não houve efeito significativo $(p>0,05)$ no aproveitamento e absorção de ferro e outros minerais Os autores ressaltaram que a ausência de resultados positivos pode estar relacionada ao baixo desafio sanitário ao quais os animais foram submetidos. 


\section{CONCLUSÕES}

Os resultados obtidos no presente trabalho permitem concluir que:

- A preparação probiótica constituída por 4 cepas de Lactobacillus, na forma de "pool", apresentou uma eficácia máxima de $66,3 \%$ na redução do número de OPG, após 30 dias de tratamento.

- O anti-helmíntico avaliado apresentou uma eficácia máxima de 90,3\% na redução do número de OPG, após 15 dias de tratamento, tendo sido evidenciado a necessidade de aplicação de uma nova dose após 60 dias.

- A preparação probiótica quando administrada, nas condições do presente trabalho, apresentou eficácia duradoura quando comparada ao anti-helmíntico avaliado, podendo ser considerada como uma alternativa viável no controle da hemoncose ovina.

- A preparação probiótica quando administrada 3 vezes por semana, 30 dias após o recebimento de uma dose do anti-helmíntico, não contribui positivamente para evitar ou retardar o processo de re-infecção.

- O "pool" de espécies de Lactobacillus estimulou o sistema imune dos animais, mantendo a contagem de linfócitos normais, que por sua vez, estão diretamente envolvidos na resposta imune contra os helmintos.

- Os animais que receberam a preparação probiótica em estudo apresentaram melhores condições fisiológicas no que se refere ao estado anêmico tendo em vista o aumento na concentração de hemoglobina, número de hematócrito e concentração de ferro. 


\section{SUGESTÕES PARA TRABALHOS FUTUROS}

Visando um melhor entendimento sobre a ação de espécies de micro-organismos probióticos sobre a infecção por Haemonchus contortus, os resultados do presente trabalho permitem sugerir a realização de novos experimentos, tais como:

- Estudar a resposta imune compreendendo a: Imunidade humoral, dosando citocinas e anticorpos específicos e a Imunidade celular avaliando-se a população e subpopulação de linfócitos.

- Criar um grupo, onde os animais isentos de verminose, seriam tratados por meio da administração frequente da preparação probiótico e após 30 dias, seriam infectados experimentalmente com larvas $\mathrm{L}_{3}$ de Haemonchus contortus, com a intenção de se avaliar o efeito da referida preparação probiótica na prevenção da infecção.

- Testar novas formas de preparação e administração da preparação probiótica, na intenção de se desenvolver um produto para ser utilizado na rotina das fazendas, facilitando assim, o manejo dos animais. 


\section{REFERÊNCIAS}

ABBAS, A. K.; LICHTMAN, A. H.; PILLAI, S. Imunologia Celular e Molecular. 6. ed. Rio de Janeiro: Elsevier, 2008. 574 p.

ADEMOLA, I. O.; FAGBEMI, B. O.; IDOWU, S. O. Evaluation of the anthelmintic activity of Khaya senegalensis extratct against gastrointestinal nematodes of sheep: in vitro and in vivo studies. Veterinary Parasitology, v. 122, p. 151-164, 2004.

AIELLO, S. E. Manual Merck de Veterinária. 8. ed. São Paulo: Roca, 2001. 1861 p.

ALMEIDA, F. A. et al. Multiple resistance to anthelmintics by Haemonchus contortus and Trichostrongylus colubriformis in sheep in Brazil. Parasitology International, v. 59, p. 622-625, 2010.

AMARANTE, A. F. T. Controle de endoparasitoses dos ovinos. Botucatu, 2004. 6 p. Disponível em: <http://www.fmvz.unesp.br/Informativos/ovinos/repman4.htm>. Acesso em: 20 jun. 2010.

ÁVILA, F. A. et al. Avaliação da eficiência de um probiótico no controle de diarréia e no ganho de peso de bezerros. Arquivo Brasileiro de Medicina Veterinária e Zootecnia, v. 52, n. 1, p. 41-46, 2000.

AXE, D. D.; BAILEY, J. E. Transport of lactate and acetate through the energized cytoplasmic membrane of Escherichia coli. Biotechnology and Bioengineering, v. 47, n. 1, p. 8-19, 1995.

BAIN, B. J. Células sanguíneas. Porto Alegre: Artmed, 1998. 118 p.

BATISTA, C. G. et al. Desempenho e saúde de bezerras alimentadas com leite sem resíduo de drogas antimicrobianas ou leite de vacas tratadas contra mastite adicionado ou não de probiótico. Arquivo Brasileiro de Medicina Veterinária e Zootecnia, v. 60, n. 1, p. 185$191,2008$.

BENYACOUB, J. et al. Enterococcus faecium SF68 enhances the immune response to Giardia intestinalis in mice. The Journal of Nutrtion, v. 153, p. 1171-1176, 2005. 
BERNARDEAU, M.; VERNOUX, J. P.; GUEGUEN, M. Safety and efficacy of probiótico lactobacilli in promoting growth in post-weaning Swiss mice. International Journal of Food Microbiology, v. 77, p. 19- 27, 2002.

BORGES, C. C. L. Atividade in vitro de anti-helmínticos sobre larvas infectantes de nematódeos gastrintestinais de caprinos, utilizando-se a técnica de coprocultura quantitativa (Ueno, 1995). Parasitologia Latinoamericana, v. 58, p. 142-147, 2003.

BORIS, S. et al. Characterization of the aggregation promoting factor from Lactobacillus gasseri, a vaginal isolate. Journal of Applied Microbiology, v. 83, p. 413-420, 1997.

BOWMAN, D. D. Georgi’s Parasitologia Veterinária. 6. ed. Rio de Janeiro: Elsevier, 1995.

BRICARELLO, P. A. Worm burden and immunological responses in Corriedale and Crioula Lanada sheep following natural infection with Haemonchus contortus. Small Ruminant Research, v. 51, p. 75-83, 2004.

BRICARELLO, P. A. et al. Infuence of dietary protein supply on resistance to experimental infections with Haemonchus contortus in Ile de France and Santa Ines lambs. Veterinary Parasitology, v. 134, p. 99-109, 2005.

BRUNO, M. E. C.; MONTVILLE, T. J. Common mechanistic action of bacteriocins from lactic acid bacteria. Applied Environmental Microbiology, v. 59, n. 9, p. 3003-3010, 1994.

BUDIÑO, F. E. L. et al. Influência da adição de probiótico e/ou prebiótico em dietas de leitões desmamados sobre as atividades das enzimas digestivas e parâmetros sanguíneos. Acta Scientiarum Animal Sciences, v. 26, n. 4, p. 529-536, 2004.

CADENAS, E. Biochemistry of oxygen toxicity. Annual Review Biochemistry, v. 58, p. 79-110, 1989.

CADIOLI, F. A. et al. Intoxicação aguda por closantel em cordeiros - relato de caso. Veterinária e Zootecnia, v. 15, n. 2, supl. 1, p. 23, 2008.

CALVETTE, R.; VILLWOCK, L. H. Perfil da ovinocultura de lã e carne do Rio Grande do Sul e seus desafios para o futuro. In: CONGRESSO DA SOBER 45., 2007, Londrina. Anais... Londrina: SOCIEDADE BRASILEIRA DE ECONOMIA, ADMINISTRAÇÃO E SOCIOLOGIA RURAL, 2007. 
CHARON, K.M. Genes controlling resistance to gastrointestinal nematodes in ruminants. Animal Science Papers and Reports, v. 22, p. 135-139, 2004.

CLIMENI, B. S. O.; MONTEIRO, M. V.; CICOTI, C. A. Hemoncose ovina. Revista Científica Eletrônica de Medicina Veterinária, n. 11, 2008.

COPPOLA, M. M.; TURNES, C. G. Efeito de probióticos na resposta imune. Ciência Rural, v. 34, n. 4, p. 1297-1303, 2004.

COELHO, M. D. G. Avaliação do uso de probióticos no controle da infecção causada por Ancylostomidae em cães (Caniis familiaris) naturalmente infectados. 2010. $94 \mathrm{f}$. Tese (Doutorado em Biotecnologia Industrial) - Departamento de Biotecnologia, Escola de Engenharia de Lorena da Universidade de São Paulo, Lorena, SP.

COUTINHO, T. S. Avaliação do efeito de microrganismos probióticos sobre Cryptosporidium parvum em camundongos C57BL/6 imunossupremidos. 2008. $63 \mathrm{f}$. Dissertação (Mestrado em Biotecnologia Industrial) - Departamento de Biotecnologia, Escola de Engenharia de Lorena da Universidade de São Paulo, Lorena, SP.

DALLOUL, R. A. et al. Induction of local protective immunity to Eimeria acervulina by Lactobacillus-based probiotic. Comparative Immunology Microbiology Infectious Diseases, v. 28, p. 351-361, 2005.

DEEGAN, L. H. et al. Bacteriocins: Biological tools for bio-preservation and shelf-life extension. International Dairy Journal, v. 16, n. 8, p.1058-1071, 2006.

DUGGAN, C.; GANNON, J.; WALKER, W. A. Protective nutrients and functional foods for the gastrointestinal tract. American Journal Clinical Nutrition, v. 75, p. 789-808, 2002 .

FALBO, M. K. et al. Atividade anti-helmíntica do triclorfon e closantel em cordeiros naturalmente infectados por Haemonchus sp. Ciência Animal Brasileira, v. 10, n. 3, p. 926-930, 2009.

FAO/WHO - FOOD AND AGRICULTURE ORGANIZATION OF THE UNITED NATIONS, WORLD HEALTH ORGANIZATION. Evaluation of health and nutritional properties of probiotics in food including powder milk with live lactic acid bacteria. Córdoba, 2001. $34 \quad$ p. $\quad 34$ Disponível em: <http://www.who.int/foodsafety/publications/fs_management/en/probiotics.pdf $>$ Acesso em: 20 jun. 2010. 
FERNANDES, L. H. et al. Efeito do pastejo rotacionado e alternado com bovinos adultos no controle da verminose em ovelhas. Arquivos Brasileiro de Medicina Veterinária e Zootecnia, v.56, n.6, p. 733-740, 2004.

FULLER, R. Probiotics in man and animals. Journal of Applied Bacteriology, v. 66, p. 365-378, 1989.

FURLAN, F. H. et al. Intoxicação por closantel em ovinos e caprinos no Estado de Santa Catarina. Pesquisa Veterinária Brasileira, v. 29, p. 89-93, 2009.

GALLINA, T. et al. Utilização de probióticos no controle da infecção de Haemonchus contortus em ovinos. Pelotas, 2009. 4 p. Disponível em: <http://www.ufpel.edu.br/cic/2009/cd/pdf/CA/CA00710.pdf $>$ Acesso em 05 jan. 2010.

GEARY, T. G.; SANGSTER, N. C.; THOMPSON, D. P. Frontiers in anthelmintic pharmacology. Veterinary Parasitology, v. 84, p. 275-295, 1999.

GIROTTO, M. J. et al. O uso de fungos nematófagos no controle biológico de nematóides parasitas: revisão de literatura. Revista Científica Eletrônica de Medicina Veterinária, v. 10, p 21-28, 2008.

GUPTA, V.; GARG, R. Probiotics. Indian Journal of Medical Microbiology, v. 27, n. 3, p. 202-209, 2009.

HENNESSY, D. R.; ALI, D. N. The effect of feed intake level on the pharmacokinetic disposition of closantel in sheep. International Journal of Food Microbiology, v. 27, n. 9, p. 1081-1086, 1997.

HOLZAPFEL, W. H.; SCHILLINGER, U. Introduction to pre- and probiotics. Food Research International, v.35, n.2-3, p.109-116, 2002.

HORDEGEN, P. et al. The anthelmintic efficacy of five plant products against gastrointestinal trichostrongylids in artificially infected lambs. Veterinary Parasitology, v. 117 , p. 51-60, 2003.

HLASTA, D. J. et al. Novel inhibitors of bacterial two-component systems with Grampositive antibacterial activity: pharmacophore identification based on the screening hit closantel. Bioorganic \& Medicinal Chemistry Letters, v. 8, p. 1923-1928, 1998. 
HUMEN, M. A. et al. Lactobacillus johnsonii La1 antagonizes Giardia intestinalis in vivo. Infection and Immunity, v. 73, n. 2, p. 1265-1269, 2005.

HUAYNATE, R. A. R. et al. Métodos de colheita de fezes e balanço de minerais em suínos alimentados com dietas suplementadas ou não com probiótico. Acta Scientiarum Animal Sciences, v. 29, n. 4, p. 395-401, 2007.

HUAYNATE, R. A. R. Probiótico em dietas de suínos. 2008, 66 f. Tese (Doutorado em Zootecnia). Universidade Estadual Paulista - Faculdade de Ciências Agrárias e Veterinárias, Jaboticabal, SP.

IBGE. Instituto Brasileiro de Geografia e Estatística. Produção da pecuária municipal 2009. Rio de Janeiro: IBGE, 2010, v. 37, 55 p.

JACKSON, F.; MILLER, J. Alternative approaches to control - quo vadit. Veterinary Parasitology, v.139, p. 371-384, 2006.

KAWANO, E. L.; YAMAMURA, M. H.; RIBEIRO, E. L. A. Efeitos do tratamento com anti-helmíntico em cordeiros naturalmente infectados com helmintos gastrintestinais sobre os parâmetros hematológicos. Arquivo da Faculdade de Veterinária, v. 29, p. 113-121, 2001.

KÖHLER, P. The biochemical basis of anthelmintic action and resistance. International Journal for Parasitology, v. 31, p. 336-345, 2001.

KWA, M. S.; KOOYMAN, F. N.; BOERSEMA, J. H. Effect of selection for benzimidazole resistance in Haemonchus contortus on B-tubulin isotype 1 and isotype 2 genes. Biochemical Byophysics Research Communication, v. 191, p. 413-419, 1993.

LACERDA, M. J. R. et al. Nota técnica: Vias de aplicação de Closantel como antihelmíntico gastrintestinal em ovinos. Asociación Latinoamericana de Producción Animal, v. 17, n. 1, p. 55-59, 2009.

LAVERMICOCCA, P. et al. Study of adhesion and survival of lactobacilli and bifdobacteria on table olives with the aim of formulating a new probiotic food. Applied and Environmental Microbiology, v. 71, n. 8, p. 4233-4240, 2005.

LEE, G. R. et al. Wintrobe: hematologia clínica. 9. ed. São Paulo: Manole, 1998. vol. 1, $1424 \mathrm{p}$. 
LODDI, M. M. et al. Uso de probiótico e antibiótico sobre o desempenho, o rendimento e a qualidade de carcaça de frangos de corte. Revista Brasileira de Zootecnia, v. 29, n. 4, p. 1124-1131, 2000.

MACHEN, R et al. A Haemonchus contortus management plan for sheep and goats in Texas. Agricultural Communications The Texas A\&M University System, v. 4, p. 98102. 1998.

MACIEL, M. V. et al. Ovicidal and larvicidal activity of Melia azedarach extracts on Haemonchus contortus. Veterinary Parasitology, v. 140, p. 98-104, 2006.

MARTEAU, P.; SALMINEN, S. A inocuidade dos probióticos. Probióticos, outros fatores nutricionais e a microflora intestinal - In: SEMINÁRIO DE NESTLÉ NUTRITION 42., 1998 Anais ..., Suíça. p. 39-40.

MARTIN, F. P. J. et al. Transgenomic metabolic interactions in a mouse disease model: interactions of Trichinella spiralis infection with dietary Lactobacillus paracasei supplementation. Journal of Proteome Research, v. 5, p. 2185-2193, 2006.

MARTIN, R. J. Review: modes of action of anthelmintic drugs. The Veterinary Journal, v. 154, p. 11-34, 1997.

MELO, A. C. F. L. Caracterização do nematóide de ovinos, Haemonchus contortus, resistente e sensível a anti-helmínticos benzimidazóis, no estado do Ceará, Brasil. 2005. 83 f. Tese (Doutorado em Ciências Veterinárias) - Universidade Estadual do Ceará, Fortaleza, CE.

MELO, A. C. F. L.; BEVILAQUA, C. M. L. Abordagem genética da resistência antihelmíntica em Haemonchus contortus. Revista Portuguesa de Ciências Veterinárias. v. 100, p. 141-146, 2005.

MICHIELS, M.; MEULDERMANS, W.; HEYKANTS, J. The metabolism and fate of closantel (flukiver) in sheep and cattle. Drug metabolism reviews, v. 18, p. 235-251, 1987.

MOLENTO, M. B. et al. Método Famacha como parâmetro clínico individual de infecção por Haemonchus contortus em pequenos ruminantes. Ciência Rural, v. 34, p. 1139-1145, 2004. 
MURPHY, K.; TRAVERS, P.; WALPORT, M. Imunobiologia de Janeway. 7. ed. Porto Alegre: Artmed, 2009. 908 p.

NETO, B. B.; SCARMINIO, I. S.; BRUNS, R. E. Como Fazer Experimentos. 4. ed. Porto Alegre: Editora Bookman, 2010. 414 p.

NETO, J. P. N. Panorama da ovinocultura brasileira. 2007. Disponível em: $<$ http://www.rehagro.com.br/siterehagro/publicacao.do?cdnoticia=1471>. Acessado em: 20 jun. 2010.

NEUMANN, M. et al. Utilização de leveduras vivas (Saccharomyces cerevisiae) visando à produção de cordeiros Ile de France super precoces em sistema de creep-feeding. Ciência Rural, v. 38, n. 8, p. 2285-2292, 2008.

NICIURA, S. C. M. et al. Determinação da Eficácia Anti-Helmíntica em Rebanhos Ovinos: Metodologia de Colheita de Amostras e de Informações de Manejo Zoossanitário. São Carlos, 2009. 29 p. Disponível em: $<$ http://www.cppse.embrapa.br/080servicos/070publicacaogratuita/documentos/documento s91.pdf> . Acesso em: 10 jan. 2011.

NOGUEIRA, D. M.; VOLTOLINI, T. V.; MOREIRA, J. N. Efeito da suplementação protéica sobre os parâmetros clínicos e parasitológicos de cordeiros mantidos em pastagem de tifton 85. Ciência Animal Brasileira, v. 10, n. 4, p. 1100-1109, 2009.

OLIVEIRA, D. B. et al. Atividade anti-helmíntica da babaneira (Musa sp.) em caprinos. In: CONGRESSO BRASILEIRO DE PARASITOLOGIA 15., 1997, Salvador. Anais... Salvador: SOCIEDADE BRASILEIRA DE PARASITOLOGIA, 1997. p. 65.

OLIVEIRA, L. L. S. Estudo da infecção por nematóides no período periparto de ovelhas Santa Inês. 2008. 40 f. Dissertação (Mestrado em Zootecnia - Produção de Ruminantes). Universidade Estadual do Sudoeste da Bahia - UESB, Itapetinga, BA.

ONYAH, L. C.; ARSLAN, O. Simulating the development period of a parasite of sheep on pasture under varying temperature conditions. Journal of Thermal Biology, v. 30, p. 203 $211,2005$.

PEÑA M. T. et al. Evaluation of Duddingtonia flagrans in reducing infective larvae of Haemonchus contortus in feces of sheep. Veterinary Parasitology, v. 103, n. 3, p. 259$265,2002$. 
PEREIRA, C. A. S. Propriedades probióticas de Lactobacillus plantarum E Lactobacillus fermentum e antagonismo frente a linhagens de Escherichia coli enteropatogênica (EPEC) e enterotoxigênica (ETEC). 2001. 68 f. Dissertação (Mestrado em Ciências do Alimento - Microbiologia do Alimento). Universidade Federal Rural do Rio de Janeiro - UFRRJ, Seropedica, RJ.

PEREIRA, C. A. S. Avaliação do efeito de microrganismos probióticos sobre Eimeria spp. em Rattus novergicus. 2007. 75 f. Tese (Doutorado em Biotecnologia Industrial) Departamento de Biotecnologia, Escola de Engenharia de Lorena da Universidade de São Paulo, Lorena, SP.

PÉREZ, P. F. et al. Inhibition of Giardia intestinalis by extracellular factors from Lactobacilli: an in vitro study. Applied Environmental Microbiology, v. 67, n. 11, p. 5037-5042, 2001.

PINHEIRO, R. S. B.; SOBRINHO, A. G. S.; YAMAMOTO, S. M. Desempenho de cordeiros lactentes recebendo probióticos em comedouros privativos. Archives of Veterinary Science, v. 11, n. 3, p. 38-42, 2007.

PRICHARD, R. K. Genetic variability following selection of Haemonchus contortus with anthelmintics. Trends in Parasitology. v. 17, p. 445-452, 2001.

RADOSTITIS, O. M. et al. Clínica Veterinária: Um Tratado de Doenças dos Bovinos, Ovinos, Suínos, Caprinos e Eqüinos. 9 ed. Rio de Janeiro: Guanabara Koogan, 2002. 1737 p.

RAHMAN, W. A.; COLLINS, G. H. Changes in live weight gain and blood constituents in experimental infection of goats with a goat-derived compared with a sheep-derived strain of Haemonchus contortus. Veterinary Parasitology, v. 38, p. 145-153, 1991.

RAMALHO, L. et al. Resistência do Haemonchus contortus e outros parasitas gastrintestinais ao levamisol, closantel e moxidectina em um rebanho no noroeste do Paraná. In: OSTRA INTERNA DE TRABALHOS DE INICIAÇÃO CIENTÍFICA DO CESUMAR 4., 2008, Maringá. Anais... Maringá: CESUMAR - CENTRO UNIVERSITÁRIO DE MARINGÁ, 2008.

RAMOS, C. I. et al. Resistência de parasitos gastrintestinais de ovinos a alguns antihelmínticos no estado de Santa Catarina, Brasil. Ciência Rural, v. 32, n. 3, p. 473-477, 2002. 
RANDAZZO, V.; COSTAMAGNA, S. R. Effect of oral administration of probiotic agents Trichinella spiralis-infected mice. Revista de Patologia Tropical, v. 34, n. 2, p. 55-59, 2005.

RISSI, D. R. et al. Doenças de ovinos da região Central do Rio Grande do Sul: 361 casos. Pesquisa Veterinária Brasileira, v. 30, n. 1, p. 21-28, 2010.

ROCHA, R. A. et al. Sheep and cattle grazing alternately: Nematode parasitism and pasture decontamination. Small Ruminants Research, v. 75, p. 135-143, 2008.

ROSA, J. S. Enfermidades em Caprinos: diagnóstico, patogenia, terapêutica e controle Embrapa Caprinos- Brasília - SPI/ Sobral: Embrapa - CNPC. p. 101-105, 1996.

ROSALINSKI-MORAES, F. et al. Produção de antígeno somático de Haemonchus contortus adultos e seu uso em ensaio imunoenzimático indireto para detecção de imunoglobulina G ovina. Archives of Veterinary Science, v. 13, n. 2, p. 118-125, 2008.

ROSS, G. R. et al. Effects of probiotic administration in swine. Journal of Bioscience and Bioengineering, v. 109, n. 6, p. 545-549, 2010.

ROTHWELL, J.; SANGSTER, N. C. Haemonchus contortus: The uptake and metabolism of closantel. International Journal for Parasitology, v. 27, n. 3, p. 313-319, 1997.

SAAD, S. M. I. Probióticos e prébioticos: o estado da arte. Revista Brasileira de Ciências Farmacêuticas, v. 42, n. 1, p. 1-16, 2006.

SANDERS, M. E. Probiotics: considerations for human health. Nutrition, v. 61, n. 3, p. 91-99, 2003.

SANGSTER, N. C. Pharmacology of anthelmintic resistance in cyathostomes: will it occur with the avermectin/milbemycin. Veterinary Parasitology, v. 85, p. 189-204, 1999.

SANTOS, J. F. et al. O efeito da cultura de Zymomonas mobilis na infecção experimental por Schistosoma mansoni. Revista da Sociedade Brasileira de Medicina Tropical, v. 37, n. 6, p. 502-504, 2004.

SCZESNY-MORAES, E. A. et al. Resistência anti-helmíntica de nematóides gastrintestinais em ovinos, Mato Grosso do Sul. Pesquisa Veterinária Brasileira, v. 30, n. 3, p. 229-236, 2010. 
SHU, Q.; QU, F.; GILL, H. S. Probiotic treatement using Bifidobacterium lactis HN019 reduces weanling diarrhea associated with rotavirus and Escherichia coli infection in a piglet model. Journal Pediatric Gastroenterological Nutrition, v. 33, n. 2, p. 171-177, 2001.

SILVA, D. G. K. C. et al. Perfil eletroforético de proteínas plasmáticas: estudo em crianças atendidas no Hospital de Pediatria - Hosped / UFRN da cidade de Natal-RN. Revista Brasileira de Análises Clínicas, v. 37, n. 4, p. 239-242, 2005.

SILVA, M. M. et al. Efeito da verminose na resposta imune em caprinos. Semina: Ciências Agrárias, v. 23, n. 1, p. 15-19, 2002.

SILVA, K. C. F. et al. Efeito de um simbiótico sobre o ganho de peso e número de ovos por grama de fezes de cordeiros confinados. Semina: Ciências Agrárias, v. 30, n. 4, p. 953-962, 2009.

SINGER, S. M.; NASH, T. E. The role of normal flora in Giardia lamblia infections in mice. Journal Infectious Diseases, v. 181, p. 1510-1512, 2000.

SPINOSA, H. S.; GÓRNIAK, S. L.; BERNARDI, M. M. Farmacologia aplicada a medicina veterinária. 4. ed. Rio de Janeiro: Guanabara Koogan, 2006. 897 p.

SRETER, T.; MOLNAR, V.; KASSAI, T. The distribution of nematode egg counts and larval counts in grazing sheep and their implications for parasite control. International Journal for Parasitology, v. 24, p. 103-108, 1994.

STRAIN, S. A. J.; STEAR, M. J. The influence of protein supplementation on the immune response to Haemonchus contortus. Parasite Immunology, v. 23, p. 527-531, 2001.

STROMPFOVÁ, V. et al. Application of potential probiotic Lactobacillus fermentum AD1 strain in healthy dogs. Anaerobe, v. 12, p. 75-79, 2006.

SWAN, G. E. The pharmacology of halogenated salicylanilides and their anthelmintic use in animals. Journal of the South Africa Veterinary Association, v. 70, n. 2, p. 61-70, 1999.

TIERNEY, J. et al. In vitro inhibition of Eimeria tenella invasion by indigenous chicken Lactobacillus species. Veterinary Parasitology, v. 122, p. 171-182, 2004. 
URQUHART, G. M. et al. Parasitologia veterinária. 2.ed. Rio de Janeiro: Guanabara Koogan, 1998, 273 p.

UTIYAMA, C. E. et al. Efeitos de antimicrobianos, prebióticos, probióticos e extratos vegetais sobre a microbiota intestinal, a freqüência de diarréia e o desempenho de leitões recém-desmamados. Revista Brasileira de Zootecnia, v. 35, n. 6, p. 2359-2367, 2006.

Van WYK, J. A.; BATH, G. F. The FAMACHA system for managing haemonchosis in sheep and goats by clinically identifying individual animals for treatment. Veterinary Research, v. 33, p. 509-529, 2002.

VARAVALLO, M. A.; THOMÉ, L. N.; TESHIMA, E. Aplicação de bactérias probióticas para proflaxia e tratamento de doenças gastrointestinais. Semina: Ciências Biológicas e da Saúde, v. 29, n. 1, p. 83-104, 2008.

VELOSO, C. F. M. et al. Efeitos da suplementação protéica no controle da verminose e nas características de carcaça de ovinos Santa Inês. Ciência Animal Brasileira, v. 5, n. 3, p. 131-139, 2004.

VERÍSSIMO, C. J.; CATELLI, L.; MOLENTO, M. B. Integração de ovinos e bovinos: método Famacha, pastejo contínuo e baixa densidade animal no controle parasitário. Revista Brasileira de Parasitologia Veterinária, v. 13, (supl. 1), p. 292, 2004.

VIEIRA, L. S. Métodos alternativos de controle de nematóides gastrointestinais em ovinos. Tecnologia \& Ciência Agropecuária, v. 2, n. 2, p. 49-56, 2008.

WOLSTENHOLME, A. J. et al. Drug resistance in veterinary helminths. Trends in Parasitology, v. 20, p. 469-476, 2004.

YBARRA, L. M. et al. Influência de probióticos e prebióticos na absorção de minerais. 2003. In: FERREIRA, C. L. L. F. Prebióticos e probióticos: atualização e prospecção. Suprema, 79-102 $\mathrm{p}$.

ZACHARIAS, F. Controle alternativo da infecção por Haemonchus contortus em ovinos: avaliação do tratamento homeopático. 2004. 130 f. Dissertação (Mestrado em Medicina Veterinária Tropical) - Escola de Medicina Veterinária da Universidade Federal da Bahia, Salvador, BA. 
APÊNDICES 
APÊNDICE A - Contagem de OPG nas fezes dos animais submetidos a diferentes tratamentos

\begin{tabular}{|c|c|c|c|c|c|c|c|}
\hline \multirow{2}{*}{ Animais } & \multicolumn{7}{|c|}{ Tempo de experimento (dias) } \\
\hline & 0 & 15 & 30 & 45 & 60 & 75 & 90 \\
\hline \multicolumn{8}{|l|}{ Grupo A } \\
\hline 1 & 2300 & 1300 & 10000 & 1300 & - & - & - \\
\hline 2 & 2000 & 1800 & 400 & 1200 & 1200 & 1000 & 1200 \\
\hline 3 & 1900 & 2100 & 1000 & 0 & 4300 & 2200 & 4400 \\
\hline 4 & 800 & 300 & 1600 & 300 & 800 & 2000 & 1000 \\
\hline 5 & 800 & 1000 & 900 & 600 & 1200 & 1100 & 155 \\
\hline 6 & 400 & 0 & 300 & 1200 & 1200 & 600 & 2300 \\
\hline 7 & 400 & 3700 & 7100 & 18100 & - & - & - \\
\hline 8 & 300 & 0 & 100 & 0 & 0 & 900 & 200 \\
\hline 9 & 300 & 100 & 0 & 2100 & 600 & 300 & 100 \\
\hline 10 & 100 & 0 & 0 & 100 & 0 & 400 & 700 \\
\hline \multicolumn{8}{|l|}{ Grupo B } \\
\hline 11 & 2400 & 1700 & 2000 & 1760 & 1300 & 400 & 1600 \\
\hline 12 & 1400 & 700 & 500 & 1700 & 1800 & 1300 & 500 \\
\hline 13 & 800 & 400 & 1000 & 700 & 1500 & 1900 & 870 \\
\hline 14 & 740 & 560 & 720 & 765 & 690 & 640 & 660 \\
\hline 15 & 700 & 400 & 500 & 600 & 0 & 500 & 100 \\
\hline 16 & 400 & 600 & 700 & 4900 & 500 & 400 & 500 \\
\hline 17 & 400 & 500 & 900 & 0 & 890 & 500 & 1800 \\
\hline 18 & 300 & 0 & 300 & 0 & 100 & 840 & 800 \\
\hline 19 & 200 & 500 & 600 & 400 & 500 & 500 & 100 \\
\hline 20 & 100 & 200 & 0 & 1800 & 600 & 400 & 700 \\
\hline \multicolumn{8}{|l|}{ Grupo C } \\
\hline 21 & 2900 & 1200 & 600 & 6900 & 4300 & 2100 & 2200 \\
\hline 22 & 1400 & 500 & 100 & 13500 & 13100 & 9300 & 10000 \\
\hline 23 & 900 & 0 & 1000 & 2300 & 2500 & 3000 & 2000 \\
\hline 24 & 820 & 630 & 600 & 2900 & 4700 & . & - \\
\hline 25 & 700 & 2200 & 2400 & 6500 & 13800 & 15400 & 27100 \\
\hline 26 & 400 & 0 & 700 & 710 & 900 & 790 & 500 \\
\hline 27 & 400 & 900 & 1500 & 2500 & 2700 & 4000 & 6000 \\
\hline 28 & 300 & 0 & 1000 & 2200 & 3000 & 3500 & 100 \\
\hline 29 & 200 & 0 & 0 & 200 & 400 & 1000 & 100 \\
\hline 30 & 200 & 900 & 1100 & 2000 & 2100 & - & - \\
\hline \multicolumn{8}{|l|}{ Grupo D } \\
\hline 31 & 2900 & 200 & 1200 & 9100 & 12400 & 15000 & 24500 \\
\hline 32 & 1300 & 0 & 470 & 1400 & 1500 & 200 & 1200 \\
\hline 33 & 950 & 100 & 500 & 600 & 1450 & 2500 & 3500 \\
\hline 34 & 600 & 100 & 400 & 500 & 2500 & 4080 & 3250 \\
\hline 35 & 500 & 0 & 0 & 0 & 200 & 0 & 100 \\
\hline 36 & 500 & 100 & 900 & 3000 & 12400 & 10000 & 0 \\
\hline 37 & 300 & 100 & 900 & 1330 & 1800 & 600 & 1100 \\
\hline 38 & 300 & 300 & 0 & 100 & 300 & 0 & 0 \\
\hline 39 & 200 & 100 & 100 & 200 & 500 & 200 & 0 \\
\hline 40 & 200 & 0 & 100 & 200 & 700 & 300 & 100 \\
\hline
\end{tabular}


APÊNDICE B - Leucometria (Leucócitos/ $\mu \mathrm{L}$ ) dos animais submetidos a diferentes tratamentos

\begin{tabular}{cccccccc}
\hline \multirow{2}{*}{ Animais } & \multicolumn{7}{c}{ Tempo de experimento (dias) } \\
\cline { 2 - 8 } Grupo A & 0 & 15 & 30 & 45 & 60 & 75 & 90 \\
1 & 7800 & 13300 & 9900 & 13900 & - & - & - \\
2 & 11500 & 10700 & 12400 & 20100 & 15400 & 13500 & 11100 \\
3 & 7700 & 9300 & 5900 & 10900 & 8100 & 8500 & 5500 \\
4 & 10400 & 8100 & 9800 & 11300 & 11100 & 8000 & 9500 \\
5 & 8300 & 6900 & 8400 & 8100 & 9000 & 6700 & 6600 \\
6 & 3900 & 16000 & 10700 & 12500 & 15900 & 10300 & 7800 \\
7 & 5800 & 11800 & 11100 & 12900 & - & - & - \\
8 & 9300 & 6900 & 9100 & 12100 & 10400 & 8400 & 7900 \\
9 & 5800 & 4900 & 5400 & 8600 & 9500 & 7300 & 7500 \\
10 & 8800 & 8700 & 7700 & 12500 & 6800 & 4400 & 4200 \\
\hline Grupo B & & & & & & & \\
11 & 6122 & 6378 & 6000 & 9067 & 7900 & 5900 & 6000 \\
12 & 7300 & 7400 & 9100 & 9700 & 8800 & 6300 & 5900 \\
13 & 4300 & 5300 & 6200 & 5800 & 6200 & 5600 & 4000 \\
14 & 5900 & 4900 & 5400 & 8000 & 6700 & 5600 & 5700 \\
15 & 5900 & 6800 & 7200 & 8700 & 10100 & 8200 & 7300 \\
16 & 4500 & 5200 & 6900 & 10100 & 8300 & 7700 & 5300 \\
17 & 7900 & 7200 & 8600 & 9900 & 6100 & 7200 & 6300 \\
18 & 7700 & 7200 & 8500 & 11900 & 9000 & 7900 & 6300 \\
19 & 6100 & 7100 & 5600 & 8600 & 7600 & 8600 & 6900 \\
20 & 5500 & 6300 & 6500 & 8900 & 8300 & 6000 & 6300 \\
\hline Grupo C & & & & & & & \\
21 & 7833 & 7878 & 8433 & 12163 & 11186 & - & - \\
22 & 8600 & 9400 & 9400 & 12500 & 10000 & 8200 & 10800 \\
23 & 6100 & 6500 & 9600 & 10300 & 7000 & 7600 & 8700 \\
24 & 6500 & 7700 & 8600 & 9100 & 8200 & 7900 & 8000 \\
25 & 11400 & 11000 & 10900 & 12700 & 14000 & 16800 & 17100 \\
26 & 10400 & 11300 & 11100 & 13400 & 10800 & 12100 & 13800 \\
27 & 6100 & 4400 & 4000 & 8800 & 10186 & 7600 & 8900 \\
28 & 9000 & 7500 & 9600 & 14000 & 13600 & 13100 & 12000 \\
29 & 6300 & 7400 & 7200 & 8500 & 7700 & 5100 & 7900 \\
30 & 6100 & 5700 & 5500 & 10163 & 9186 & - & - \\
\hline Grupo D & & & & & & & \\
31 & 7988 & 7738 & 7500 & 10163 & 9463 & 7463 & 7213 \\
32 & 9988 & 9738 & 9500 & 12163 & 11463 & 9463 & 9213 \\
33 & 8300 & 7100 & 5500 & 6500 & 7200 & 4900 & 6000 \\
34 & 6300 & 7100 & 7900 & 9400 & 9300 & 6700 & 6700 \\
35 & 5700 & 9400 & 8800 & 15900 & 10300 & 8800 & 7200 \\
36 & 11200 & 9600 & 8100 & 8500 & 12000 & 8700 & 8800 \\
37 & 13500 & 12200 & 12700 & 14000 & 11700 & 11100 & 10200 \\
38 & 10700 & 6600 & 8200 & 10000 & 9200 & 7800 & 7400 \\
39 & 7000 & 8300 & 8100 & 10500 & 8200 & 6600 & 6300 \\
40 & 9200 & 9600 & 8700 & 14500 & 15800 & 13100 & 13100 \\
\hline & & & & & & & \\
\hline
\end{tabular}


APÊNDICE C - Contagem de hemácias $\left(n^{\circ} \times 10^{6} / \mu \mathrm{L}\right)$ dos animais submetidos a diferentes tratamentos

\begin{tabular}{|c|c|c|c|c|c|c|c|}
\hline \multirow{2}{*}{ Animais } & \multicolumn{7}{|c|}{ Tempo de experimento (dias) } \\
\hline & 0 & 15 & 30 & 45 & 60 & 75 & 90 \\
\hline \multicolumn{8}{|c|}{ Grupo A } \\
\hline 1 & 9.20 & 8.63 & 8.23 & 7.34 & - & - & - \\
\hline 2 & 8.51 & 8.18 & 7.57 & 6.96 & 7.29 & 7.51 & 7.37 \\
\hline 3 & 10.12 & 9.68 & 9.48 & 8.78 & 8.62 & 8.30 & 9.06 \\
\hline 4 & 9.30 & 9.26 & 8.81 & 7.74 & 7.98 & 7.47 & 7.28 \\
\hline 5 & 10.10 & 9.82 & 10.00 & 9.11 & 8.45 & 8.46 & 8.58 \\
\hline 6 & 10.33 & 10.00 & 9.51 & 8.52 & 8.27 & 7.99 & 8.20 \\
\hline 7 & 7.80 & 6.50 & 5.54 & 4.73 & - & - & - \\
\hline 8 & 9.96 & 9.89 & 10.03 & 9.12 & 8.74 & 8.57 & 8.66 \\
\hline 9 & 9.67 & 10.05 & 9.62 & 8.46 & 8.45 & 7.80 & 8.19 \\
\hline 10 & 9.67 & 9.49 & 9.51 & 8.34 & 8.27 & 8.00 & 8.15 \\
\hline \multicolumn{8}{|l|}{ Grupo B } \\
\hline 11 & 9.40 & 9.09 & 8.92 & 8.63 & 8.83 & 8.76 & 8.73 \\
\hline 12 & 8.92 & 8.45 & 9.15 & 8.65 & 8.81 & 8.70 & 8.87 \\
\hline 13 & 8.79 & 8.35 & 8.61 & 8.12 & 8.57 & 8.21 & 8.09 \\
\hline 14 & 8.18 & 7.73 & 7.38 & 7.09 & 7.90 & 7.99 & 7.80 \\
\hline 15 & 10.02 & 9.78 & 9.09 & 9.60 & 9.65 & 9.74 & 9.78 \\
\hline 16 & 9.63 & 9.44 & 8.99 & 8.65 & 9.14 & 8.53 & 8.78 \\
\hline 17 & 9.54 & 9.88 & 9.76 & 8.70 & 8.87 & 8.87 & 8.92 \\
\hline 18 & 9.94 & 9.95 & 9.38 & 8.67 & 8.67 & 8.76 & 7.86 \\
\hline 19 & 10.11 & 9.01 & 8.90 & 9.14 & 8.92 & 9.01 & 9.24 \\
\hline 20 & 9.51 & 9.26 & 8.99 & 9.05 & 8.91 & 9.02 & 9.25 \\
\hline \multicolumn{8}{|l|}{ Grupo C } \\
\hline 21 & 9.04 & 8.81 & 9.28 & 8.84 & 8.56 & - & - \\
\hline 22 & 9.97 & 10.08 & 10.33 & 9.48 & 8.71 & 8.03 & 8.00 \\
\hline 23 & 8.33 & 7.86 & 7.78 & 6.99 & 6.87 & 6.23 & 7.00 \\
\hline 24 & 9.84 & 9.89 & 9.76 & 9.18 & 8.78 & 8.41 & 8.43 \\
\hline 25 & 8.58 & 7.78 & 8.32 & 7.99 & 7.39 & 5.52 & 5.27 \\
\hline 26 & 9.55 & 9.16 & 9.38 & 8.85 & 8.43 & 8.60 & 8.49 \\
\hline 27 & 9.31 & 9.26 & 9.10 & 9.17 & 8.54 & 8.95 & 9.01 \\
\hline 28 & 7.98 & 8.79 & 9.88 & 10.22 & 10.72 & 9.15 & 9.18 \\
\hline 29 & 9.27 & 9.01 & 9.36 & 8.68 & 8.74 & 7.82 & 8.30 \\
\hline 30 & 8.50 & 7.44 & 9.20 & 8.80 & 8.50 & - & - \\
\hline \multicolumn{8}{|l|}{ Grupo D } \\
\hline 31 & 8.73 & 8.68 & 8.70 & 8.03 & 8.25 & 7.43 & 7.61 \\
\hline 32 & 10.73 & 10.68 & 10.70 & 10.03 & 10.25 & 9.43 & 9.61 \\
\hline 33 & 8.50 & 8.79 & 8.58 & 7.68 & 7.69 & 7.07 & 6.66 \\
\hline 34 & 10.08 & 9.86 & 10.06 & 8.98 & 9.49 & 8.89 & 8.46 \\
\hline 35 & 9.74 & 9.16 & 9.14 & 8.39 & 8.31 & 7.82 & 7.67 \\
\hline 36 & 10.25 & 10.39 & 10.01 & 9.80 & 10.02 & 9.13 & 9.83 \\
\hline 37 & 9.01 & 9.18 & 9.81 & 8.70 & 9.06 & 8.05 & 8.98 \\
\hline 38 & 10.36 & 10.00 & 9.74 & 10.01 & 10.18 & 9.06 & 9.57 \\
\hline 39 & 9.60 & 9.81 & 9.51 & 8.93 & 9.54 & 8.79 & 8.69 \\
\hline 40 & 10.33 & 10.25 & 10.78 & 9.71 & 9.67 & 8.65 & 9.05 \\
\hline
\end{tabular}


APÊNDICE D - Concentração de hemoglobina (g/dL) dos animais submetidos a diferentes tratamentos

\begin{tabular}{|c|c|c|c|c|c|c|c|}
\hline \multirow{2}{*}{ Animais } & \multicolumn{7}{|c|}{ Tempo de experimento (dias) } \\
\hline & 0 & 15 & 30 & 45 & 60 & 75 & 90 \\
\hline \multicolumn{8}{|l|}{ Grupo A } \\
\hline 1 & 9.8 & 8.8 & 8.2 & 6.2 & - & - & - \\
\hline 2 & 8.7 & 8.1 & 7.2 & 6.2 & 6.5 & 7.1 & 7.0 \\
\hline 3 & 10.3 & 9.8 & 9.5 & 8.6 & 8.8 & 8.2 & 9.0 \\
\hline 4 & 10.1 & 10.0 & 9.2 & 7.5 & 7.7 & 7.0 & 7.1 \\
\hline 5 & 11.5 & 11.0 & 11.3 & 9.9 & 8.5 & 8.7 & 8.5 \\
\hline 6 & 11.9 & 11.3 & 10.4 & 8.8 & 8.2 & 8.0 & 8.7 \\
\hline 7 & 7.5 & 5.4 & 3.9 & 2.7 & - & - & - \\
\hline 8 & 11.2 & 11.0 & 11.3 & 9.9 & 9.0 & 8.9 & 8.7 \\
\hline 9 & 10.7 & 11.3 & 10.5 & 8.7 & 8.5 & 7.6 & 8.1 \\
\hline 10 & 10.7 & 10.4 & 10.4 & 8.6 & 8.2 & 7.9 & 8.0 \\
\hline \multicolumn{8}{|l|}{ Grupo B } \\
\hline 11 & 10.2 & 9.6 & 9.3 & 8.9 & 9.0 & 9.2 & 8.9 \\
\hline 12 & 9.4 & 8.6 & 9.7 & 9.0 & 9.0 & 9.4 & 9.2 \\
\hline 13 & 9.2 & 8.4 & 8.8 & 8.1 & 8.5 & 8.0 & 7.9 \\
\hline 14 & 8.2 & 7.4 & 6.8 & 6.4 & 7.5 & 7.9 & 7.5 \\
\hline 15 & 11.3 & 10.8 & 9.7 & 10.7 & 10.5 & 10.3 & 10.9 \\
\hline 16 & 10.6 & 10.3 & 9.4 & 9.0 & 9.5 & 8.8 & 9.1 \\
\hline 17 & 10.6 & 11.1 & 11.0 & 9.1 & 9.1 & 9.5 & 9.3 \\
\hline 18 & 10.3 & 10.1 & 9.1 & 8.2 & 8.7 & 9.2 & 6.8 \\
\hline 19 & 11.4 & 9.6 & 9.3 & 9.8 & 9.1 & 9.6 & 9.9 \\
\hline 20 & 10.4 & 10.0 & 9.5 & 9.8 & 9.2 & 9.7 & 9.9 \\
\hline \multicolumn{8}{|l|}{ Grupo C } \\
\hline 21 & 9.5 & 8.7 & 9.7 & 9.2 & 8.4 & - & - \\
\hline 22 & 11.2 & 10.2 & 10.8 & 9.5 & 8.9 & 8.0 & 7.8 \\
\hline 23 & 8.3 & 7.6 & 7.5 & 6.2 & 5.9 & 5.0 & 6.1 \\
\hline 24 & 9.8 & 9.9 & 9.8 & 8.9 & 8.9 & 8.7 & 8.5 \\
\hline 25 & 8.8 & 7.4 & 8.3 & 7.9 & 6.7 & 4.0 & 3.7 \\
\hline 26 & 10.4 & 9.8 & 10.1 & 9.4 & 8.4 & 8.9 & 8.6 \\
\hline 27 & 10.2 & 8.8 & 8.5 & 9.9 & 8.4 & 9.5 & 9.5 \\
\hline 28 & 7.8 & 9.2 & 10.6 & 11.0 & 11.3 & 10.0 & 9.8 \\
\hline 29 & 10.1 & 9.6 & 10.2 & 9.1 & 8.8 & 7.6 & 8.6 \\
\hline 30 & 8.6 & 6.2 & 9.3 & 8.8 & 8.4 & - & - \\
\hline \multicolumn{8}{|l|}{ Grupo D } \\
\hline 31 & 9.7 & 9.6 & 9.4 & 8.6 & 8.6 & 7.7 & 7.8 \\
\hline 32 & 11.7 & 11.6 & 11.4 & 10.6 & 10.6 & 9.7 & 9.8 \\
\hline 33 & 7.9 & 8.3 & 7.9 & 6.6 & 6.3 & 5.5 & 5.2 \\
\hline 34 & 11.4 & 11.0 & 11.3 & 9.6 & 10.1 & 9.4 & 9.3 \\
\hline 35 & 10.8 & 9.8 & 9.8 & 8.6 & 8.1 & 7.6 & 6.8 \\
\hline 36 & 11.7 & 11.9 & 11.2 & 11.0 & 11.0 & 9.8 & 9.9 \\
\hline 37 & 9.5 & 9.8 & 9.8 & 9.1 & 9.4 & 9.6 & 10.1 \\
\hline 38 & 12.0 & 11.3 & 10.8 & 11.4 & 11.3 & 9.5 & 9.6 \\
\hline 39 & 10.6 & 10.9 & 10.4 & 9.5 & 10.2 & 9.3 & 9.4 \\
\hline 40 & 11.9 & 11.7 & 12.6 & 10.9 & 10.5 & 9.1 & 10.0 \\
\hline
\end{tabular}


APÊNDICE E - Percentual de hematócrito (\%) dos animais submetidos a diferentes tratamentos

\begin{tabular}{cccccccc}
\hline \multirow{2}{*}{ Animais } & \multicolumn{7}{c}{ Tempo de experimento (dias) } \\
\cline { 2 - 8 } Grupo A & 0 & 15 & 30 & 45 & 60 & 75 & 90 \\
1 & 30.3 & 27.0 & 24.7 & 18.1 & - & - & - \\
2 & 26.0 & 24.1 & 21.2 & 17.8 & 18.8 & 20.9 & 20.5 \\
3 & 32.7 & 30.3 & 29.1 & 26.0 & 26.7 & 24.7 & 27.4 \\
4 & 31.7 & 31.2 & 28.1 & 22.3 & 22.9 & 20.5 & 20.9 \\
5 & 34.9 & 34.0 & 35.3 & 30.5 & 25.7 & 26.4 & 25.7 \\
6 & 36.0 & 33.5 & 32.2 & 26.7 & 24.7 & 24.0 & 26.4 \\
7 & 22.0 & 16.8 & 12.5 & 8.5 & - & - & \\
8 & 37.0 & 33.7 & 35.3 & 30.5 & 27.4 & 27.1 & 26.4 \\
9 & 34.6 & 33.5 & 32.5 & 26.4 & 25.7 & 22.6 & 24.5 \\
10 & 34.6 & 33.1 & 32.2 & 26.0 & 24.7 & 23.6 & 24.0 \\
\hline Grupo B & & & & & & & \\
11 & 32.2 & 29.6 & 28.3 & 27.1 & 27.4 & 27.9 & 27.2 \\
12 & 28.3 & 25.8 & 29.8 & 27.4 & 27.4 & 28.8 & 28.1 \\
13 & 27.4 & 25.9 & 26.7 & 24.3 & 25.7 & 24.0 & 23.6 \\
14 & 25.6 & 22.4 & 19.9 & 18.5 & 22.3 & 23.6 & 22.3 \\
15 & 35.5 & 33.1 & 29.8 & 33.2 & 32.5 & 31.9 & 33.9 \\
16 & 34.1 & 32.7 & 28.8 & 27.4 & 29.1 & 26.7 & 27.7 \\
17 & 33.9 & 34.0 & 34.3 & 27.7 & 27.7 & 29.1 & 28.4 \\
18 & 32.7 & 31.7 & 27.7 & 24.7 & 26.4 & 28.1 & 19.9 \\
19 & 34.9 & 29.3 & 28.4 & 30.1 & 27.7 & 29.5 & 30.5 \\
20 & 37.9 & 31.2 & 29.1 & 30.1 & 28.1 & 29.8 & 30.5 \\
\hline Grupo C & & & & & & & \\
21 & 29.2 & 26.3 & 29.0 & 27.3 & 25.4 & - & - \\
22 & 35.0 & 31.2 & 33.6 & 29.1 & 27.1 & 24.0 & 23.3 \\
23 & 25.1 & 20.7 & 22.3 & 17.8 & 16.8 & 14.8 & 17.5 \\
24 & 30.3 & 30.7 & 30.1 & 27.1 & 27.1 & 26.4 & 25.7 \\
25 & 25.5 & 21.9 & 25.0 & 23.6 & 19.5 & 12.3 & 9.5 \\
26 & 33.1 & 30.3 & 31.2 & 28.8 & 25.3 & 27.1 & 26.0 \\
27 & 32.2 & 26.5 & 25.7 & 30.5 & 25.4 & 29.1 & 29.1 \\
28 & 23.0 & 27.4 & 32.9 & 34.3 & 35.3 & 30.8 & 30.1 \\
29 & 31.7 & 29.3 & 31.5 & 27.7 & 26.7 & 22.6 & 26.0 \\
30 & 27.0 & 19.0 & 28.4 & 26.7 & 25.4 & - & - \\
\hline Grupo D & & & & & & & \\
31 & 31.3 & 31.4 & 31.4 & 28.4 & 25.5 & 25.4 & 25.8 \\
32 & 33.3 & 33.4 & 33.4 & 30.4 & 30.5 & 27.4 & 27.8 \\
33 & 21.1 & 25.1 & 23.6 & 19.2 & 18.1 & 15.4 & 15.4 \\
34 & 34.9 & 33.0 & 35.3 & 29.5 & 31.2 & 28.8 & 28.4 \\
35 & 33.1 & 30.3 & 30.1 & 26.0 & 24.3 & 22.6 & 19.9 \\
36 & 35.4 & 36.5 & 34.9 & 34.3 & 34.3 & 30.1 & 30.5 \\
37 & 28.8 & 30.3 & 30.1 & 27.7 & 28.8 & 29.5 & 31.2 \\
38 & 36.8 & 35.5 & 33.6 & 35.6 & 35.3 & 29.1 & 29.5 \\
39 & 32.1 & 33.5 & 32.2 & 29.1 & 31.5 & 28.4 & 28.8 \\
40 & 36.3 & 35.4 & 39.7 & 33.9 & 32.5 & 27.7 & 30.8 \\
\hline & & & & & & & \\
\hline
\end{tabular}


APÊNDICE F - Concentração de proteínas totais séricas (g/dL) dos animais submetidos a diferentes tratamentos

\begin{tabular}{cccccccc}
\hline \multirow{2}{*}{ Animais } & \multicolumn{7}{c}{ Tempo de experimento (dias) } \\
\cline { 2 - 7 } Grupo A & 0 & 15 & 30 & 45 & 60 & 75 & 90 \\
1 & 6.5 & 7.1 & 6.2 & 6.8 & - & - & - \\
2 & 7.0 & 7.0 & 6.4 & 7.0 & 5.3 & 5.8 & 5.9 \\
3 & 7.7 & 8.2 & 7.4 & 8.1 & 7.6 & 6.1 & 7.1 \\
4 & 7.5 & 8.3 & 7.7 & 7.7 & 6.4 & 7.1 & 7.7 \\
5 & 7.6 & 7.9 & 7.3 & 6.5 & 4.3 & 6.0 & 6.7 \\
6 & 8.1 & 7.9 & 6.7 & 7.0 & 6.7 & 6.2 & 6.2 \\
7 & 8.0 & 7.3 & 6.8 & 5.7 & - & - & - \\
8 & 7.5 & 8.0 & 7.7 & 7.4 & 5.6 & 6.5 & 6.7 \\
9 & 7.1 & 5.9 & 6.6 & 5.5 & 5.5 & 5.8 & 5.6 \\
10 & 7.0 & 7.7 & 6.8 & 7.2 & 7.6 & 6.1 & 6.2 \\
\hline Grupo B & & & & & & & \\
11 & 7.5 & 7.8 & 7.0 & 7.0 & 7.1 & 6.0 & 6.5 \\
12 & 7.4 & 7.7 & 7.1 & 6.3 & 7.9 & 6.5 & 6.9 \\
13 & 7.1 & 7.2 & 6.5 & 6.9 & 6.9 & 4.6 & 4.7 \\
14 & 8.1 & 8.2 & 7.6 & 8.3 & 8.0 & 6.7 & 6.8 \\
15 & 8.1 & 7.8 & 7.1 & 6.1 & 7.3 & 6.0 & 8.0 \\
16 & 6.5 & 7.0 & 6.3 & 7.3 & 6.8 & 5.9 & 5.5 \\
17 & 5.9 & 6.4 & 5.9 & 6.2 & 6.6 & 5.6 & 7.1 \\
18 & 8.8 & 8.9 & 7.6 & 7.1 & 7.6 & 6.6 & 8.3 \\
19 & 7.2 & 7.3 & 6.6 & 7.1 & 6.9 & 6.5 & 6.8 \\
20 & 7.3 & 8.7 & 7.6 & 7.5 & 7.4 & 7.5 & 5.5 \\
\hline Grupo C & & & & & & & \\
21 & 7.0 & 7.5 & 7.6 & 7.5 & 6.8 & - & - \\
22 & 6.6 & 7.2 & 6.6 & 7.6 & 6.0 & 4.5 & 5.4 \\
23 & 6.9 & 8.2 & 8.2 & 7.8 & 4.3 & 6.1 & 7.2 \\
24 & 9.0 & 8.5 & 8.6 & 7.2 & 6.0 & 7.2 & 7.2 \\
25 & 6.5 & 6.7 & 6.0 & 7.6 & 6.3 & 4.1 & 5.0 \\
26 & 6.3 & 6.4 & 6.0 & 6.9 & 6.2 & 5.8 & 6.2 \\
27 & 7.2 & 7.2 & 7.2 & 7.5 & 8.0 & 7.4 & 5.4 \\
28 & 8.1 & 8.6 & 7.7 & 7.2 & 6.8 & 6.3 & 7.3 \\
29 & 7.7 & 7.5 & 7.2 & 7.4 & 7.4 & 6.0 & 7.2 \\
30 & 6.0 & 6.3 & 6.8 & 7.3 & 6.0 & - & - \\
\hline Grupo D & & & & & & & \\
31 & 7.6 & 8.0 & 7.5 & 7.9 & 7.2 & 6.8 & 7.0 \\
32 & 7.2 & 8.0 & 7.1 & 7.2 & 6.9 & 6.3 & 6.8 \\
33 & 8.0 & 8.6 & 7.7 & 6.8 & 7.6 & 6.9 & 6.3 \\
34 & 7.6 & 8.3 & 7.5 & 8.1 & 7.6 & 5.7 & 7.0 \\
35 & 7.2 & 8.7 & 8.3 & 8.7 & 6.5 & 7.9 & 8.6 \\
36 & 6.9 & 7.0 & 6.9 & 7.1 & 7.3 & 7.0 & 7.0 \\
37 & 7.3 & 7.3 & 6.9 & 7.1 & 7.8 & 5.7 & 5.0 \\
38 & 7.8 & 7.6 & 7.2 & 7.8 & 6.5 & 5.6 & 7.1 \\
39 & 6.9 & 8.4 & 6.3 & 7.1 & 6.7 & 6.5 & 6.9 \\
40 & 7.7 & 8.6 & 7.7 & 7.8 & 6.1 & 6.6 & 7.0 \\
\hline & & & & & & & \\
\hline
\end{tabular}


APÊNDICE G - Concentração de albumina sérica (g/dL) dos animais submetidos a diferentes tratamentos

\begin{tabular}{|c|c|c|c|c|c|c|c|}
\hline \multirow{2}{*}{ Animais } & \multicolumn{7}{|c|}{ Tempo de experimento (dias) } \\
\hline & 0 & 15 & 30 & 45 & 60 & 75 & 90 \\
\hline \multicolumn{8}{|l|}{ Grupo A } \\
\hline 1 & 3.5 & 3.5 & 3.4 & 3.2 & - & - & - \\
\hline 2 & 3.3 & 3.2 & 3.3 & 2.9 & 2.5 & 2.5 & 2.2 \\
\hline 3 & 3.4 & 3.3 & 3.6 & 3.4 & 3.3 & 2.8 & 3.1 \\
\hline 4 & 3.4 & 3.0 & 2.8 & 2.7 & 2.5 & 2.4 & 2.6 \\
\hline 5 & 3.6 & 3.6 & 4.1 & 3.8 & 2.2 & 3.3 & 3.2 \\
\hline 6 & 3.6 & 3.5 & 3.7 & 3.9 & 3.4 & 3.1 & 2.8 \\
\hline 7 & 3.5 & 3.3 & 3.3 & 3.1 & - & - & - \\
\hline 8 & 3.5 & 3.3 & 3.6 & 3.6 & 2.4 & 3.0 & 2.8 \\
\hline 9 & 3.4 & 3.0 & 3.5 & 3.3 & 3.0 & 2.4 & 2.4 \\
\hline 10 & 3.4 & 3.2 & 3.5 & 3.5 & 3.3 & 2.9 & 3.0 \\
\hline \multicolumn{8}{|l|}{ Grupo B } \\
\hline 11 & 3.5 & 3.5 & 3.3 & 3.5 & 3.1 & 3.0 & 2.6 \\
\hline 12 & 3.5 & 3.1 & 3.5 & 3.6 & 3.4 & 2.9 & 2.9 \\
\hline 13 & 3.3 & 3.1 & 3.0 & 3.2 & 2.9 & 1.9 & 1.8 \\
\hline 14 & 3.2 & 3.1 & 3.3 & 3.3 & 3.2 & 2.5 & 2.5 \\
\hline 15 & 3.5 & 3.5 & 3.5 & 3.6 & 3.4 & 2.6 & 3.0 \\
\hline 16 & 3.7 & 3.6 & 3.8 & 3.9 & 3.3 & 2.6 & 2.2 \\
\hline 17 & 3.3 & 3.3 & 3.5 & 3.3 & 3.2 & 2.5 & 2.7 \\
\hline 18 & 3.1 & 3.3 & 3.1 & 3.3 & 2.8 & 3.1 & 3.7 \\
\hline 19 & 3.3 & 3.1 & 3.3 & 3.4 & 3.2 & 2.9 & 2.9 \\
\hline 20 & 3.4 & 3.2 & 3.6 & 3.8 & 3.5 & 3.2 & 2.2 \\
\hline \multicolumn{8}{|l|}{ Grupo C } \\
\hline 21 & 3.0 & 3.2 & 3.5 & 3.4 & 3.0 & - & - \\
\hline 22 & 3.5 & 3.3 & 3.9 & 3.6 & 3.1 & 2.2 & 2.5 \\
\hline 23 & 2.6 & 2.9 & 3.0 & 2.9 & 2.5 & 2.1 & 2.3 \\
\hline 24 & 3.3 & 3.1 & 3.3 & 2.7 & 2.2 & 2.5 & 2.9 \\
\hline 25 & 3.2 & 2.7 & 3.3 & 3.1 & 2.9 & 1.7 & 2.0 \\
\hline 26 & 3.2 & 3.2 & 3.5 & 3.2 & 2.7 & 2.3 & 2.9 \\
\hline 27 & 2.7 & 2.7 & 2.8 & 3.5 & 3.2 & 3.0 & 2.5 \\
\hline 28 & 3.7 & 4.0 & 4.2 & 4.0 & 3.5 & 3.0 & 3.0 \\
\hline 29 & 3.1 & 3.4 & 3.3 & 3.3 & 2.8 & 2.6 & 3.0 \\
\hline 30 & 2.2 & 2.5 & 3.3 & 3.2 & 2.8 & - & - \\
\hline \multicolumn{8}{|l|}{ Grupo D } \\
\hline 31 & 3.3 & 3.5 & 3.6 & 3.8 & 3.1 & 2.8 & 2.7 \\
\hline 32 & 3.0 & 3.3 & 3.4 & 3.4 & 2.7 & 2.4 & 2.5 \\
\hline 33 & 2.7 & 3.0 & 3.0 & 2.9 & 2.7 & 2.1 & 2.1 \\
\hline 34 & 3.4 & 3.8 & 3.7 & 3.7 & 3.4 & 2.5 & 3.1 \\
\hline 35 & 3.2 & 3.5 & 3.9 & 3.7 & 2.5 & 3.2 & 3.2 \\
\hline 36 & 3.4 & 3.4 & 3.8 & 3.7 & 3.5 & 2.0 & 1.9 \\
\hline 37 & 3.0 & 3.2 & 3.4 & 3.6 & 3.4 & 2.8 & 2.1 \\
\hline 38 & 3.2 & 3.3 & 3.4 & 3.7 & 2.7 & 2.6 & 3.4 \\
\hline 39 & 3.3 & 3.3 & 3.2 & 3.4 & 2.3 & 2.9 & 2.1 \\
\hline 40 & 3.2 & 3.3 & 3.7 & 3.7 & 2.4 & 2.8 & 3.0 \\
\hline
\end{tabular}


APÊNDICE H - Concentração de globulina sérica (g/dL) dos animais submetidos a diferentes tratamentos

\begin{tabular}{|c|c|c|c|c|c|c|c|}
\hline \multirow{2}{*}{ Animais } & \multicolumn{7}{|c|}{ Tempo de experimento (dias) } \\
\hline & 0 & 15 & 30 & 45 & 60 & 75 & 90 \\
\hline \multicolumn{8}{|l|}{ Grupo A } \\
\hline 1 & 3.0 & 3.6 & 2.8 & 3.6 & - & - & - \\
\hline 2 & 3.7 & 3.8 & 3.1 & 4.1 & 2.8 & 3.3 & 3.7 \\
\hline 3 & 4.3 & 4.9 & 3.8 & 4.7 & 4.3 & 3.3 & 4.0 \\
\hline 4 & 4.1 & 5.3 & 4.9 & 5.0 & 3.9 & 4.7 & 5.1 \\
\hline 5 & 4.0 & 4.3 & 3.2 & 2.7 & 2.1 & 2.7 & 3.5 \\
\hline 6 & 4.5 & 4.4 & 3.0 & 3.1 & 3.3 & 3.1 & 3.4 \\
\hline 7 & 4.5 & 4.0 & 3.5 & 2.6 & - & - & - \\
\hline 8 & 4.0 & 4.7 & 4.1 & 3.8 & 3.2 & 3.5 & 3.9 \\
\hline 9 & 3.7 & 2.9 & 3.1 & 2.2 & 2.5 & 3.4 & 3.2 \\
\hline 10 & 3.6 & 4.5 & 3.3 & 3.7 & 4.3 & 3.2 & 3.2 \\
\hline \multicolumn{8}{|l|}{ Grupo B } \\
\hline 11 & 4.0 & 4.3 & 3.7 & 3.5 & 4.0 & 3.0 & 3.9 \\
\hline 12 & 3.9 & 4.6 & 3.6 & 2.7 & 4.5 & 3.6 & 4.0 \\
\hline 13 & 3.8 & 4.1 & 3.5 & 3.7 & 4.0 & 2.7 & 2.9 \\
\hline 14 & 4.9 & 5.1 & 4.3 & 5.0 & 4.8 & 4.2 & 4.3 \\
\hline 15 & 4.6 & 4.3 & 3.6 & 2.5 & 3.9 & 3.4 & 5.0 \\
\hline 16 & 2.8 & 3.4 & 2.5 & 3.4 & 3.5 & 3.3 & 3.3 \\
\hline 17 & 2.6 & 3.1 & 2.4 & 2.9 & 3.4 & 3.1 & 4.4 \\
\hline 18 & 5.7 & 5.6 & 4.5 & 3.8 & 4.8 & 3.5 & 4.6 \\
\hline 19 & 3.9 & 4.2 & 3.3 & 3.7 & 3.7 & 3.6 & 3.9 \\
\hline 20 & 3.9 & 5.5 & 4.0 & 3.7 & 3.9 & 4.3 & 3.3 \\
\hline \multicolumn{8}{|l|}{ Grupo C } \\
\hline 21 & 4.0 & 4.3 & 4.1 & 4.1 & 3.8 & - & - \\
\hline 22 & 3.1 & 3.9 & 2.7 & 4.0 & 2.9 & 2.3 & 2.9 \\
\hline 23 & 4.3 & 5.3 & 5.2 & 4.9 & 1.8 & 4.0 & 4.9 \\
\hline 24 & 5.7 & 5.4 & 5.3 & 4.5 & 3.8 & 4.7 & 4.3 \\
\hline 25 & 3.3 & 4.0 & 2.7 & 4.5 & 3.4 & 2.4 & 3.0 \\
\hline 26 & 3.1 & 3.2 & 2.5 & 3.7 & 3.5 & 3.5 & 3.3 \\
\hline 27 & 4.5 & 4.5 & 4.4 & 4.0 & 4.8 & 4.4 & 2.9 \\
\hline 28 & 4.4 & 4.6 & 3.5 & 3.2 & 3.3 & 3.3 & 4.3 \\
\hline 29 & 4.6 & 4.1 & 3.9 & 4.1 & 4.6 & 3.4 & 4.2 \\
\hline 30 & 3.8 & 3.8 & 3.5 & 4.1 & 3.2 & - & - \\
\hline \multicolumn{8}{|l|}{ Grupo D } \\
\hline 31 & 4.3 & 4.5 & 3.9 & 4.1 & 4.1 & 4.0 & 4.3 \\
\hline 32 & 4.2 & 4.7 & 3.7 & 3.8 & 4.2 & 3.9 & 4.3 \\
\hline 33 & 5.3 & 5.6 & 4.7 & 3.9 & 4.9 & 4.8 & 4.2 \\
\hline 34 & 4.2 & 4.5 & 3.8 & 4.4 & 4.2 & 3.2 & 3.9 \\
\hline 35 & 4.0 & 5.2 & 4.4 & 5.0 & 4.0 & 4.7 & 5.4 \\
\hline 36 & 3.5 & 3.6 & 3.1 & 3.4 & 3.8 & 5.0 & 5.1 \\
\hline 37 & 4.3 & 4.1 & 3.5 & 3.5 & 4.4 & 2.9 & 2.9 \\
\hline 38 & 4.6 & 4.3 & 3.8 & 4.1 & 3.8 & 3.0 & 3.7 \\
\hline 39 & 3.6 & 5.1 & 3.1 & 3.7 & 4.4 & 3.6 & 4.8 \\
\hline 40 & 4.5 & 5.3 & 4.0 & 4.1 & 3.7 & 3.8 & 4.0 \\
\hline
\end{tabular}


APÊNDICE I - Concentração de ferro sérico ( $\mu \mathrm{g} / \mathrm{dL}$ ) dos animais submetidos a diferentes tratamentos

\begin{tabular}{|c|c|c|c|c|c|c|c|}
\hline \multirow{2}{*}{ Animais } & \multicolumn{7}{|c|}{ Tempo de experimento } \\
\hline & 0 & 15 & 30 & 45 & 60 & 75 & 90 \\
\hline \multicolumn{8}{|l|}{ Grupo A } \\
\hline 1 & 124 & 112 & 99 & 54 & - & - & - \\
\hline 2 & 120 & 179 & 124 & 61 & 84 & 118 & 68 \\
\hline 3 & 152 & 143 & 168 & 162 & 124 & 111 & 99 \\
\hline 4 & 76 & 110 & 118 & 103 & 105 & 84 & 72 \\
\hline 5 & 177 & 193 & 193 & 184 & 126 & 139 & 133 \\
\hline 6 & 112 & 117 & 151 & 130 & 56 & 80 & 88 \\
\hline 7 & 108 & 22 & 24 & 21 & - & - & - \\
\hline 8 & 125 & 119 & 153 & 164 & 151 & 96 & 95 \\
\hline 9 & 92 & 61 & 86 & 164 & 101 & 139 & 106 \\
\hline 10 & 141 & 120 & 164 & 153 & 110 & 106 & 118 \\
\hline \multicolumn{8}{|l|}{ Grupo B } \\
\hline 11 & 120 & 145 & 175 & 154 & 130 & 135 & 140 \\
\hline 12 & 147 & 174 & 206 & 206 & 176 & 137 & 159 \\
\hline 13 & 65 & 71 & 100 & 82 & 89 & 64 & 59 \\
\hline 14 & 144 & 158 & 167 & 164 & 107 & 137 & 101 \\
\hline 15 & 92 & 140 & 170 & 176 & 200 & 166 & 207 \\
\hline 16 & 124 & 146 & 148 & 97 & 92 & 119 & 144 \\
\hline 17 & 138 & 147 & 143 & 174 & 155 & 157 & 180 \\
\hline 18 & 107 & 138 & 208 & 159 & 70 & 111 & 70 \\
\hline 19 & 124 & 126 & 251 & 198 & 207 & 187 & 202 \\
\hline 20 & 133 & 186 & 172 & 143 & 122 & 110 & 99 \\
\hline \multicolumn{8}{|l|}{ Grupo C } \\
\hline 21 & 120 & 115 & 199 & 201 & 177 & - & - \\
\hline 22 & 94 & 116 & 167 & 153 & 118 & 83 & 62 \\
\hline 23 & 60 & 86 & 104 & 64 & 67 & 64 & 39 \\
\hline 24 & 122 & 95 & 125 & 135 & 116 & 113 & 80 \\
\hline 25 & 70 & 47 & 45 & 110 & 125 & 73 & 51 \\
\hline 26 & 143 & 135 & 173 & 241 & 209 & 175 & 164 \\
\hline 27 & 122 & 114 & 240 & 158 & 132 & 116 & 62 \\
\hline 28 & 245 & 178 & 206 & 231 & 160 & 118 & 154 \\
\hline 29 & 124 & 175 & 201 & 195 & 167 & 124 & 125 \\
\hline 30 & 61 & 73 & 118 & 121 & 97 & - & - \\
\hline \multicolumn{8}{|l|}{ Grupo D } \\
\hline 31 & 130 & 125 & 160 & 160 & 151 & 125 & 120 \\
\hline 32 & 110 & 105 & 140 & 150 & 132 & 120 & 115 \\
\hline 33 & 70 & 85 & 169 & 107 & 186 & 156 & 111 \\
\hline 34 & 101 & 120 & 146 & 183 & 189 & 118 & 156 \\
\hline 35 & 158 & 101 & 133 & 58 & 97 & 106 & 133 \\
\hline 36 & 93 & 129 & 173 & 196 & 150 & 111 & 79 \\
\hline 37 & 159 & 106 & 156 & 276 & 146 & 117 & 85 \\
\hline 38 & 148 & 152 & 110 & 167 & 139 & 143 & 166 \\
\hline 39 & 154 & 95 & 142 & 168 & 116 & 126 & 92 \\
\hline 40 & 86 & 113 & 160 & 103 & 94 & 103 & 113 \\
\hline
\end{tabular}

